San Jose State University

SJSU ScholarWorks

Master's Theses

Master's Theses and Graduate Research

Summer 2017

\title{
A Multi-method Study of Metamorphism and Fluid Flow During Contact Metamorphism of the May Lake Interpluton Screen, Yosemite National Park, California
}

Susan Marie Scudder

San Jose State University

Follow this and additional works at: https://scholarworks.sjsu.edu/etd_theses

\section{Recommended Citation}

Scudder, Susan Marie, "A Multi-method Study of Metamorphism and Fluid Flow During Contact Metamorphism of the May Lake Interpluton Screen, Yosemite National Park, California" (2017). Master's Theses. 4860.

DOI: https://doi.org/10.31979/etd.6d9g-f9j2

https://scholarworks.sjsu.edu/etd_theses/4860

This Thesis is brought to you for free and open access by the Master's Theses and Graduate Research at SJSU ScholarWorks. It has been accepted for inclusion in Master's Theses by an authorized administrator of SJSU ScholarWorks. For more information, please contact scholarworks@sjsu.edu. 


\title{
A MULTI-METHOD STUDY OF METAMORPHISM AND FLUID FLOW DURING CONTACT METAMORPHISM OF THE MAY LAKE INTERPLUTON SCREEN, YOSEMITE NATIONAL PARK, CALIFORNIA
}

\author{
A Thesis \\ Presented to \\ The Faculty of the Department of Geology \\ San José State University \\ In Partial Fulfillment \\ of the Requirements for the Degree \\ Master of Science
}

by

Susan Marie Scudder

August 2017 
(C) 2017

Susan Marie Scudder

ALL RIGHTS RESERVED 
The Designated Thesis Committee Approves the Thesis Titled

\author{
A MULTI-METHOD STUDY OF METAMORPHISM AND FLUID FLOW DURING \\ CONTACT METAMORPHISM OF THE MAY LAKE INTERPLUTON SCREEN, \\ YOSEMITE NATIONAL PARK, CALIFORNIA \\ by \\ Susan Marie Scudder \\ APPROVED FOR THE DEPARTMENT OF GEOLOGY
}

SAN JOSÉ STATE UNIVERSITY

August 2017
Dr. Ellen Metzger
Department of Geology
Dr. Robert Miller
Department of Geology
Dr. Jonathan Miller
Department of Geology 


\section{ABSTRACT \\ A MULTI-METHOD STUDY OF METAMORPHISM AND FLUID FLOW DURING CONTACT METAMORPHISM OF THE MAY LAKE INTERPLUTON SCREEN, YOSEMITE NATIONAL PARK, CALIFORNIA}

by Susan Marie Scudder

The May Lake interpluton screen is a $4 \mathrm{~km}$ long, $\sim 0.5 \mathrm{~km}$ wide swath of metamorphic rock cropping out between plutons of the $\sim 103$ Ma Yosemite Valley Intrusive Suite and the 93-85 Ma Tuolumne Intrusive Suite in Yosemite National Park, California. Metasomatic alteration and recrystallization due to contact metamorphism and fluid infiltration resulted from the emplacement of the Cretaceous plutons. Mineral assemblages are consistent with metamorphism to hornblende-hornfels and amphibolite facies. The presence of sillimanite-bearing metapelite and more Mg-rich clinopyroxene in calc-silicate assemblages of the northeast section of the screen than the southwest suggest higher grade metamorphism was experienced to the northeast. Pseudosection diagrams created from whole rock chemical analyses of three metapelite rocks also indicate higher temperatures in the northeastern section of the screen with minimum temperatures estimated from $\sim 540-617^{\circ} \mathrm{C}$. Based on petrographic analysis of andalusiteand sillimanite-bearing metapelite, it is likely that the screen experienced two stages of contact metamorphism: relatively lower temperature metamorphism during intrusion of the Yosemite Valley Intrusive Suite followed by relatively higher temperature contact metamorphism during intrusion of the more mafic Tuolumne Intrusive Suite. Stable isotope data suggest that rock permeability and preexisting structures were the strongest factors controlling fluid infiltration through the contact aureole. 


\section{ACKNOWLEDGMENTS}

Firstly, I would like to thank my advisor, Ellen Metzger, for her insights, patience, and wisdom, and for sharing my excitement for these beautiful and complicated metamorphic rocks. I am very grateful to Robert Miller and Jonathan Miller as well for their detailed feedback and advanced perspectives on field work in Yosemite National Park. I would also like to thank Heather Bleick at the USGS and Nick Botto and Sarah Roeske at UC Davis for their assistance with electron microprobe analyses at the Menlo Park, CA, and Davis, CA, facilities, and Peter Blisniuk at the Stanford University Biogeochemical lab for the stable isotope analyses. Lastly, I am very grateful to my husband, Chris Scudder, for his indispensable field assistance and constant support, especially during the lengthy writing process. This research was funded by a 2011 San

Jose State University Research, Scholarship, and Creativity Activity grant and a 2012 GSA student grant. 


\section{TABLE OF CONTENTS}

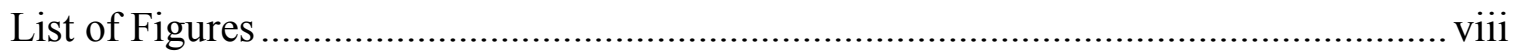

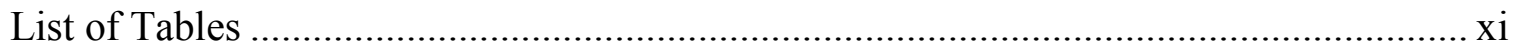

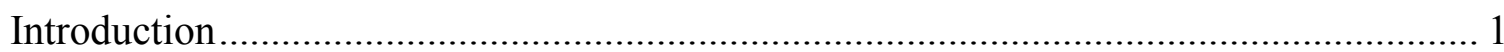

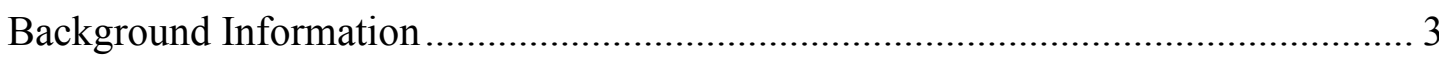

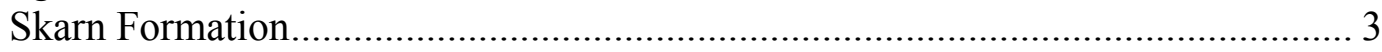

Stable Isotopes as Evidence of Fluid Migration and Metasomatism....................... 5

Previous Studies of Metasomatism in Contact Aureoles ..................................... 10

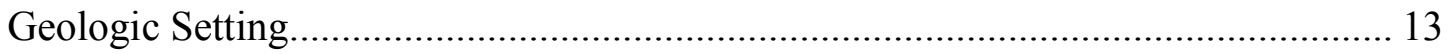

Previous Studies at May Lake.............................................................................. 16

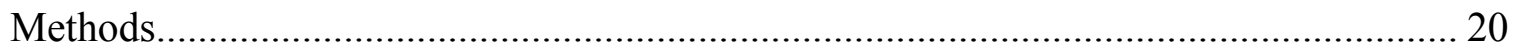

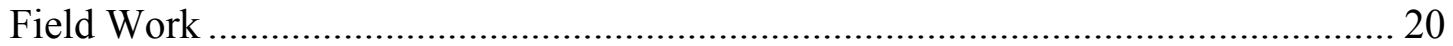

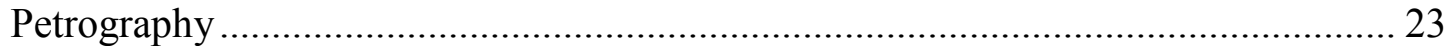

Electron Microprobe Analysis ............................................................................. 23

Whole Rock Geochemistry ……………………………………………………. 25

Stable Isotope Mineral Analysis ........................................................................... 25

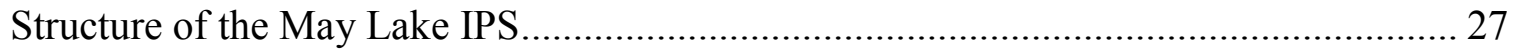

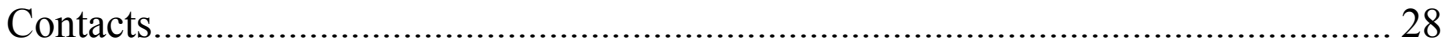

May Lake IPS Contacts with Surrounding Plutons ............................................ 28

Contacts between Metasedimentary Units .............................................................. 31

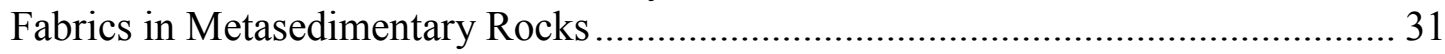

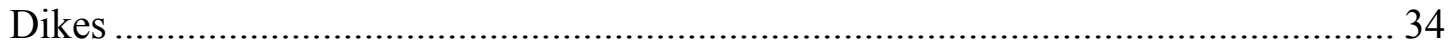

Petrography and Mineral Chemistry ………………….......................................... 36

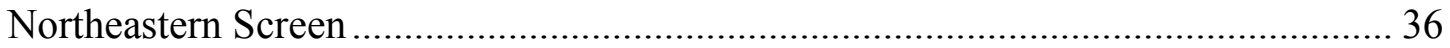

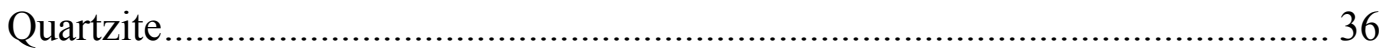

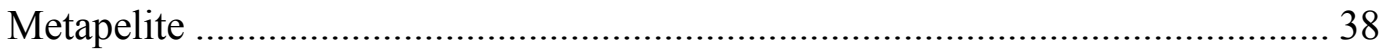

Calc-Silicate Hornfels ................................................................................ 40

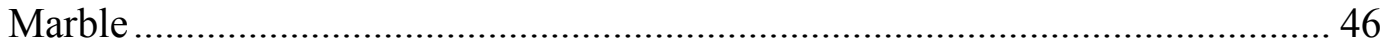

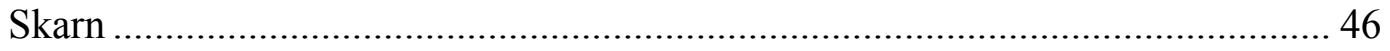

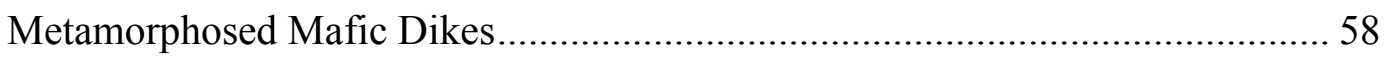

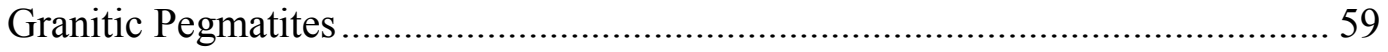

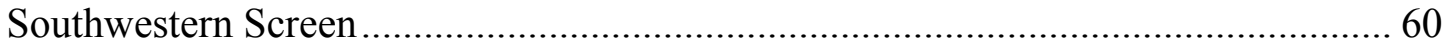

Silicic and Aluminous Metasedimentary Units .................................................. 60

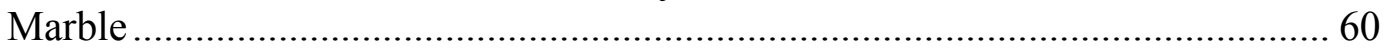

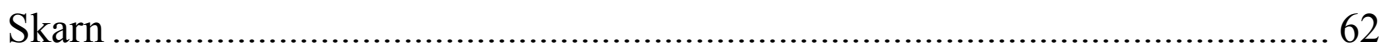

Metamorphosed Mafic Dikes.............................................................................. 64

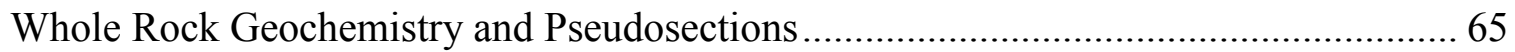

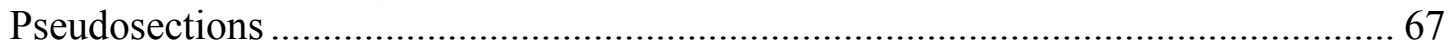




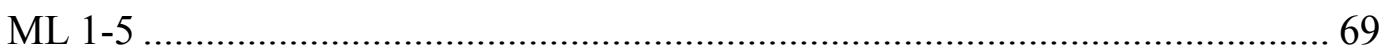

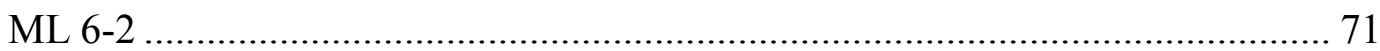

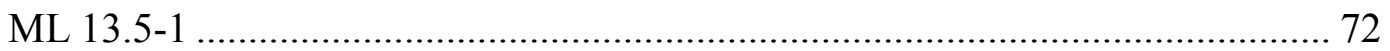

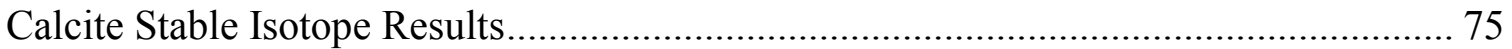

Stable Isotope Results from the Northeastern Screen ............................................ 75

Stable Isotope Results from the Southwestern Screen............................................. 79

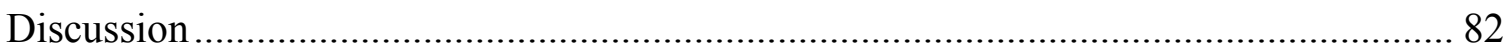

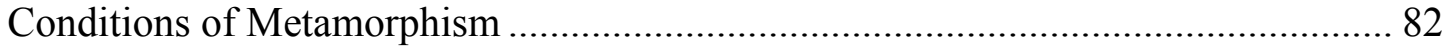

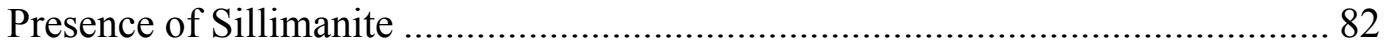

Titanium in Biotite Thermometry ........................................................... 83

$\mathrm{Mg} / \mathrm{Fe}$ Ratios in Calc-Silicate Hornfels Clinopyroxenes.................................. 84

Mineral Chemistry Zoning in 3-cm Garnet at ML 28 ..................................... 84

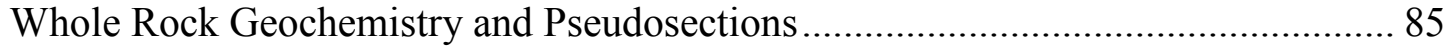

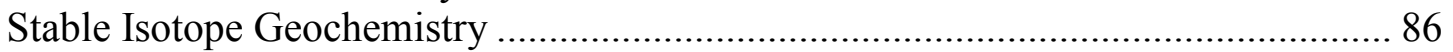

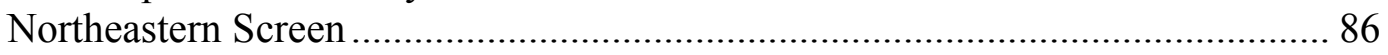

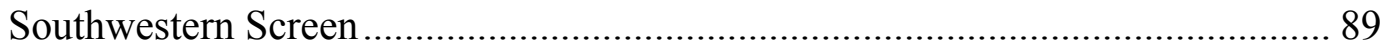

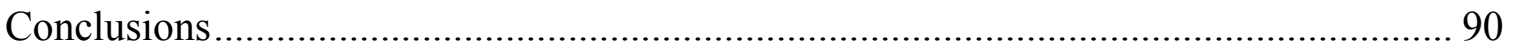

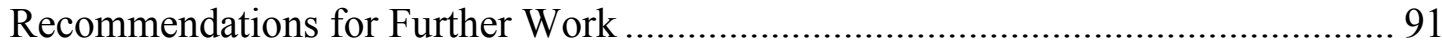

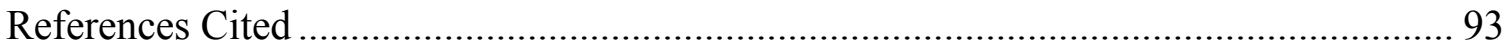

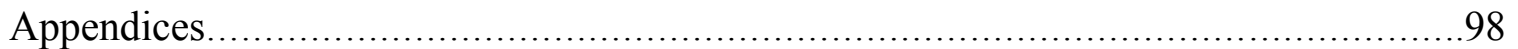

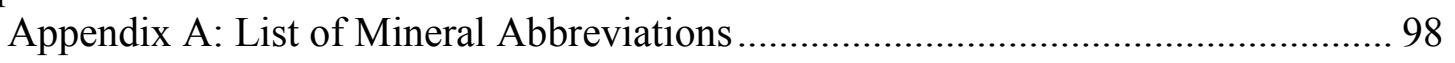

Appendix B: Electron Microprobe Mineral Chemistry ........................................ 100

Appendix C: List of Pseudosection Mineral Abbreviations .................................. 113 


\section{LIST OF FIGURES}

Figure 1. Variations in oxygen isotope ratios for magmas, rocks, and other earth reservoirs, modified from Bindeman (2008).

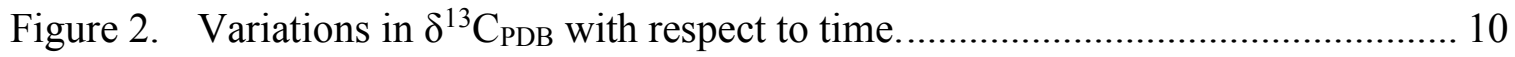

Figure 3. Location map, modified from Mills (2007) ............................................. 14

Figure 4. Geologic map of the May Lake IPS, modified after Memeti, et al., 2010 . 15

Figure 5. Map showing units of the Snow Lake block and possible location of the Mojave-Snow Lake fault, edited from Memeti et al. (2010). 18

Figure 6. Station locations (shown by black diamonds) from the northeastern section of the May Lake IPS.

Figure 7. Station locations (shown by black diamonds) from the southwestern section of the May Lake IPS.

Figure 8. IPS-TIS contact at station ML 36, looking northwest.

Figure 9. Metapelitic xenolith with reaction rim, within the Glen Aulin granodiorite at station ML 28.

Figure 10. Calc-silicate hornfels xenolith within Glen Aulin endoskarn: sample

ML 28-6.

Figure 11. Brecciated granitic rock at the northeastern tip of the May Lake IPS, $\sim 10 \mathrm{~m}$ north of station ML 40, looking northeast approximately along the YVIS-TIS contact. 30

Figure 12. Examples of metapelitic rock structures. 32

Figure 13. Stereoplots of (A) pluton-IPS contacts, and (B) foliation within the northeastern screen. 33

Figure 14. Stereoplot of foliation within the southwestern screen. 33

Figure 15. Foliation in marble from station ML 58 oriented $335^{\circ}, \sim 90^{\circ} \mathrm{NE}$. 34

Figure 16. Thin metamorphosed mafic dike in southwestern screen with $18 \mathrm{~cm}$ field book for scale. 
Figure 17. Photomicrograph of quartzite sample ML 1-3A in cross polarized light. 38

Figure 18. Calc-silicate and marble in northeastern screen. 40

Figure 19. $\mathrm{Mg}^{2+}$ atoms per formula unit (apfu) versus $\mathrm{Fe}^{2+}$ apfu for calc-silicate hornfels clinopyroxenes. 43

Figure 20. Weight percent $\mathrm{TiO}_{2}$ versus weight percent $\mathrm{SiO}_{2}$ in calc-silicate hornfels clinopyroxenes. 43

Figure 21. Calc-silicate hornfels garnet end-member composition. 44

Figure 22. Calc-silicate hornfels plagioclase feldspar end member compositions. 45

Figure 23. Photomicrographs of sample ML 21-3 in plane polarized (A) and cross polarized (B) light.

Figure 24. Skarn minerals from station ML 28 .................................................... 50

Figure 25. Alteration of granodiorite to endoskarn at ML 28 contact. ......................... 51

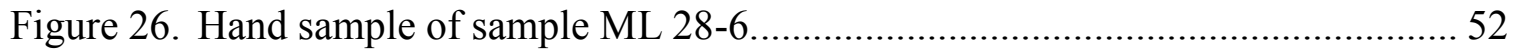

Figure 27. Tetrahedral site $\mathrm{Al}$ atoms per formula unit (apfu) versus $\mathrm{Na}+\mathrm{K}$ apfu in hornblende from station ML 28. 53

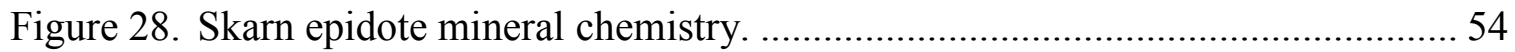

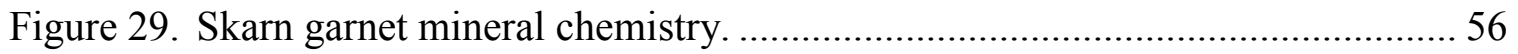

Figure 30. Back-scattered electron images of outer rim of zoned 3-cm diameter garnet from exoskarn sample ML 28-2 ................................................. 57

Figure 31. $\mathrm{Fe}^{3+}$ and $\mathrm{Al}$ atoms per formula unit (apfu) from core to rim of zoned 3cm diameter skarn garnet from sample ML 28-2 ..................................... 58

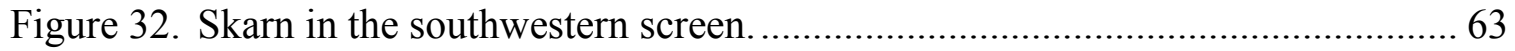

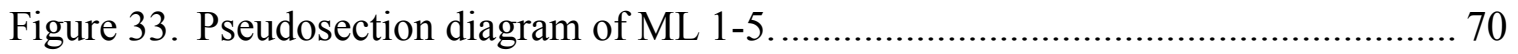

Figure 34. Pseudosection diagram of metapelite sample ML 6-2 ............................... 72

Figure 35. Pseudosection diagram of metapelite sample ML 13.5-1.......................... 73 
Figure 36. Stable isotope sample locations (black dots) from northeastern screen of May Lake IPS.

Figure 37. Stable isotope sample locations (black dots) from southwestern screen of May Lake IPS.

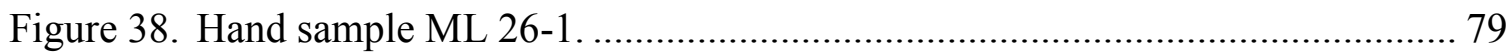

Figure 39. Field photograph of sample T2-2 marble and sample T2-1 thick metamorphosed mafic dike.

Figure 40. 4-cm thick dike extending through marble at station ML 60a for $\sim 28$

$\mathrm{m}$.

Figure 41. Calcite $\delta^{13} \mathrm{C}_{\mathrm{PDB}}$ versus $\delta^{18} \mathrm{O}_{\text {vSMOW, }}$ in parts per million (\%o) of analyzed samples from the May Lake IPS. 


\section{LIST OF TABLES}

Table 1. Representative quartzite mineralogy and sample descriptions. .................... 37

Table 2. Representative metapelite mineralogy...................................................... 39

Table 3. Select calc-silicate hornfels mineral assemblages. .................................. 41

Table 4. Descriptions of skarn samples from the northeastern screen......................... 48

Table 5. Mineralogy of station ML 28 skarn formation. ....................................... 49

Table 6. Metamorphosed mafic dike petrographic descriptions. ................................ 59

Table 7. Rock descriptions and mineral assemblages for southwestern marble

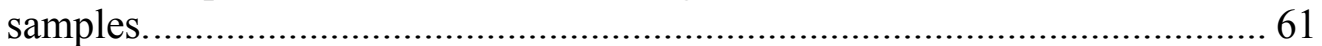

Table 8. Sample description and mineralogy of endoskarn sample T3-1 and

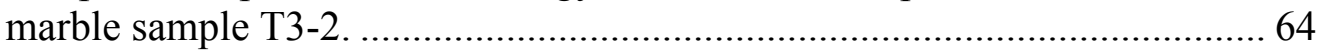

Table 9. Sample descriptions and mineral assemblages of samples T2-1 and T2-

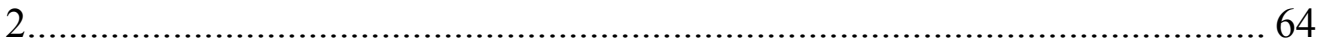

Table 10. Major elements (in weight \% oxide) of May Lake metapelite samples. ........ 66

Table 11. Comprehensive list of solution models and references used for pseudosection calculation.

Table 12. Calcite $\delta^{18} \mathrm{O}_{\text {vsmow }} \%$, $\delta^{13} \mathrm{C}_{\mathrm{PDB}} \%$, and analytical error values of May Lake IPS samples. 


\section{INTRODUCTION}

Metasedimentary rocks preserved as screens and roof pendants adjacent to plutons contain extensive information about pre- and syn-intrusion physical and chemical conditions. The interaction of chemically exotic fluid with these metasedimentary rocks during metamorphism may cause various metasomatic reactions to occur, resulting in complex mineralogy and skarn formation. Studies of these screens and pendants provide information about the tectonic history of the region prior to and during contact metamorphism, emplacement mechanisms active during the formation of plutons, and associated metamorphic conditions and processes.

The May Lake interpluton screen (IPS) is a relatively small, metamorphosed miogeoclinal wedge of variable lithologies situated between plutons of the Tuolumne Intrusive Suite (TIS) and the Yosemite Valley Intrusive Suite (YVIS) of Yosemite National Park, California. This area is ideal for a multi-method geochemical study of metamorphism for two reasons. Firstly, an extensive modern geochemical study focusing on metamorphic mineral equilibria has not previously been performed on these rocks. The field area provides an opportunity to apply modern geochemical techniques in tandem with standard methods of metamorphic petrology. Secondly, chemical reactions and stable isotopic values determined for this relatively small metamorphic screen may be of interest for comparison with the results of magmatic fluid migration and fluid infiltration studies performed elsewhere in screens and pendants of the Sierra Nevada and other batholiths. 
This study focuses on the two fundamental processes occurring in contact aureoles, metamorphism and fluid flow, and endeavors to answer the following questions:

1) What were the physical and chemical conditions of contact metamorphism within the May Lake IPS? Are there textural relationships, specific mineral assemblages, or solid-solution mineral equilibria present that could constrain metamorphic conditions? What prograde and retrograde metamorphic reactions characterized the pressuretemperature-time path for these rocks?

2) What source, composition, and amount of fluid interacted with these rocks? What isotopic signatures may be used to identify the fluid as magmatic, metamorphic, or meteoric? Can we determine its chemical composition? From where did it originate? How much fluid interacted with these rocks? How did it propagate and were there any structural constraints on fluid flow?

3) How did the metasomatic fluid interact with the metasediments to form the complex skarn mineralogy? What do mineral zoning and inclusions show about how mineral reactions progressed? Are there changes in the apparent fluid-rock interaction with distance from contacts?

Field observations, petrography, mineral chemistry, whole rock chemistry, and stable isotope analytical results are combined to describe the metamorphic and metasomatic processes that formed the mineral assemblages in this screen. 


\section{Background Information}

Fluids play a critical role in metamorphism. They act as a catalyst for metamorphic reactions, as a physical medium of transporting chemicals and heat, and are involved in ion-exchange mineral equilibrium reactions (e.g., Jamtveit and Austrheim, 2010). The transition between metamorphism and metasomatism is continuous without a definite boundary; on the microscale, all metamorphic reactions are metasomatic in nature (Putnis and Austrheim, 2010). Metamorphism accompanied by whole rock compositional changes due to chemical exchange among contrasting lithologies and assisted by fluid flow can result in the formation of significant skarn minerals. Analysis of these skarn minerals and the rocks surrounding them can unlock much information about the metasomatic process.

\section{Skarn Formation}

Skarn is found in a variety of geologic settings (e.g., within contact aureoles, faults or shear zones, hydrothermal systems, subduction zones, volcanoes, and deep crustal metamorphic terranes). The term "skarn" does not apply to the metamorphism of a specific protolith under particular conditions, but to a rock with particular mineralogy formed by metasomatic alteration (Drahota and Ackerman, 2004). Skarn is defined as coarse-grained calc-silicate rock with complex mineralogy that forms on the centimeter to hectometer scale, often containing such minerals as garnet, diopside, tremoliteactinolite, epidote, olivine, vesuvianite, wollastonite, and additional $\mathrm{Fe}, \mathrm{Ca}$, and Albearing silicates (e.g., Kerrick, 1977; Ferry et al., 2011). Skarn mineralogy is a function 
of protolith chemistry, the amount and composition of interacting fluids, and the pressures and temperatures of metamorphism.

In intrusive igneous systems, large (meter- to decimeter-) scale metasomatic alteration may occur in adjacent country rock due to the extensive heat and fluid released by the cooling intrusion. The cooling pluton reaches water saturation as anhydrous mineral phases crystallize, releasing excess fluid into the surrounding host rock. Mass transfer occurs as dissolved chemical components are passively transported within the fluid medium that is propelled down-gradient from the higher fluid pressure cooling body to the lower fluid pressure country rock (Kerrick, 1977).

In addition to magmatic fluid released from the cooling magma, metamorphic fluid is also produced by prograde decarbonation and dehydration reactions in metamorphosing carbonates and pelites due to the heat introduced by the magma into the system. Within the country rock, these mobile fluids flow pervasively through intergranular pore space, are selectively channeled through more permeable rock units when encountering rock units with contrasting permeabilities (Davis and Ferry, 1993; Nabelek and Morgan, 2012), and migrate along preexisting structures such as faults, shear zones, fold hinges, and lithological contacts (Thompson and Connolly, 1992; Ferry et al., 2001; Lackey and Valley, 2004). With the assistance of such physical anisotropies to focus flow, metasomatism can propagate over tens and hundreds of meters (Ferry et al., 2001), but its extent is limited by the amount of fluid available, heat of the system, and duration of peak metamorphism (Stern, et al., 1992). 
Mineral zonation is common within skarn rock. During metasomatic exchange between a carbonate-rich host rock and a silicic magma, the interplay of chemical potentials and fluid transport may cause the formation of an endoskarn zone and an exoskarn zone as reciprocal diffusion between contrasting lithologies and subsequent infiltration metasomatism from the pluton to the host rock proceed. Endoskarn is plutonic rock chemically altered by interaction with the adjacent country rock. Endoskarns typically show $\mathrm{K}$ - and Na-depletion along with $\mathrm{Ca}$ - and $\mathrm{Mg}$-enrichment evidenced by diopside, epidote, and other calcic minerals replacing hornblende, biotite, and sodic plagioclase (Kerrick, 1977; Dyer et al., 2011). Conversely, exoskarn is metasomatized country rock enriched in silica, iron, and aluminum and dominated by calc-silicate minerals such as calcic and Fe-rich garnet, pyroxene, epidote, wollastonite, and vesuvianite (Kerrick, 1977; Drahota and Ackerman, 2004).

\section{Stable Isotopes as Evidence of Fluid Migration and Metasomatism}

Stable isotopes are valuable recorders of fluid-rock interaction in hightemperature systems. Nonradiogenic isotopes of elements with low atomic numbers such as $\mathrm{H}, \mathrm{O}, \mathrm{C}$, $\mathrm{N}$, and $\mathrm{S}$ have large relative mass differences between isotopes of the same element, which allow for measurable mass differentiation during natural processes that favor lighter or heavier ions. A heavier isotope of an element has less vibrational energy at the atomic level, and therefore forms stronger, more stable bonds that are less easily broken than the bonds holding a lighter isotope of the same element in the phase. Because of this mass-dependent fractionation, environmental processes cause unique reservoirs to form within the earth, each with a distinct isotopic signature (Faure and Mensing, 2005). 
Metamorphic rocks have unique stable isotopic signatures representative of their protolith, thermal history, and record of fluid interaction (Timon et al., 2007). During contact metamorphism, isotopically distinct fluid expelled from the crystallizing pluton, released by devolatilization reactions within adjacent metamorphic rock, or filtered down from surface sources may infiltrate and propagate through the rock, altering the initial isotope concentrations of the rock by fluid-rock ion exchange and re-equilibration. Prograde devolatilization reactions that release $\mathrm{H}_{2} \mathrm{O}$ and $\mathrm{CO}_{2}$ favor the lighter isotopes of oxygen and carbon, and therefore cause mass fractionation. Because $\mathrm{H}_{2} \mathrm{O}$ and $\mathrm{CO}_{2}$ are the main components of fluid from degassing plutons and metamorphosing rock, oxygen and carbon are two of the most common stable isotopes studied in these metamorphic systems. By measuring ${ }^{18} \mathrm{O} /{ }^{16} \mathrm{O}$ and ${ }^{13} \mathrm{C} /{ }^{12} \mathrm{C}$ variations in whole rock or mineral separate samples from the contact aureole at various locations, mapping these variations, and comparing values with the expected isotopic signatures of the rock type prior to contact metamorphism, much can be learned about fluid mobility through the crust during pluton emplacement (e.g., Ferry et al., 1998; 2001; Timon et al., 2007; Nabelek and Morgan, 2012).

Oxygen Isotopic Signatures of Earth Reservoirs. Oxygen exists in three stable isotopes: ${ }^{18} \mathrm{O},{ }^{17} \mathrm{O}$, and ${ }^{16} \mathrm{O}$. The relative ratio of the heaviest to the lightest of these isotopes is used to describe mass fractionation processes. Liquid and vapor phases concentrate ${ }^{16} \mathrm{O}$ while solid phases with the most stable bonds favor ${ }^{18} \mathrm{O}$. Atmospheric water vapor evaporated from the oceans preferentially loses ${ }^{18} \mathrm{O}$ to precipitation as it progresses inland and northward. With cooling temperatures, fractionation between 
isotopes increases. Thus, meteoric water over the inland northern continents has the lowest ${ }^{18} \mathrm{O} /{ }^{16} \mathrm{O}$. Oceanic sediments and rocks such as diatomaceous earth and carbonates have the highest ${ }^{18} \mathrm{O} /{ }^{16} \mathrm{O}$ due to the high fractionation factor of silicates and carbonates with respect to water at low temperatures within the ocean. Oxygen isotope values for plutonic and metamorphic rock are expressed as $\delta^{18} \mathrm{O}$ vsmow, where, for a given rock sample, $\delta^{18} \mathrm{O}$ is defined as follows:

$$
\delta^{18} \mathrm{O}=\left(\left[{ }^{18} \mathrm{O} /{ }^{16} \mathrm{O}\right] \text { sample } /\left[{ }^{18} \mathrm{O} /{ }^{16} \mathrm{O}\right] \text { standard }-1\right) * 1000 \% .
$$

$\delta^{18} \mathrm{OVSMOW}_{\text {vs }}$ is calculated using the international standard of normalization, V-SMOW (standard mean ocean water from a locality near Vienna, Austria) as $\left({ }^{18} \mathrm{O} /{ }^{16} \mathrm{O}\right)_{\text {standard, }}$ and

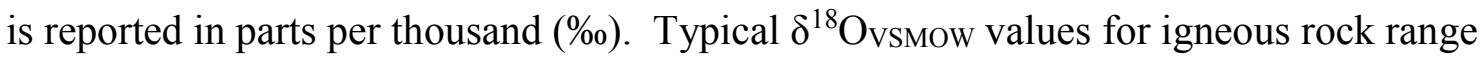
from 2 to $12 \%$ (Fig. 1). The amount of crustal component in the magma determines the variation from V-SMOW. Continental crust-derived melt has higher $\delta^{18} \mathrm{O}$ due to its origin from rock that has undergone processes which concentrate ${ }^{18} \mathrm{O}$. Mantle rocks and basalts with minor crustal contamination have reported $\delta^{18} \mathrm{OVSSM}_{\mathrm{vS}}$ of 5.5 to $5.9 \%$. Rocks that have undergone hydrothermal alteration or interaction with highly negative

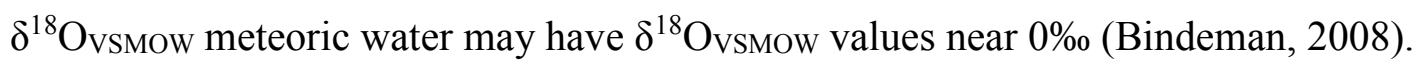




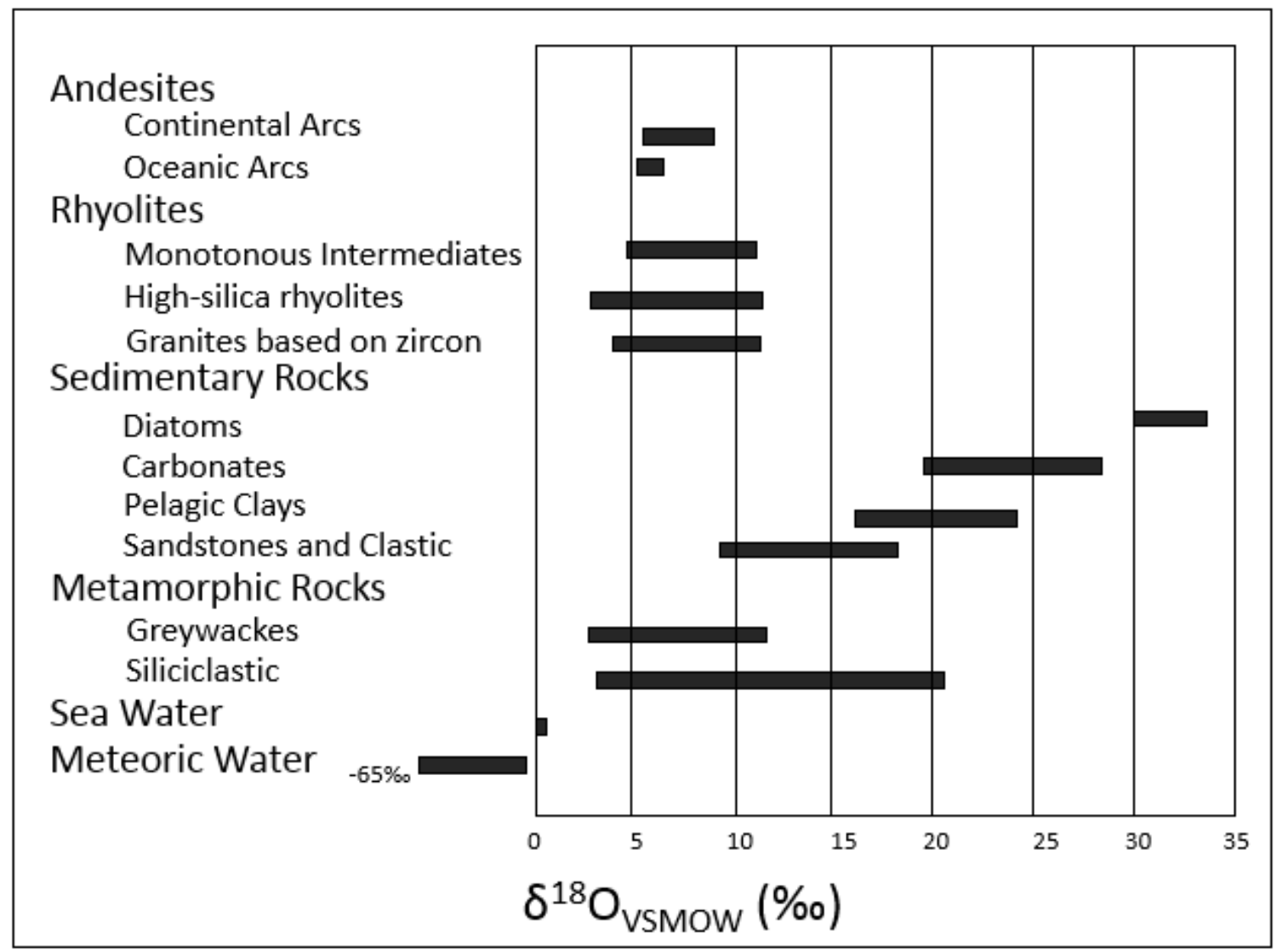

Figure 1. Variations in oxygen isotope ratios for magmas, rocks, and other earth reservoirs, modified from Bindeman (2008). VSMOW = Vienna Standard Mean Ocean Water. $\%$ = Parts per thousand.

Carbon Isotopic Signatures of Earth Reservoirs. Carbon exists in two stable isotopes: ${ }^{12} \mathrm{C}$ and ${ }^{13} \mathrm{C}$. The stable carbon isotope ratio used as a geochemical tracer is ${ }^{13} \mathrm{C} /{ }^{12} \mathrm{C}$, and is typically reported as $\delta^{13} \mathrm{C}_{\mathrm{PDB}}$ for rock samples, where $\delta^{13} \mathrm{C}$ is defined as follows:

$$
\delta^{13} \mathrm{C}=\left(\left[{ }^{13} \mathrm{C} /{ }^{12} \mathrm{C}\right] \text { sample } /\left[{ }^{13} \mathrm{C} /{ }^{12} \mathrm{C}\right] \text { standard }-1\right) * 1000 \%
$$

$\delta^{13} \mathrm{CPDB}_{\mathrm{PD}}$ is calculated using the ${ }^{13} \mathrm{C} /{ }^{12} \mathrm{C}$ of a marine carbonate standard derived from fossil belemnite found in the Peedee Formation of South Carolina, USA, termed PDB, and is reported in parts per thousand $(\%)$. 
The mass dependent fractionation of carbon isotopes between earth reservoirs is controlled by the activity of $\mathrm{CO}_{2}$ and $\mathrm{CH}_{4}$ in biogenic processes such as photosynthesis, and by chemical combustion reactions which release $\mathrm{CO}_{2}$. Sedimentary rock that was formed in equilibrium with ocean water, such as limestone, has $\delta^{13} \mathrm{C}_{\mathrm{PDB}}$ values that depend on the fractionation of carbon between solid carbonate precipitate and the aqueous carbonate species: $\mathrm{CO}_{2}, \mathrm{H}_{2} \mathrm{CO}_{3}, \mathrm{HCO}_{\mathrm{s}}^{-}$, and $\mathrm{CO}_{2}^{-}$. The fractionation factor of carbon among these phases varies with the temperature and $\mathrm{pH}$ of the oceans at the time. This combination of variables results in marine carbonates with age-specific $\delta^{13} \mathrm{CPDB}_{\mathrm{PD}}$ values, as expressed in Figure 2. Interaction of the carbonate with fluid derived from atmospheric or volcanic origin will deplete the initial rock of ${ }^{13} \mathrm{C}$ relative to ${ }^{12} \mathrm{C}$, while metamorphic fluid interaction with the rock will enrich it (Faure and Mensing, 2005). 


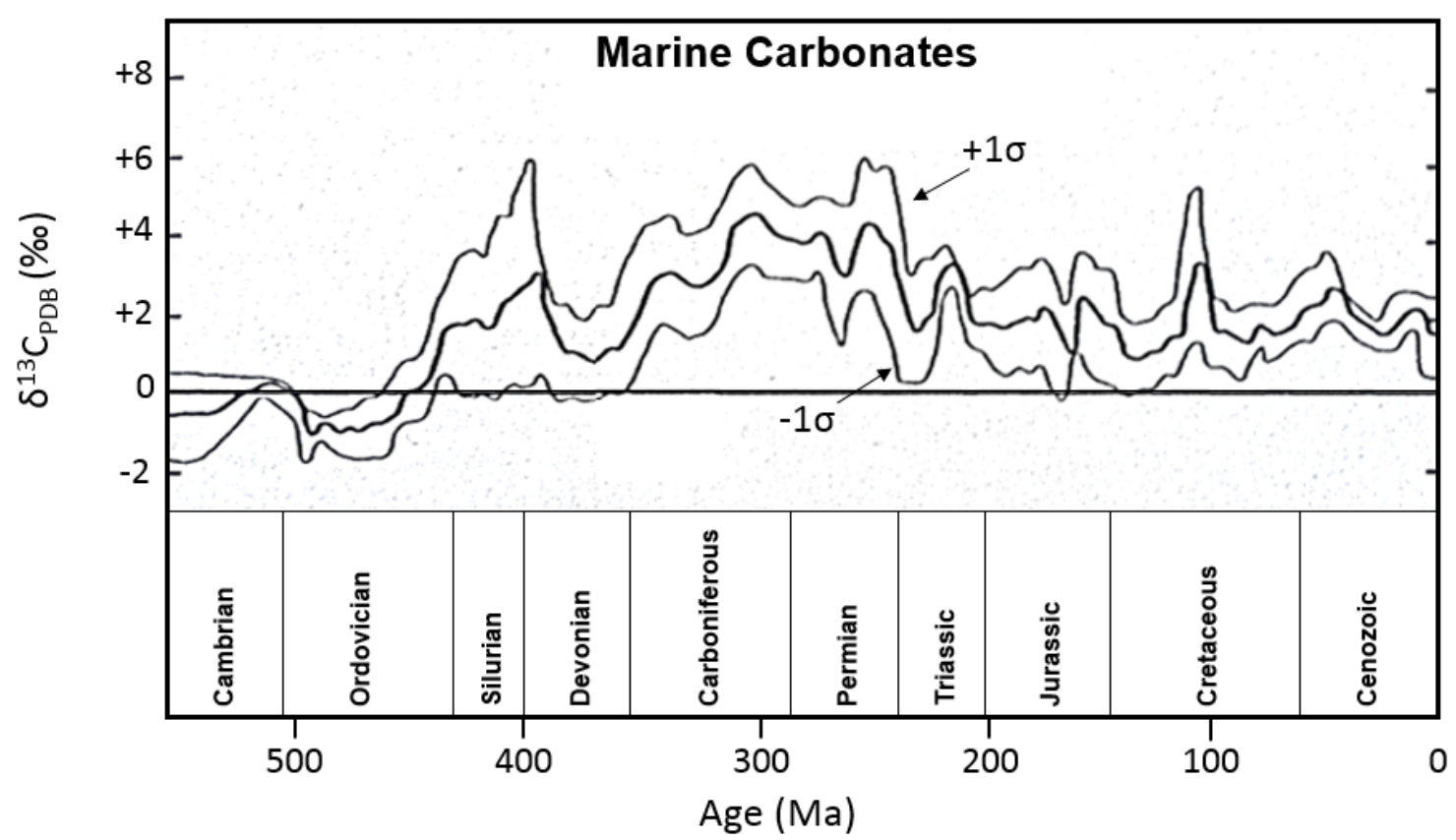

Figure 2. Variations in $\delta^{13} \mathrm{CPDB}_{\mathrm{PD}}$ with respect to time. Upper and lower bounds show \pm 1 standard deviation $(\sigma)$ from the mean. Modified from Faure and Mensing (2005), adapted from Veizer et al. (1999). $\mathrm{PDB}=$ Peedee Formation belemnite standard. $\%=$ Parts per thousand.

\section{Previous Studies of Metasomatism in Contact Aureoles}

Ferry et al. (1998) used mineral data combined with carbon and oxygen isotope measurements to discern the fluid source and flow geometry within vertically oriented beds of siliceous limestone in the Ritter Range roof pendant of the central Sierra Nevada. A clearly-defined wollastonite isograd was determined to have been formed by the mineral reaction:

$$
\text { calcite }+ \text { quartz } \rightarrow \text { wollastonite }+ \text { carbon dioxide. }
$$

In order to interpret the extent of alteration by exotic fluid, the change in isotope ratios due to metamorphic decarbonation of the limestone was removed using the Rayleigh distillation equation (Valley, 1986): 


$$
\delta^{\mathrm{f}}=\delta^{\mathrm{i}}-(1-F) 1000 \ln \alpha
$$

where $\delta^{\mathrm{f}}$ and $\delta^{\mathrm{i}}$ are the final and initial values of $\delta^{18} \mathrm{O}$ or $\delta^{13} \mathrm{C}$ in the rock based on measured concentrations (final) and expected values for the unmetamorphosed siliceous limestone (initial), $F$ is the mole fraction of $\mathrm{CO}_{2}$ remaining in the rock after metamorphism, and $\alpha$ is the fractionation factor between the volatiles being released and the rock for a given temperature. Adjustment of measured isotope values for decarbonation-related depletion or enrichment returned $\delta^{18} \mathrm{OVSMOW}_{\text {values of }} 19-21 \%$ for the metamorphic rock, which is somewhat depleted in ${ }^{18} \mathrm{O}$ relative to unmetamorphosed limestone. Field relations and map analyses suggested that nearby granodiorite and metavolcanic rocks with isotopic signatures of $\delta^{18} \mathrm{O}_{\mathrm{VSMOW}}=9.0 \%$ and $7.4-13.6 \%$, respectively, were possible sources of the fluid. The study concluded that fluid propagated vertically upward parallel to bedding from a deeper source that was chemically and isotopically similar to the granodiorite or metavolcanic rocks, or may have been a combination of the two, but that the two sources could not be distinguished (Ferry et al., 1998).

Ferry et al. (2001) mapped the wollastonite isograd and oxygen isotope profile of the Mt. Morrison roof pendant, which is a structurally complex sequence of metasedimentary rock that underwent faulting, folding, and a $225 \mathrm{Ma}$ felsic dike intrusion prior to contact metamorphism. The pendant was then intruded by granodiorite at approximately $90 \mathrm{Ma}$. The mapped wollastonite isograd and ${ }^{18} \mathrm{O}$ depletion front show extensive structural control of fluid flow along the previously existing faults, fold hinges, and dikes. Based on the spatial correlation between the wollastonite isograd and pluton exposures, 
granodiorite was determined to be the likely source of fluid. Additionally, stable isotope variations in transects across lithologic contacts provided evidence of isotopic exchange and re-equilibration between metamorphic rock layers during layer-parallel flow. The extent of enrichment or depletion of each adjacent metamorphic rock layer depended strongly on porosity, which in turn was controlled by grain size.

Nabelek and Morgan (2012) performed a stable isotope and petrology study of a contact aureole in the White Mountains, CA that was intruded by a suite of plutons between 172-180 Ma. The Neoproterozoic to Cambrian metasedimentary wall rocks are of passive margin origin and consist of quartzites, calc-silicate rocks, schists, and marbles. Original bedding orientations have been rotated to near vertical during pluton emplacement. Stable isotope ratios from calcite and dolomite in the marbles and calcsilicate samples were measured. Comparison of $\delta^{18} \mathrm{OVSSM}_{\text {vs }}$ values between rock types showed depletion of ${ }^{18} \mathrm{O}$ from original isotope values in the calc-silicate rocks $\left(\delta^{18} \mathrm{O}_{\text {vSmow }}=14.5-19.5 \%\right)$ and little to no isotopic shifts in the marbles $\left(\delta^{18} \mathrm{O}_{\text {vSMOW }}=20\right.$ $25 \%$ on average). This lithology-dependent oxygen isotope ratio alteration trend suggests that the impermeability of the marble prevented fluid infiltration into those units. The isotopic shift in calc-silicate rocks was interpreted to be from a combination of two mechanisms: (1) equilibration with magmatic or metamorphic fluid, and (2) isotopic exchange with surrounding silicates that buffered this fluid. Because the observed calc-

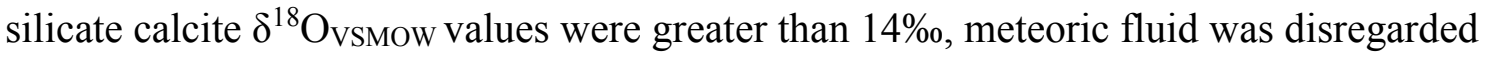
as a possible source of isotope exchange as it has a highly negative $\delta^{18} \mathrm{O}$ vsmow signature 
and would be predicted to shift effected calcite $\delta^{18}$ Ovsmow values well below the values recorded.

\section{Geologic Setting}

The May Lake Interpluton Screen (IPS) is a $4 \mathrm{~km}$-long, $0.5 \mathrm{~km}$-wide discontinuous swath of metamorphic rocks located on the border between the Hetch Hetchy and Tuolumne Meadows geologic quadrangles in the central part of Yosemite National Park (Figs. 3 and 4). The elongate IPS extends northeast to southwest and is bordered to the southeast by a unit of the Tuolumne Intrusive Suite (TIS), 93.1 Ma Glen Aulin tonalite/granodiorite, equivalent to the Kuna Crest granodiorite farther to the east (Coleman et al., 2004). The 102.7 Ma Mount Hoffman quartz monzonite/granodiorite of the Yosemite Valley Intrusive Suite (YVIS) lies to the west and northwest (Taylor, 2004).

The IPS is composed of miogeoclinal metasedimentary rock, the majority of which is quartzite grading into metapelite in localized bands. Calc-silicate rock, metacarbonate rock, and rare metavolcanic rock make up the remaining minor lithologies. Foliated units in the northeast section of the IPS record extensive ductile deformation, with multiple orientations of folding, boudinaging, and overprinting of previous structures suggesting up to five past episodes of deformation before metamorphism by the intruding plutons (Taylor, 2004; Memeti, et al., 2010). The visible evidence of overprinting, including both ductile and brittle periods of deformation, suggest that the more recent contact metamorphism is superimposed on pre-batholithic regional metamorphism (Rose, 1957a). 


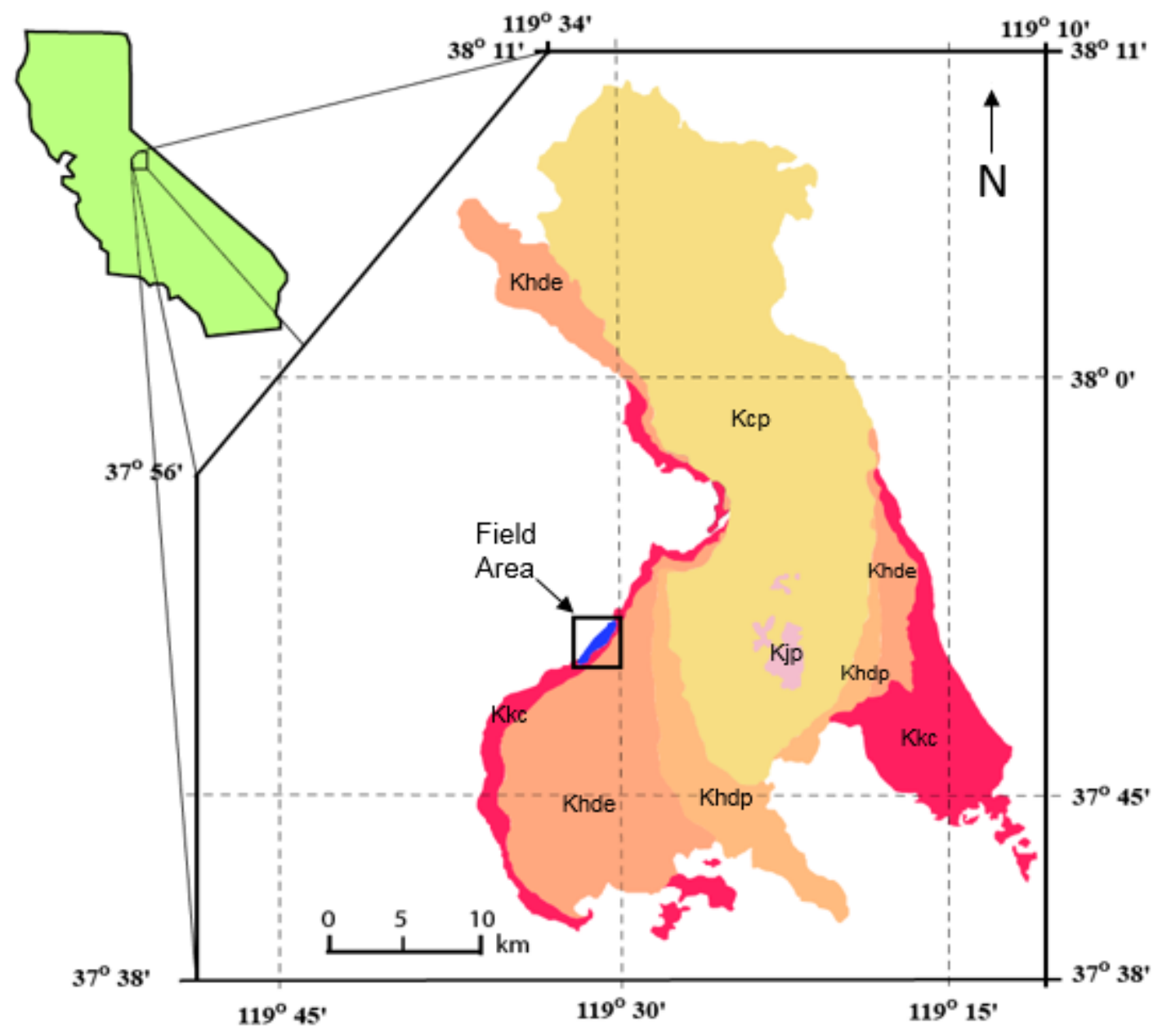

TUOLUMNE INTRUSIVE SUITE

\begin{tabular}{|l|l}
\cline { 1 - 1 } Kjp & Johnson Granite Porphyry \\
\cline { 1 - 1 } Kcp & Cathedral Peak Granodiorite \\
\cline { 1 - 1 } Khdp & porphyritic Half Dome Granodiorite \\
\cline { 1 - 1 } Khde & equigranular Half Dome Granodiorite \\
\hline Kkc & $\begin{array}{l}\text { granodiorite of Glen Aulin (west) } \\
\text { granodiorite of Kuna Crest (east) }\end{array}$ \\
\hline & \begin{tabular}{l} 
May Lake Interpluton Screen (Field Area) \\
\hline
\end{tabular}
\end{tabular}

Figure 3. Location map, modified from Mills (2007). Black rectangle outlines field area shown in Figure 4. 


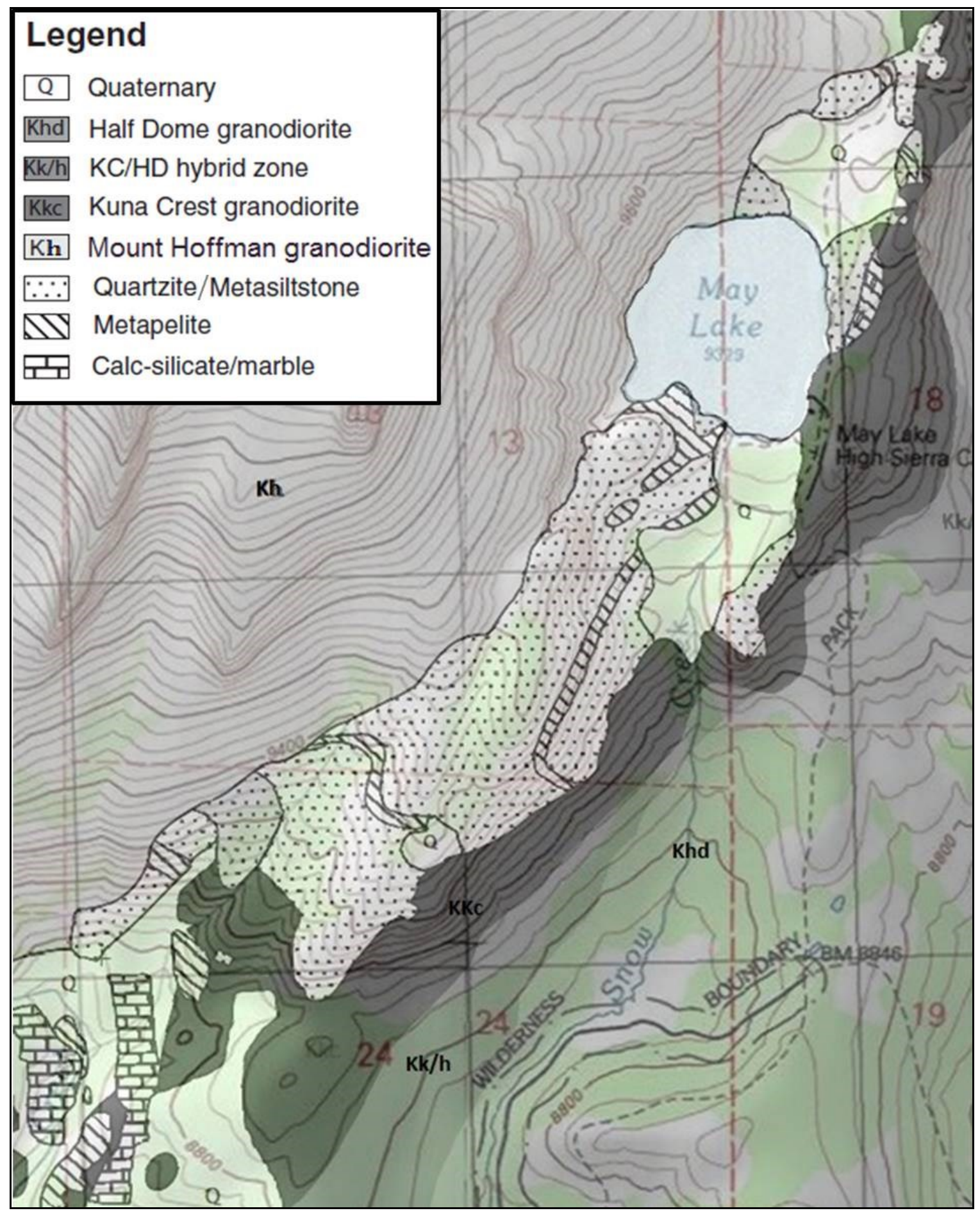

Figure 4. Geologic map of the May Lake IPS, modified after Memeti, et al., 2010. The Kuna Crest granodioritic pluton is referred to as the Glen Aulin tonalite/granodiorite here on its western side. $\mathrm{KC}=$ Kuna Crest, $\mathrm{HD}=$ Half Dome. 


\section{Previous Studies at May Lake}

Rose (1957a and 1957b) studied the metamorphic and granitic rocks of the May Lake area to create 1:5,400 and 1:7,200 scale maps for a Ph.D. dissertation, and published a study focusing on the mineralogy of andalusite-bearing pegmatite dikes intruding the northeast end of the metamorphic screen. Rose (1957a) performed extensive petrographic analysis of each mapped unit and used refractive indices and extinction angles to determine mineral chemistry. Using the most commonly observed metamorphic assemblages hornblende - plagioclase \pm biotite and cordierite - andalusite microcline, Rose categorized the metasedimentary rocks as amphibolite-hornfels facies. From microcline chemical compositions and petrographic microstructures, Rose deduced peak conditions of contact metamorphism as $\sim 540^{\circ} \mathrm{C}$ (Rose, 1957a). Rose calculated an estimated depth of contact metamorphism of the May Lake IPS by using the elevation differences between the IPS and the surrounding granitic rocks along with the ages of the granitic rocks and estimated rates of erosion. Based on this estimated depth, Rose deduced an estimated load pressure of 800-900 bars during contact metamorphism. Based on the calculated age of biotite from one of the pegmatite dikes, Rose concluded that the dikes were genetically related to the TIS (Rose, 1957b).

More recent studies at May Lake have focused on assessing pre-plutonic deformation, pluton emplacement mechanisms, and the effect of the May Lake IPS on pluton geochemistry. Taylor (2004) performed a detailed structural and stratigraphic analysis on the northeastern section of the screen, identified several distinct episodes of deformation that occurred before contact metamorphism, and interpreted pluton emplacement 
mechanisms. Mills (2007) evaluated the extent of geochemical assimilation of the metasedimentary rocks into the Glen Aulin tonalite/granodiorite of the TIS during magmatic emplacement.

An additional area of research involving the May Lake IPS is a regional palinspastic study by numerous sets of authors that generated the Mojave-Snow Lake fault (MSLF) hypothesis. The IPS and several other metamorphic screens and roof pendants lying along the western edge of the TIS to the north and south of May Lake, collectively referred to as the Snow Lake block, are chemically and lithologically distinct from other metasedimentary sequences to the east and west of their current locations or throughout the Sierra Nevada, yet similar to one another (Fig. 5). Stratigraphic evidence suggests that the Snow Lake block may correlate to Paleozoic miogeoclinal units of the Death Valley or Mojave regions of California and Nevada, and that sections of this block were transported via the MSLF, a 102-145 Ma cryptic dextral fault (Fig. 5; Lahren and Schweickert, 1989; Saleeby and Busby, 1993; Memeti et al., 2010). 


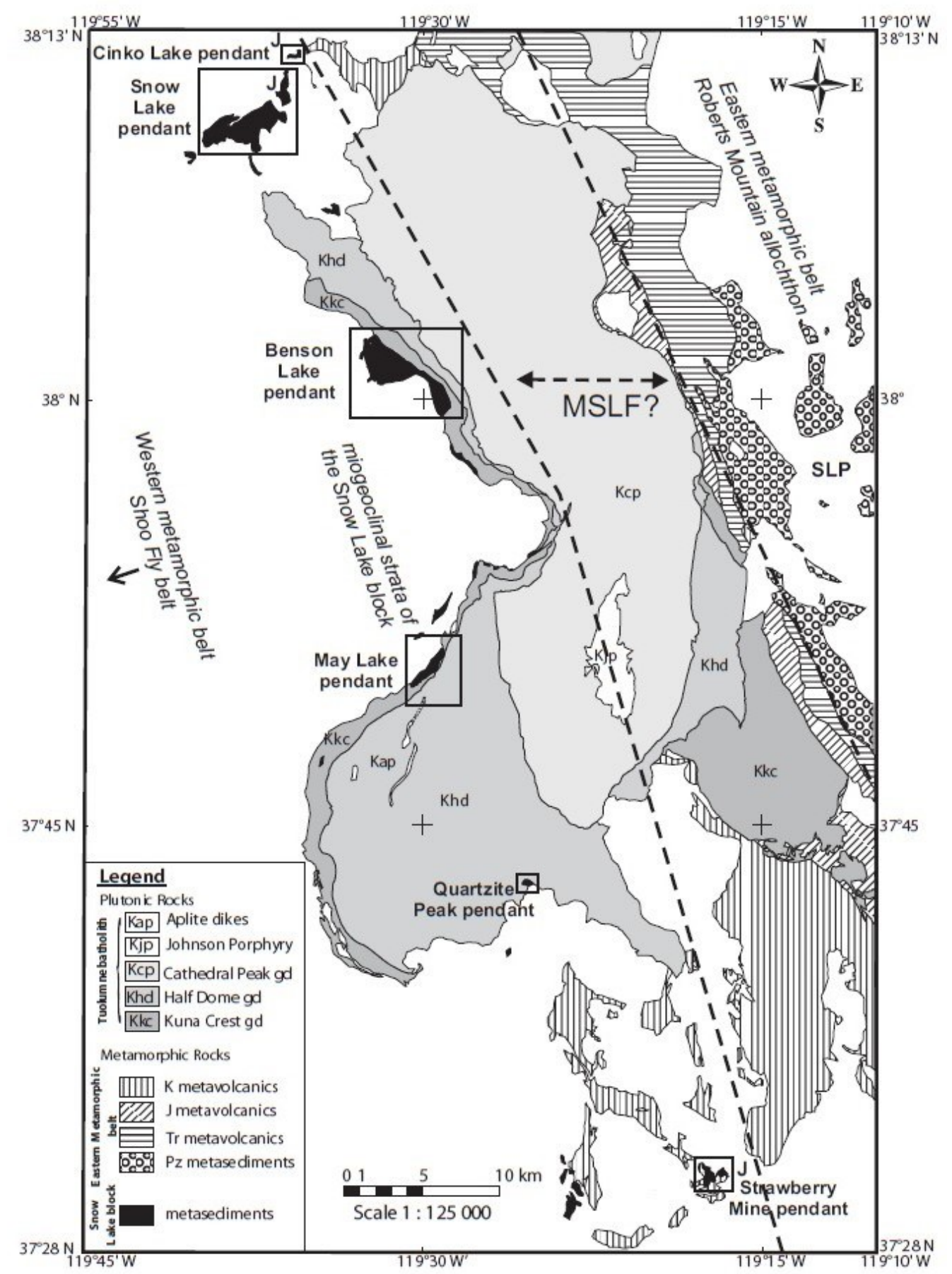

Figure 5. Map showing units of the Snow Lake block and possible location of the Mojave-Snow Lake fault, edited from Memeti et al. (2010). Boxed areas are locations of their study. 
Extensive magmatism, deformational overprinting, and erosion related to the formation of the Sierra Nevada batholith removed surface evidence of the MSLF (Memeti, et al., 2010). Detrital zircon age patterns suggest the metasedimentary rocks of the northeastern section of the May Lake screen correlate with the Ordovician Eureka Quartzite of central Nevada and the Inyo Mountains in California, and therefore the metacarbonates of the southwestern section of the IPS may be similar in origin to the Lower to Middle Ordovician Pogonip Group or the Upper Ordovician Ely Springs Dolomite (Memeti et al., 2010). Additional geochronologic research provides evidence that the faulting required for transportation of these allochthonous rocks from their origin may have been only a few tens of kilometers in extent rather than the originally suggested hundreds of kilometers (Chapman et al., 2015). 


\section{METHODS}

\section{Field Work}

Structural sketches, preliminary hand sample mineralogy notes and rock descriptions, field photographs, GPS-locations, and one hundred and four rock samples were taken from 66 stations throughout the May Lake IPS and adjacent plutons over two field seasons. Station locations for the northeastern and southwestern sections of the IPS are provided in Figures 6 and 7, respectively. Structural data were collected in order to interpret physical relationships that could affect fluid flow among metamorphic units of the screen and between the screen and adjacent plutons. All major identified lithologies were sampled. However, special focus was given to: identifying and sampling different types of skarn; comprehensively representing the mineralogy of the skarn, marble, and calc-silicate rock units; and collecting bulk samples for calcite isotope and whole-rock geochemical analyses. Calcite was positively identified in the field using a solution of dilute hydrochloric acid. 


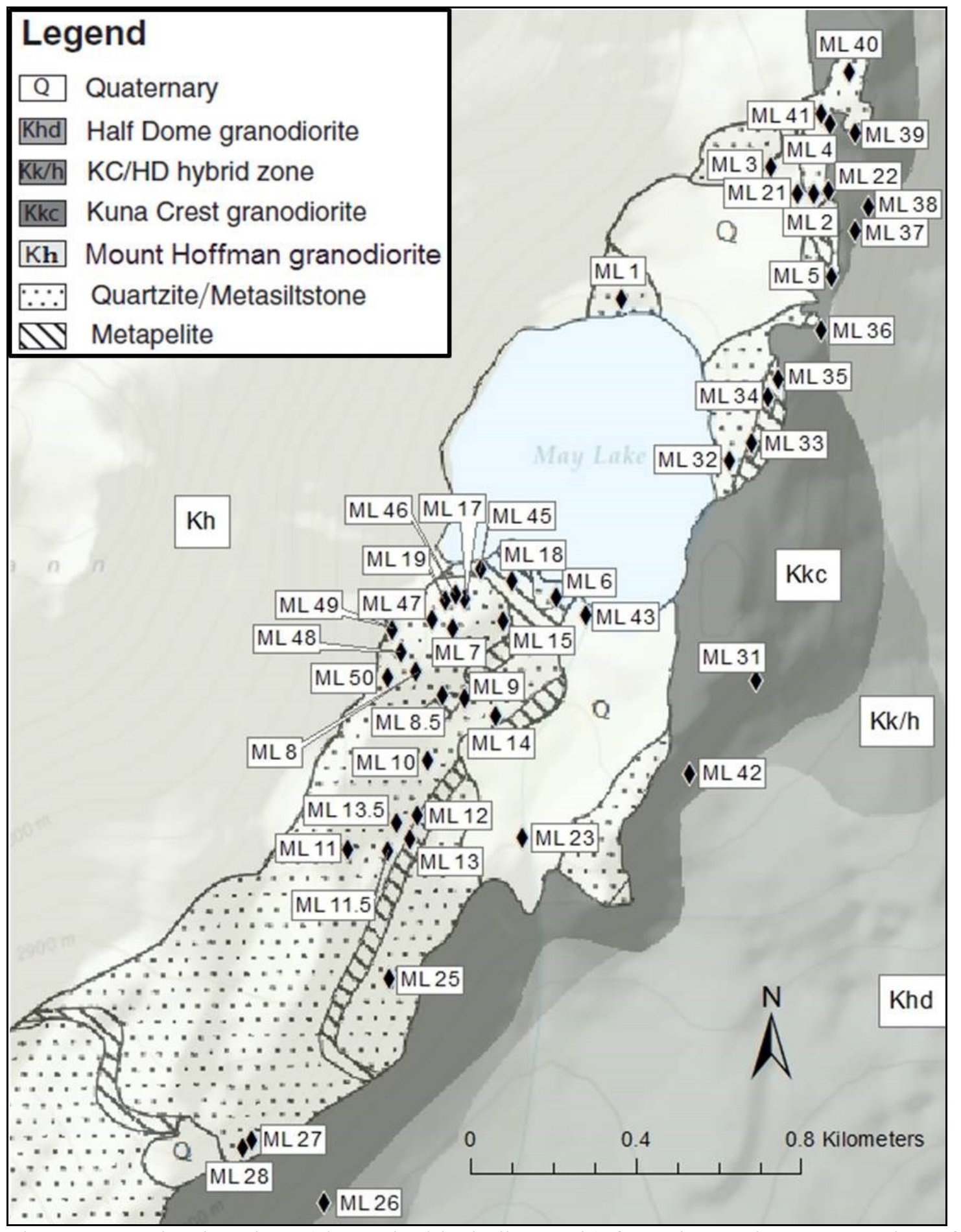

Figure 6. Station locations (shown by black diamonds) from the northeastern section of the May Lake IPS. Geologic map edited from Memeti et al., 2010. KC = Kuna Crest granodiorite, $\mathrm{HD}=$ Half Dome granodiorite. 


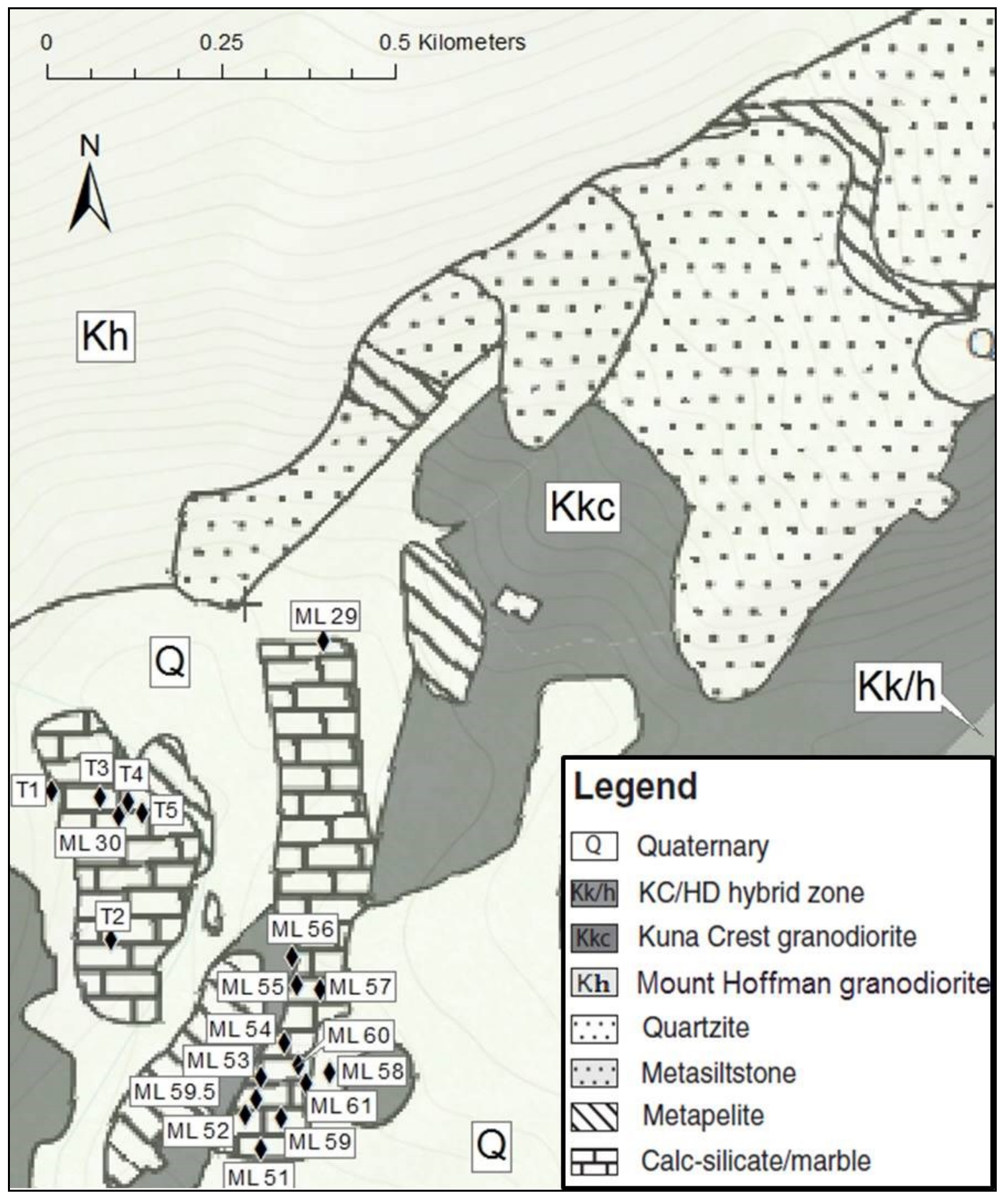

Figure 7. Station locations (shown by black diamonds) from the southwestern section of the May Lake IPS. Geologic map edited from Memeti et al., 2010. KC = Kuna Crest granodiorite, $\mathrm{HD}=$ Half Dome granodiorite. 


\section{Petrography}

Rock descriptions and grain size measurements were recorded for the 104 collected samples. A subset of the samples was selected for more thorough petrologic study to document the mineral assemblages of marbles, calc-silicate hornfels, skarn, and other rocks with minerals, textures, and field relationships of value to interpreting conditions of metamorphism. Mineral assemblages, rock textures, and deformation microstructures were studied in 49 thin sections using a petrographic microscope. Resulting petrographic findings guided the selection for electron microprobe analysis.

\section{Electron Microprobe Analysis}

Seventeen thin sections consisting of calc-silicate hornfels, skarn, metapelite, and granodiorite were polished and carbon coated to $\sim 15 \mathrm{~nm}$ for quantitative wavelengthdispersive electron microprobe analysis of silicate minerals. Qualifying criteria for the thin sections chosen included the presence of distinctive minerals, mineral intergrowths or solid-solution minerals that could indicate relative pressure-temperature conditions with analysis of specific chemistry, and suspected minerals that were difficult to identify confidently through microscopic observation. Of these microprobed samples, all but amphibolite dike sample T2-1 originated from the northeastern section of the screen due to the timing of sample collection, the availability of diverse lithologies from each screen to microprobe, and the more complex field relationships observed in the northeastern section of the screen. Energy-dispersive spectroscopy (EDS) was performed as needed to identify minerals. Thin sections were microprobed in order to determine typical mineral chemistry, variations in mineral chemistry with geographic/geologic location across the 
screen, the chemistry of minerals involved in reaction textures, and mineral growth zoning patterns.

Clinopyroxenes, amphiboles, biotites, and epidotes from 16 thin sections were analyzed using the JEOL 8900 electron microprobe at the USGS Menlo Park geochemical laboratory with a $15 \mathrm{keV}$ accelerating voltage and $10 \mathrm{nA}$ beam current. Five points were microprobed within each grain and results were averaged. Clinopyroxene formulae were calculated based on 6 oxygens per formula unit, epidote based on 12.5 oxygens per formula unit, amphiboles based on 23 oxygens per formula unit, and biotites based on 11 oxygen per formula unit.

Feldspars and garnets were analyzed in 11 thin sections using the UC Davis CAMECA SX-100 electron microprobe. Analyses of feldspars were performed at 15 $\mathrm{keV}$ and $10 \mathrm{nA}$ beam current using a $10.00 \mu \mathrm{m}$ beam, and analyses of garnets were performed at $15 \mathrm{keV}$ accelerating voltage and $20 \mathrm{nA}$ beam current using a $1.00 \mu \mathrm{m}$ beam. Feldspar mineral formulae were calculated based on 8 oxygens per formula unit and garnets were based on 12 oxygens per formula unit. $\mathrm{Fe}^{3+}$ in garnet was calculated to maintain stoichiometric cation charge balance for 8 cations.

Natural and synthetic silicate and oxide standards were used for quality control calibration and internal consistency at both facilities. Analyses with low or high total weight percent oxide sums (less than $98.5 \%$ or greater than $101.5 \%$ for anhydrous minerals and less than $95 \%$ for hydrous minerals) were discarded or recalculated for ferric iron content, when appropriate. 


\section{Whole Rock Geochemistry}

Three fine-grained metapelitic samples were selected for homogeneity, diversity of geographic location within the screen, and lack of weathering, from locations spanning the northeastern section. Weathered surfaces were removed and samples were cut into $\sim 50 \mathrm{~g}$ billets and sent to the Washington State University GeoAnalytical Laboratory for major and trace element analysis by X-ray fluorescence spectrometry (XRF) and Inductively Coupled Plasma Mass Spectrometry (ICP-MS). Major elements were reported in weight percent oxide and trace elements were reported in parts per million. Loss on ignition in percent weight was also reported for each sample.

Pressure-temperature isochemical phase diagrams, termed “pseudosections," were calculated based on the bulk chemistry of each of the three metapelitic samples using Perple_X 6.7.6 (Connolly, 1990; 2009; Connolly and Petrini, 2002) and the Holland and Powell (1998, updated in 2004), internally consistent thermodynamic dataset.

\section{Stable Isotope Mineral Analysis}

Eighteen calcite-bearing samples were selected for oxygen and carbon stable isotope analysis. Of these, one skarn, two fine-grained calc-silicate hornfels, and three marble samples originated from the northeastern section of the screen, while twelve medium- to coarse-grained marble samples were from the southwestern screen. Weathered samples and exposed rock faces were avoided in order to analyze interior sections of rock less altered by recent environmental processes. Calcite-rich portions of the calc-silicate samples and calcite of the skarn and marble samples were carefully selected and ground with ceramic mortar and pestle to a fine powder. Two separate calcite aliquots were 
collected from each of samples ML 26 (skarn from northeastern screen) and T1-1 (marble from southwestern screen) due to visible heterogeneities within the rock samples. Approximately $450 \mu \mathrm{g}$ of the calc-silicate powders and 150-200 $\mu \mathrm{g}$ of the mostly pure calcite powders were analyzed for ${ }^{18} \mathrm{O} /{ }^{16} \mathrm{O}$ and ${ }^{13} \mathrm{C} /{ }^{12} \mathrm{C}$ using a Thermo Finnigan Delta ${ }^{\text {plus }}$ XL Mass Spectrometer at the Stanford University Stable Isotope Biogeochemistry Laboratory. Analytical results were reported in $\delta^{18} \mathrm{OVSMOw}_{\text {VSM }} \delta^{13} \mathrm{C}_{\mathrm{PDB}}$. Measurement precision of \pm 0.02 to $0.10 \%$ was obtained for all but one sample. The calc-silicate sample ML $17-1$ has a precision of $\pm 0.41 \%$ due to a low instrument signal resulting from a low percent weight of carbonate minerals. 


\section{STRUCTURE OF THE MAY LAKE IPS}

The IPS consists of two distinct sections of metamorphic rock separated by Quaternary fill and a band of Tuolumne Intrusive Suite (TIS) at the mapped surface. Due to their lithologic differences and geographic separation, these two sections are referred to in this study as separate screens: the northeastern screen and the southwestern screen. The larger of the two sections, the northeastern screen consists of banded quartzite and metapelite with minor interspersed calc-silicate layers and rare scattered marble pods and lenses from a few centimeters to several meters in size. In contrast, a thick, nearly continuous swath of marble with minor quartzite, metapelite, and metavolcanic rock makes up the much smaller southwestern screen.

Metamorphosed mafic dikes are scattered through both screens and show physical and chemical alteration in the forms of folding, boudinaging, brecciation, and chemical reaction rims in surrounding metasedimentary rock. Granitic pegmatite dikes suspected to originate from the TIS intrude both screens but are more prevalent to the north. Skarn occurs ubiquitously in both screens at contacts between quartzite/metapelite and calcsilicate/marble (metamorphic skarn), at contacts between calcic metasedimentary rock and plutonic rock (magmatic skarn), and as minor veins within calc-silicate rock (vein skarn). 


\section{Contacts}

\section{May Lake IPS Contacts with Surrounding Plutons}

The northeastern screen lies between Mount Hoffman granodiorite of the Yosemite Valley Intrusive Suite (YVIS) to the northwest and Glen Aulin (Kuna Crest) granodiorite of the TIS to the southeast. Contacts between the screen and the plutons are sharp (Fig. 8), strike NE, and dip moderately to the northwest: the YVIS-screen contact is oriented $\sim 220^{\circ}, 32^{\circ} \mathrm{NW}$ near station ML 49; the IPS-TIS contact along the southeastern edge of the screen measures $\sim 220-235^{\circ}, \sim 45^{\circ} \mathrm{NW}$, at multiple locations. The screen overlies the younger TIS at these contacts and underlies the older YVIS.

Xenoliths are preserved within the TIS along the IPS-TIS contact southeast of the IPS. The xenoliths are mostly metapelitic, although a few calc-silicate hornfels xenoliths were also observed (Figs. 9 and 10). The xenoliths range in size from a few $\mathrm{cm}$ in diameter to several meters in length. Mafic enclave swarms are present in the TIS at several locations within a few hundred meters of the southeastern IPS-TIS contact and trend approximately parallel to granitic foliations and the contact.

At the northwestern contact between the YVIS and the IPS, near the western shore of May Lake, Mount Hoffman rises steeply above the screen. Rafts, xenoliths, and stoped blocks were not observed along this contact. The northeastern end of the screen displays extensive interaction between the TIS and YVIS in the form of brecciation and intrusion of aplite dikes from the younger pluton into the older (Fig. 11). Metasedimentary xenoliths tail out from the screen to the northeast within the brecciated zone, along strike with this and other small metamorphic screens in the area. 


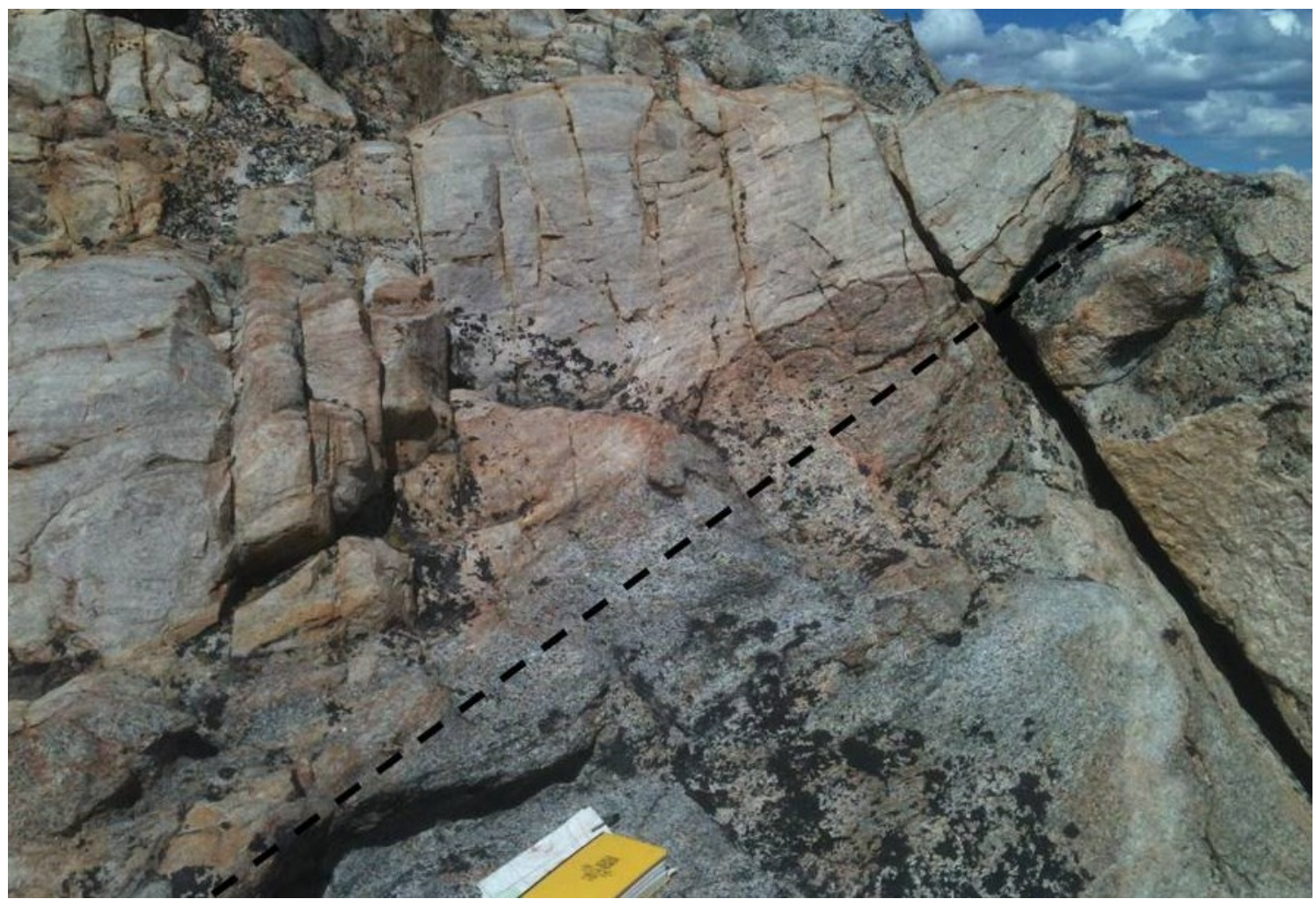

Figure 8. IPS-TIS contact at station ML 36, looking northwest. Quartzite of the May Lake IPS (above, left) and Glen Aulin granodiorite (below, right), with $18 \mathrm{~cm}$ field book for scale. Dotted line shows approximate contact.

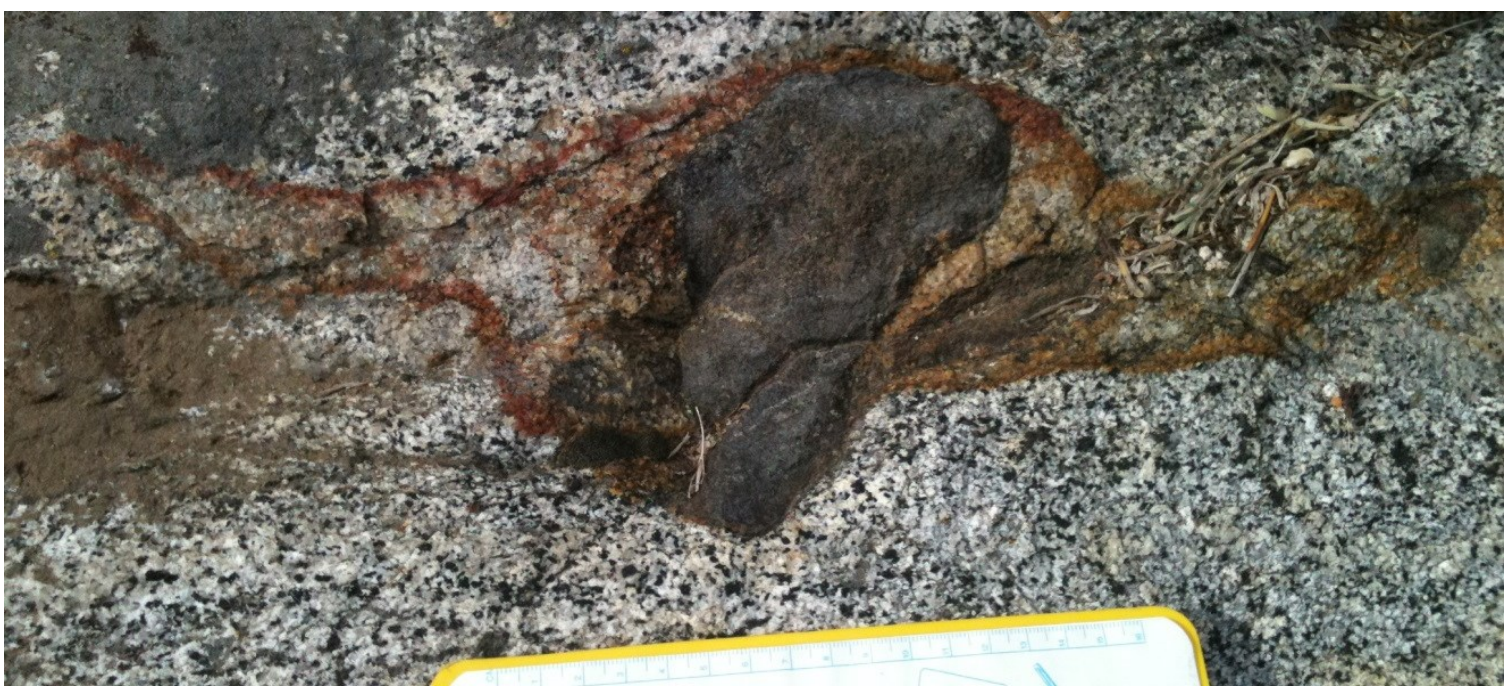

Figure 9. Metapelitic xenolith with reaction rim, within the Glen Aulin granodiorite at station ML 28. $18 \mathrm{~cm}$ field book for scale. 


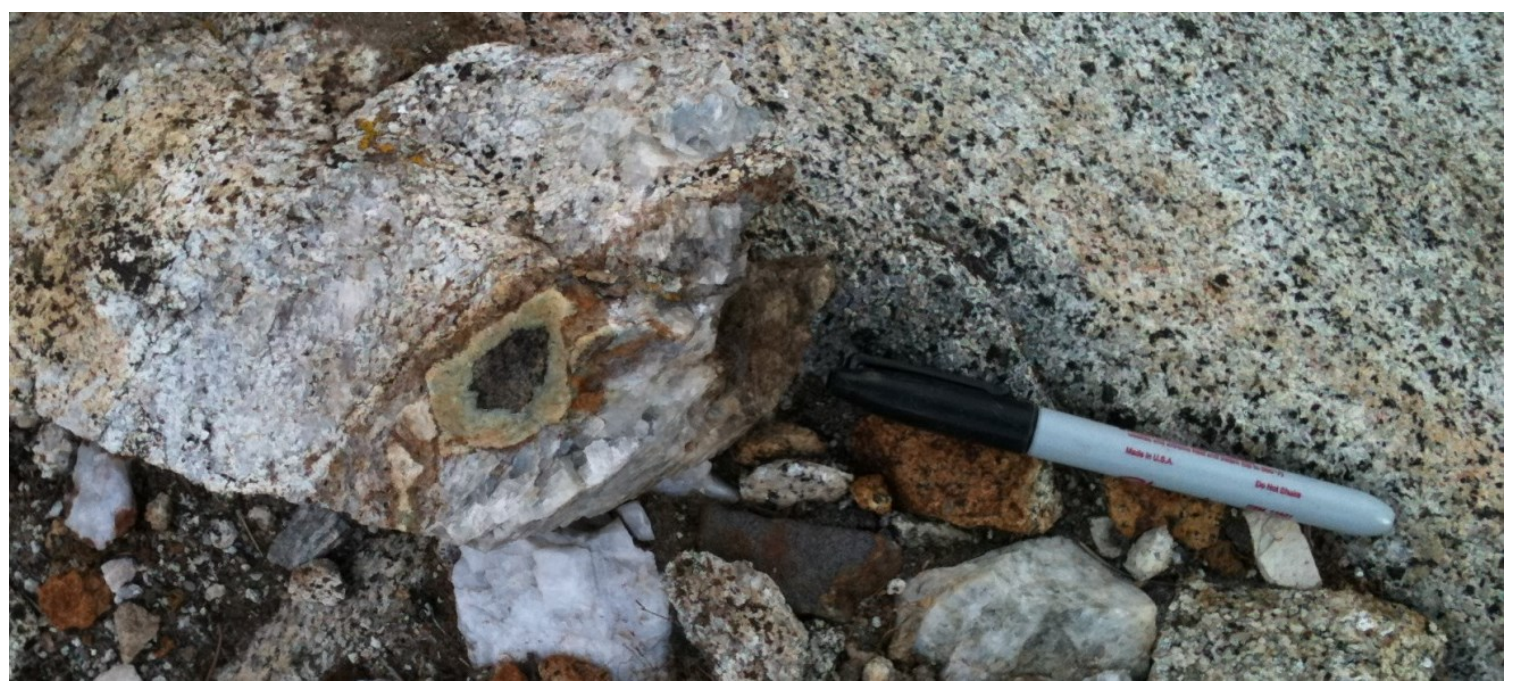

Figure 10. Calc-silicate hornfels xenolith within Glen Aulin endoskarn: sample ML 28-6. $15 \mathrm{~cm}$ long marker for scale.

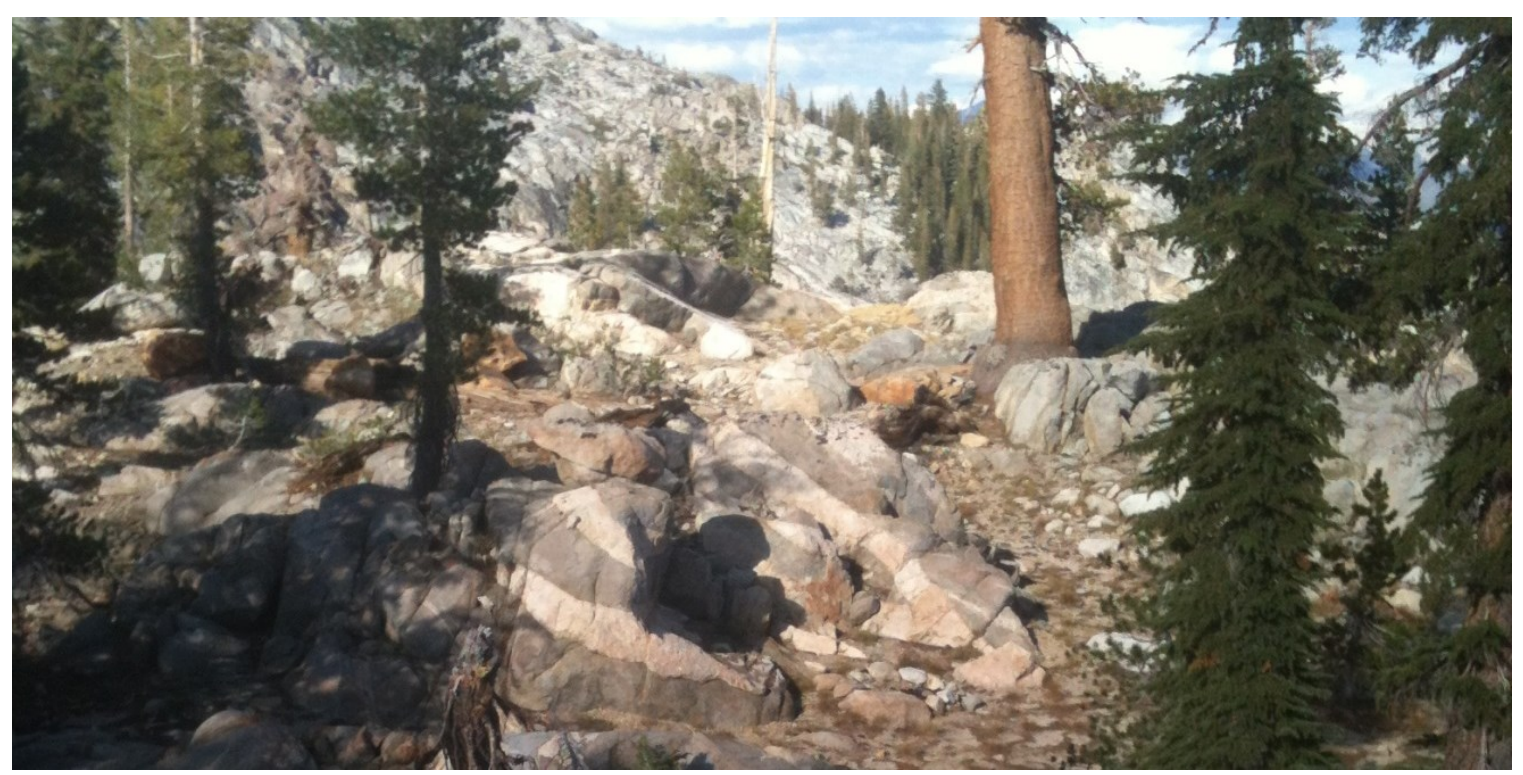

Figure 11. Brecciated granitic rock at the northeastern tip of the May Lake IPS, $\sim 10 \mathrm{~m}$ north of station ML 40, looking northeast approximately along the YVIS-TIS contact. 
The southwestern screen appears to be completely bordered by Glen Aulin granodiorite of the TIS where contacts are visible. Forested Quaternary fill covers much of this lower elevation section of the IPS; contacts between the two screens, and between the southwestern screen and most surrounding granitic rock, are obscured by erosion and sediment infill.

\section{Contacts between Metasedimentary Units}

Contacts between silicic metasedimentary rock and marble or calc-silicate hornfels in the northeastern screen are sharp and marked by fine-grained skarn minerals, typically dark green epidote or dark red to orange garnet. Contacts between mapped units identified as quartzite or metapelite are most commonly gradational transitions from quartzite with minor metapelite bands, to metapelite with minor interspersed quartzite.

\section{Fabrics in Metasedimentary Rocks}

Metasedimentary units of the northeastern screen are heavily folded and boudinaged (Fig. 12). Foliation measured within the northeastern screen shows high variability due to the extensive folding and migmatization, but is generally parallel to pluton-IPS contacts and steeply dipping $\left(10-35^{\circ}, 55-90^{\circ} \mathrm{NW}\right.$, Stereoplot Figs. 13A and B). Much of the marble making up the southern screen has inconsistent foliation (Stereoplot Fig. 14) or foliation that could not be measured; however, strong foliations oriented NW-SE and steeply dipping were observed at stations ML 30 and ML 58 (Fig. 15). 


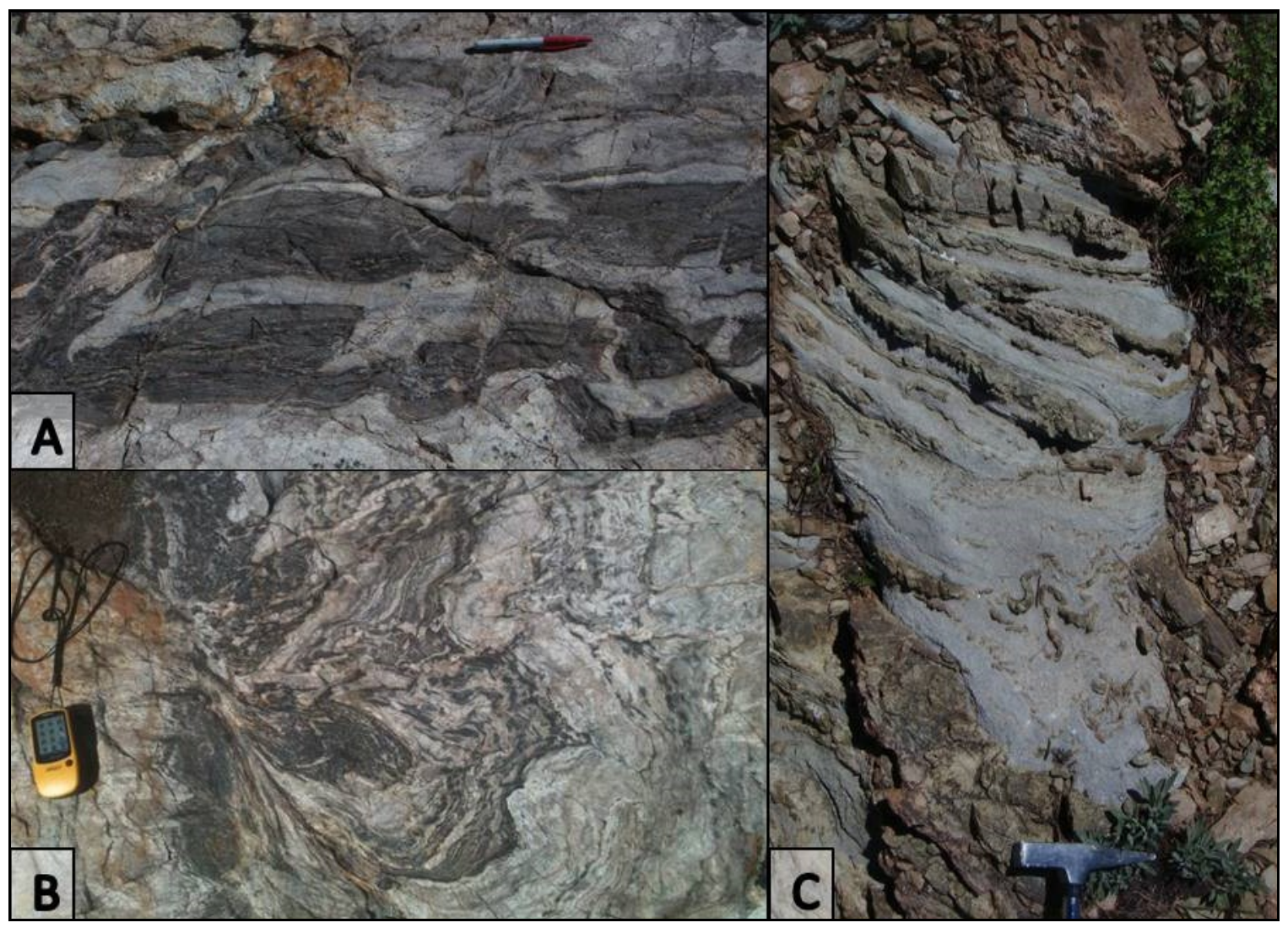

Figure 12. Examples of metapelitic rock structures. A) Folded and boudinaged metapelitic bands within quartzite at station ML 3. Pen for scale. B) Boudinage and ptygmatic folds in metapelite-quartzite near contact with Glen Aulin granodiorite (station ML 33). $\sim 12 \mathrm{~cm}$ length GPS for scale. C) Boudinage and ptygmatic folds in green calcsilicate hornfels interbedded with granular marble at station ML 2. Rock hammer for scale. 


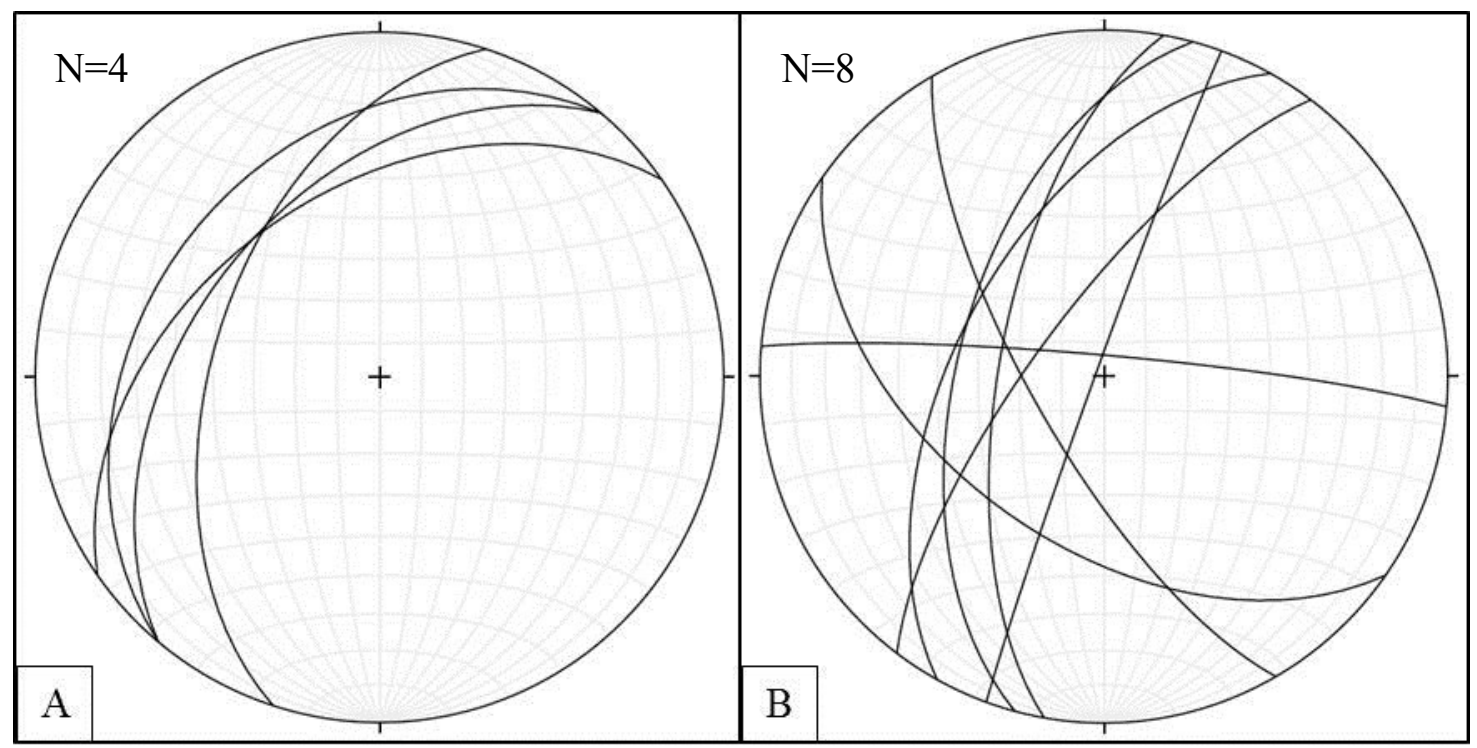

Figure 13. Stereoplots of (A) pluton-IPS contacts, and (B) foliation within the northeastern screen. The stereoplots generated for this study were made using the Stereonet 9.1.0 software of Allmendinger, et al. (2012 ) and Cardoza and Allmendinger (2013).

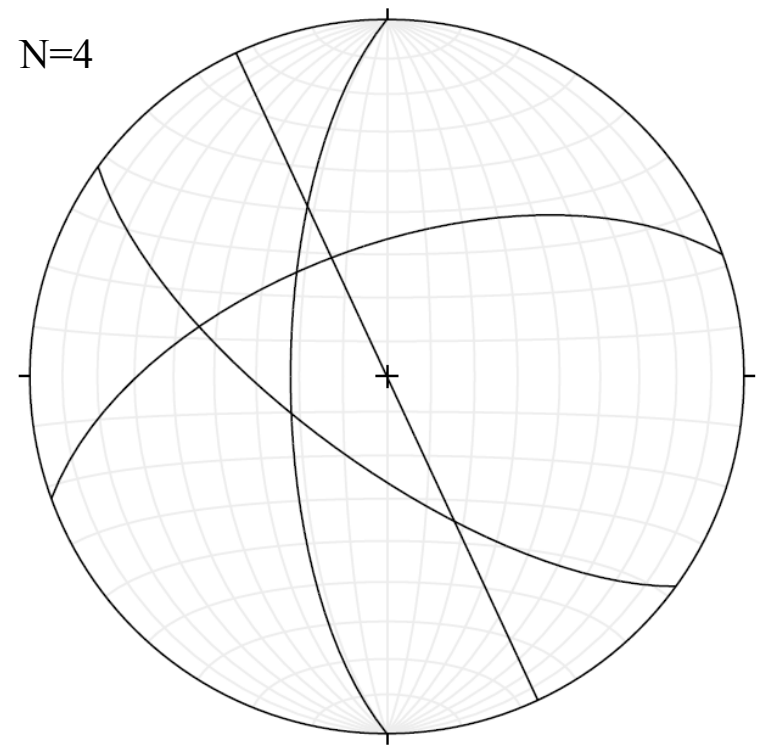

Figure 14. Stereoplot of foliation within the southwestern screen. 


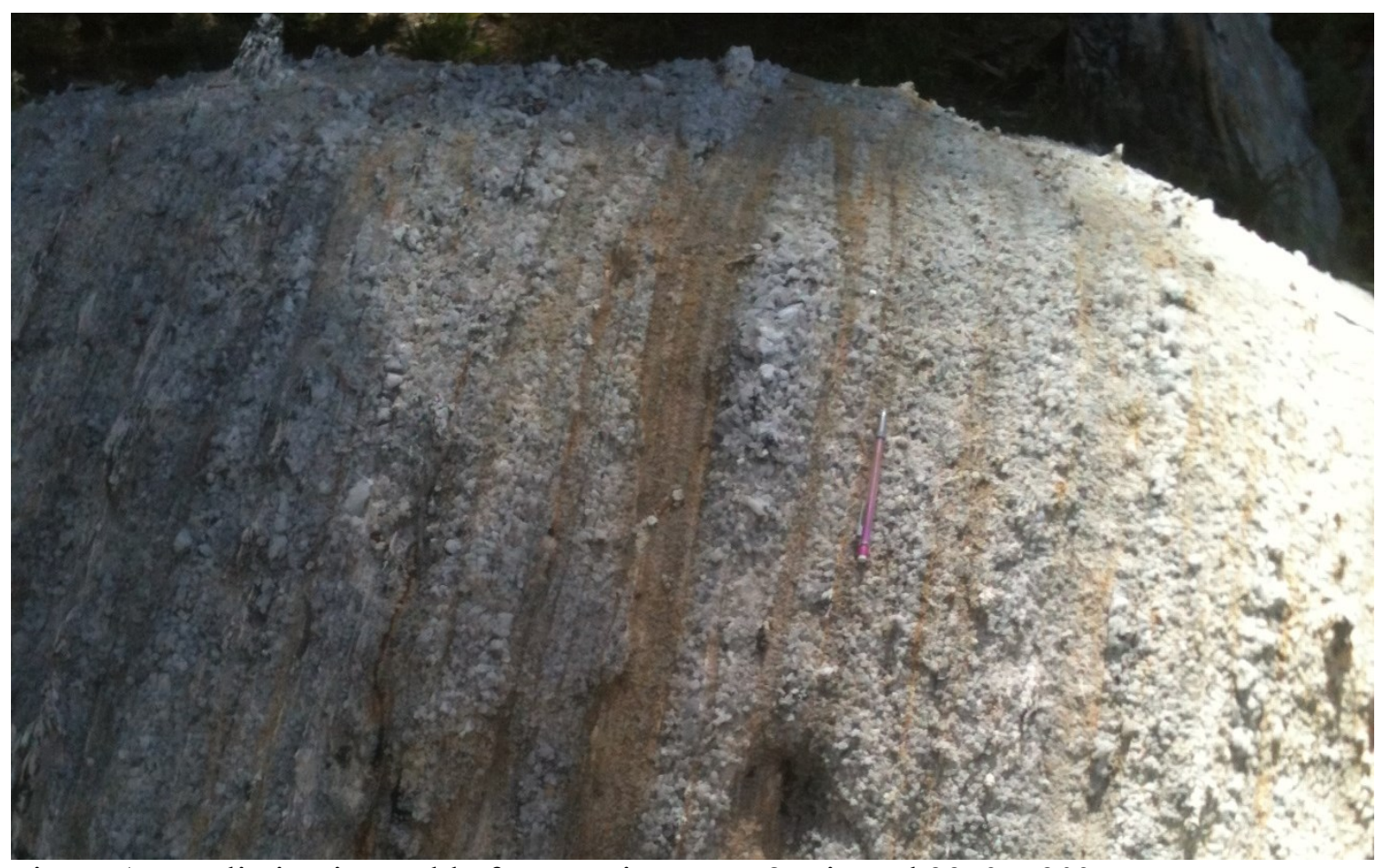

Figure 15. Foliation in marble from station ML 58 oriented $335^{\circ}, \sim 90^{\circ} \mathrm{NE}$.

\section{Dikes}

Metamorphosed mafic dikes of varying thicknesses cut across the metasedimentary rock of the IPS at numerous locations: stations ML 3, ML 4, ML 5, ML 8, ML 11, ML 14, ML 16, and ML 22 of the northeastern screen; stations ML 30, T2, T5, and ML 61 of the southwestern screen (see Methods section Figs. 6 and 7, pages 21 and 22). Most dikes are $\sim 1 \mathrm{~m}$ thick and up to $5 \mathrm{~m}$ in outcrop extent. Observed exceptions to these dimensions include a very thick (>10 m wide) schistose mafic dike at station ML 11 extending up the south face of Mount Hoffman for at least $30 \mathrm{~m}$, in the northeastern screen, and a thin ( 3 to $6 \mathrm{~cm}$ wide) hornfelsic dike cutting through the marble from station ML 60 to ML 61 of the southwestern screen for approximately $40 \mathrm{~m}$ (Fig. 16). 


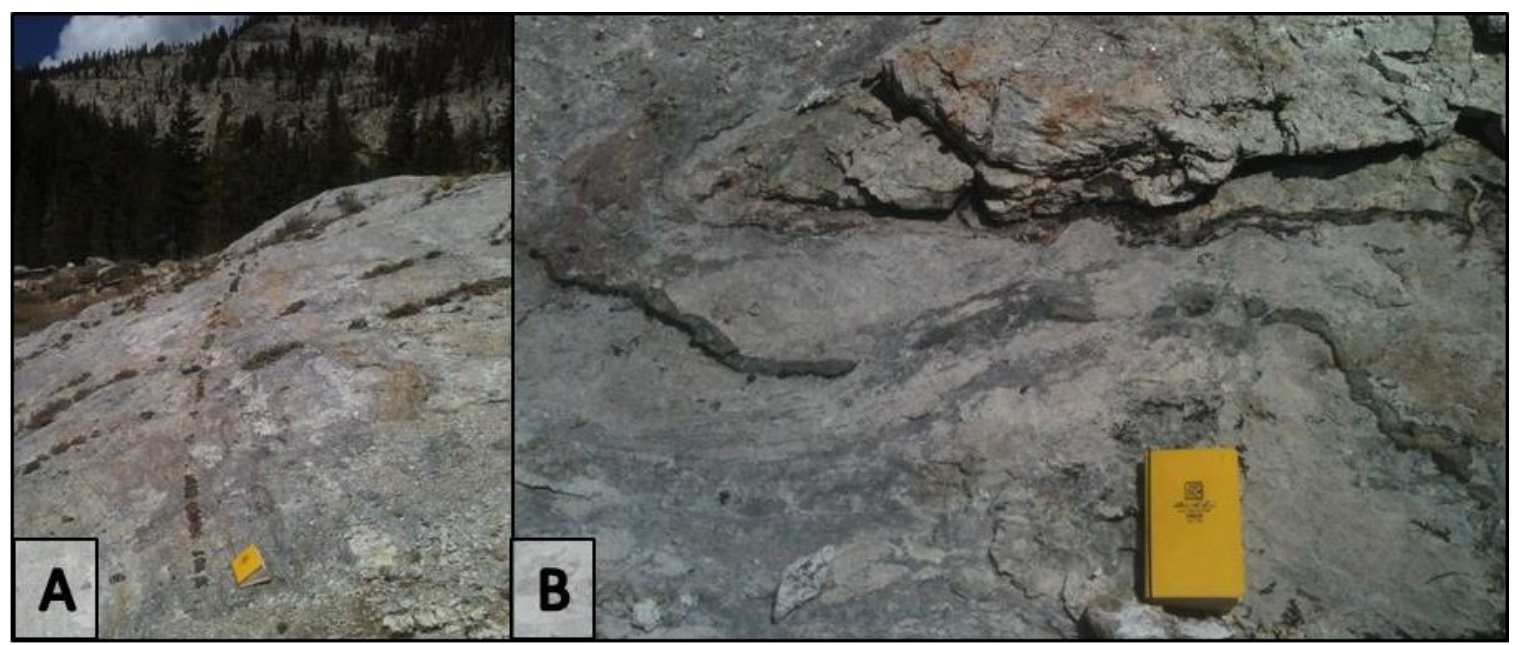

Figure 16. Thin metamorphosed mafic dike in southwestern screen with $18 \mathrm{~cm}$ field book for scale. A) Dike extends between stations ML 60 and ML 61 for $\sim 40 \mathrm{~m}$. B) The southeastern-most extent of the same dike shows thinning out and more ductile deformation than the northwestern-most extent.

Granitic pegmatite dikes intrude the May Lake IPS at stations ML 1, ML 2, ML 21, ML 23, ML 32, ML 36, ML 39, ML 40, ML 41, and ML 43 of the northeastern screen and T3 of the southwestern screen (see Methods section Figs. 6 and 7, pages 21 and 22). Most trend NE-SW and are $\sim 0.5$ to $1 \mathrm{~m}$ thick and 2 to $4 \mathrm{~m}$ in length. Aplite dikes intrude metasedimentary units and metamorphosed mafic dikes in multiple locations throughout the IPS. 


\section{PETROGRAPHY AND MINERAL CHEMISTRY}

General petrographic observations and summaries of mineral chemistry and trends are presented in this section by screen section and by rock type. Mineral chemistry is not presented for all rock types due to the focus on specific minerals and mineral assemblages during the study; primarily minerals of the calc-silicate hornfels and skarn rock types, and minerals that were of interest for P-T information, were selected for mineral chemistry analysis. Sample locations are shown on Figure 6 (p. 21). Mineral abbreviations used in this section are provided in Appendix A. Electron microprobe data are included in Appendix B (Tables B-1 to B-12).

\section{Northeastern Screen}

\section{Quartzite}

Stratigraphic sections of silicic and aluminous metasedimentary rock consisting primarily of quartzite and metapelite make up $>90 \%$ of the northeastern screen. The quartzite is typically vitreous, fine-grained, and varying in color from homogeneous white to light gray due to the increased presence of thin wisps, streaks, and bands of

mafic minerals, primarily biotite and magnetite. Thin sections of quartzite are typically 95-98\% quartz with biotite, opaque minerals (mostly magnetite), minor K-feldspar and muscovite, and rare rutile (Table 1). 
Table 1. Representative quartzite mineralogy and sample descriptions.

\begin{tabular}{|c|c|c|c|c|c|c|c|c|}
\hline \multirow{2}{*}{$\begin{array}{l}\text { Sample } \\
\text { Name }\end{array}$} & \multirow{2}{*}{ Description } & \multicolumn{7}{|c|}{ Minerals identified in thin section* } \\
\hline & & Qtz & $\mathrm{Bt}$ & Crd & Kfs & Wmca & Rt & opq \\
\hline ML 1-3A & Medium grained grey white quartzite. & $\mathrm{x}$ & $\mathrm{x}$ & & & $\mathrm{x}$ & & $\mathrm{x}$ \\
\hline ML 3-2 & $\begin{array}{l}\text { Fine-grained quartzite at contact with } \\
\text { fine-grained metapelite. }\end{array}$ & $\mathrm{x}$ & $\mathrm{X}$ & $\mathrm{x}$ & & $\mathrm{x}$ & $\operatorname{tr}$ & $\mathrm{X}$ \\
\hline ML 3-3 & Medium-grained white quartzite. & $\mathrm{x}$ & $\mathrm{x}$ & $\mathrm{x}$ & $\mathrm{x}$ & $\mathrm{x}$ & $\operatorname{tr}$ & $\mathrm{x}$ \\
\hline ML 5-1 & $\begin{array}{l}\text { Fine-grained homogenous white } \\
\text { quartzite. }\end{array}$ & $\mathrm{x}$ & $\mathrm{X}$ & & & $\mathrm{x}$ & $\operatorname{tr}$ & $\mathrm{X}$ \\
\hline ML 14-2 & $\begin{array}{l}\text { Greyish-white medium-grained } \\
\text { quartzite. }\end{array}$ & $\mathrm{x}$ & $\mathrm{X}$ & & & $\operatorname{tr}$ & $\operatorname{tr}$ & $\mathrm{X}$ \\
\hline
\end{tabular}

Rutile is present as inclusions within the quartz. Sub-grain rotation, grain boundary migration, and undulatory extinction of quartz grains are present in quartzite from stations ML 3, ML 5, and ML 14. Quartz grains in quartzite from station ML 1 show sharp $120^{\circ}$ grain boundaries as well as occasional sub-grain rotation or undulatory extinction (Fig. 17). Biotite-magnetite intergrowths were observed in thin sections of quartzite from station ML 1. 


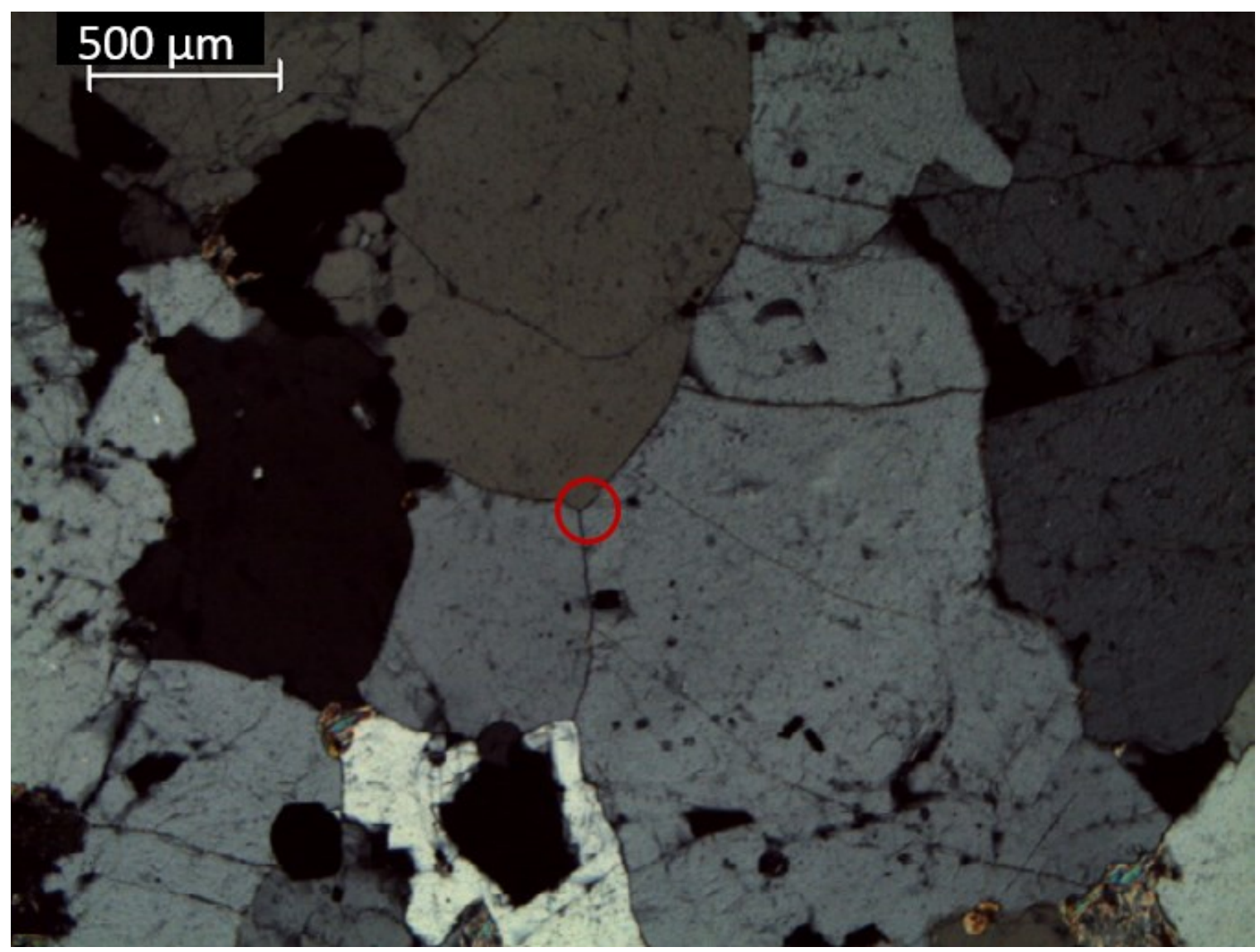

Figure 17. Photomicrograph of quartzite sample ML 1-3A in cross polarized light. Example of $120^{\circ}$ grain boundaries is marked by red circle.

\section{Metapelite}

The quartzite is interlayered with fine-grained metapelite bands of varying thicknesses. Metapelite is dark gray, brownish gray, or grayish blue, and transitions from primarily hornfelsic to occasionally schistose with increasing grain size. Thin sections made from metapelitic rock show the mineral assemblages quartz-biotite-cordieritemuscovite-magnetite, quartz-biotite-K-feldspar-cordierite-magnetite, and quartz-biotiteK-feldspar-muscovite-magnetite (Table 2). Magnetite was confirmed as the predominant opaque mineral in these rocks using electron microprobe analysis. Additional minerals 
Table 2. Representative metapelite mineralogy.

\begin{tabular}{|c|c|c|c|c|c|c|c|c|c|c|c|c|c|}
\hline \multirow{2}{*}{ Sample Name } & \multicolumn{13}{|c|}{ Minerals identified in thin section* } \\
\hline & Qtz & $\mathrm{Bt}$ & Crd & Kfs & $\mathrm{Pl}$ & Wmca & Sil & Ttn & $\mathrm{Rt}$ & Zrn & opq & And & Chl \\
\hline ML 1-5 & $\mathrm{x}$ & $\mathrm{x}$ & $\mathrm{x}$ & & & $\operatorname{tr}$ & $\mathrm{x}$ & & $\operatorname{tr}$ & $\operatorname{tr}$ & $\mathrm{x}$ & $\mathrm{x}$ & $\operatorname{tr}$ \\
\hline ML 3-2 & $\mathrm{x}$ & $\mathrm{x}$ & $\mathrm{x}$ & $\mathrm{x}$ & & $\mathrm{x}$ & $\mathrm{x}$ & & & & $\mathrm{x}$ & & $\mathrm{x}$ \\
\hline ML 4-5 & $\mathrm{x}$ & $\mathrm{x}$ & $\mathrm{x}$ & & & $\mathrm{x}$ & & & & & $\mathrm{x}$ & & \\
\hline ML 6-2 & $\mathrm{x}$ & $\mathrm{x}$ & $\mathrm{x}$ & & $\mathrm{x}$ & & & & & $\operatorname{tr}$ & $\operatorname{tr}$ & & \\
\hline ML 13.5-1 & $\mathrm{x}$ & $\mathrm{x}$ & $\mathrm{x}$ & $\mathrm{x}$ & $\mathrm{x}$ & & & $\operatorname{tr}$ & $\operatorname{tr}$ & $\operatorname{tr}$ & $\mathrm{x}$ & & \\
\hline
\end{tabular}

Minerals making up $<1 \%$ of the thin section are described as trace (tr).

*Mineral abbreviations are provided in Appendix A.

identified in thin section include sillimanite, plagioclase feldspar, rutile, andalusite, zircon, and titanite. Quartz in metapelitic samples varies from 10\% to 35\%. Prismatic sillimanite is present in samples from stations ML 1 and ML 3. Andalusite is also present in sample ML 1-5. In general, the sillimanite is euhedral while the andalusite is subhedral and partially altered to sericite, suggesting that the andalusite was present prior to formation of the sillimanite. Titanite is found in metapelite from stations ML 11.5 and ML 13.5. These two stations are located in the central section of the northeastern screen, within $\sim 100 \mathrm{~m}$ of the massive ( $>30 \mathrm{~m}$ long by $\sim 10 \mathrm{~m}$ thick) metamorphosed mafic dike outcropping on the south face of Mount Hoffman at station ML 11. Biotite in sample ML $6-2$, collected from the southwestern shore of May Lake is annite-phlogopite with $\sim 63 \%$ annite with 3.30 to 4.04 (wt. \%) $\mathrm{TiO}_{2}$ (Table B-2). 


\section{Calc-Silicate Hornfels}

Calc-silicate hornfels is widely dispersed throughout the northeastern screen, but makes up only a small percentage of the screen. It occurs intermittently as banded layers and thin lenses with marble within the quartzite-metapelite units (Figs. 18A and B).

Calc-silicate is typically fine-grained and banded with distinct pink garnet-rich and green clinopyroxene-rich sections. Boudinaging and ptygmatic folding are common for the calc-silicate hornfels when adjacent to or interlayered with marble (Fig. 18A).

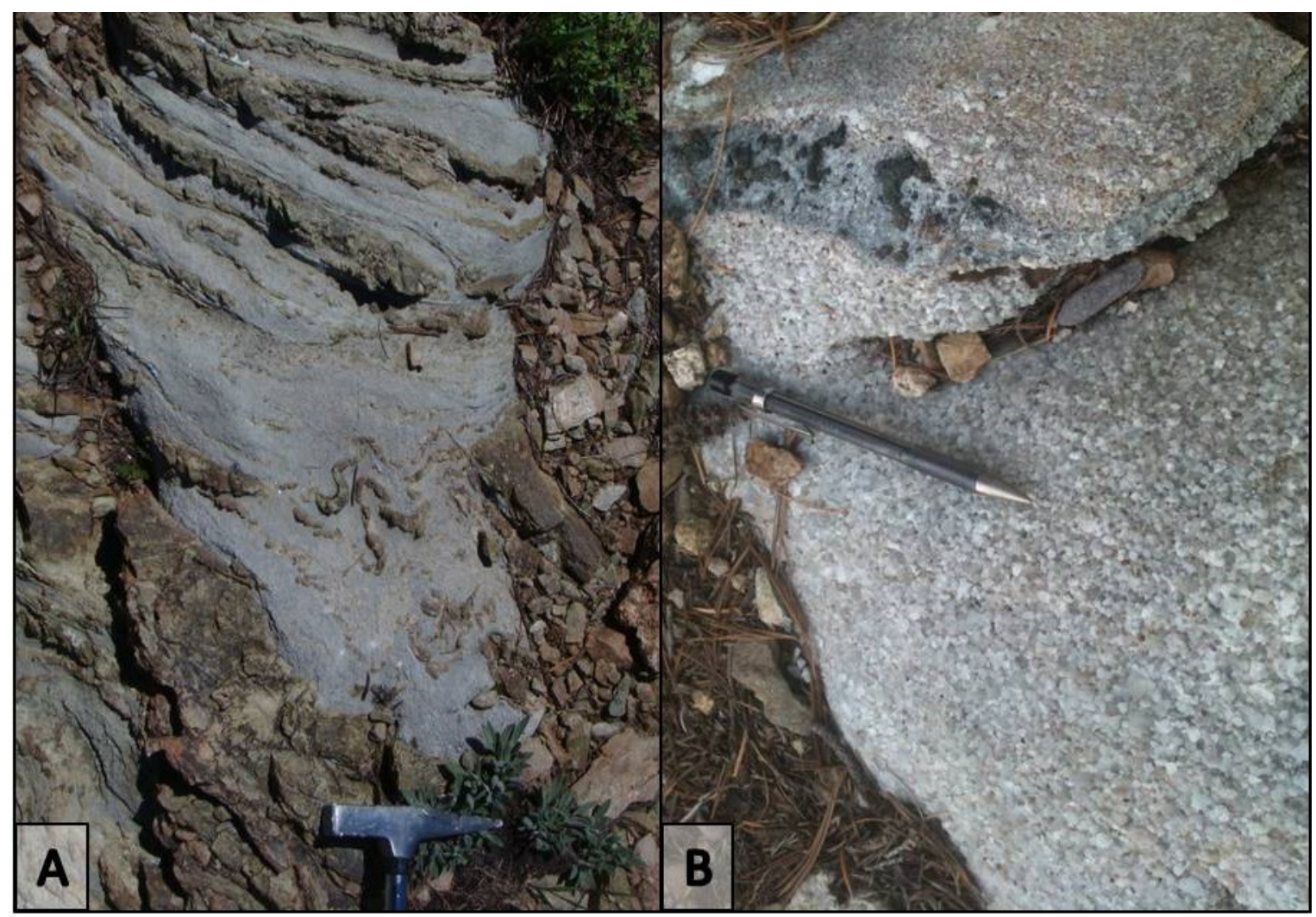

Figure 18. Calc-silicate and marble in northeastern screen. A) Medium-grained gray marble interlayered with fine-grained, boudinaged and ptygmatically folded calc-silicate at station ML 2. Rock hammer for scale. B) Pod of coarse-grained, light-gray marble at station ML 46. Pencil for scale aligned parallel to foliation. 
Green to dark green bands of fine-grained clinopyroxene + plagioclase + quartz \pm calcite alternate with pink or pinkish-beige bands of fine-grained garnet + plagioclase \pm quartz \pm calcite to make up most calc-silicate rock thin sections. Bands of calcite + plagioclase and calcite + clinopyroxene + garnet \pm plagioclase are also present.

Additional minerals include actinolite, titanite, and epidote (Table 3). Calc-silicate rocks sampled from stations ML 6 and ML 7 consist of plagioclase, clinopyroxene, quartz, and green, bladed or fibrous actinolite.

Table 3. Select calc-silicate hornfels mineral assemblages.

\begin{tabular}{|c|c|c|c|c|c|c|c|c|}
\hline Sample Name & Qtz & Cpx & Grt & Ep & Act & $\mathrm{Pl}$ & Cal & opq \\
\hline ML 2-1 & & $\mathrm{x}$ & $x^{*}$ & $\mathrm{x}^{*}$ & & $\mathrm{x}$ & $\mathrm{x}$ & \\
\hline ML 6-4 & & $\mathrm{x}$ & & $\mathrm{X}^{*}$ & $\mathrm{x}$ & $\mathrm{x}$ & & \\
\hline ML 6-5 & & $\mathrm{x}$ & & & $\mathrm{x}$ & $\mathrm{x}$ & & \\
\hline ML 7-1 & $\mathrm{x}$ & & & & $\mathrm{x}$ & & & \\
\hline ML 17-3 & $\mathrm{x}$ & $\mathrm{x}$ & $\mathrm{x}$ & & & $\mathrm{x}$ & $\mathrm{x}$ & \\
\hline ML 19-2 & $\mathrm{x}$ & $\mathrm{x}$ & $\mathrm{x}$ & & & $\mathrm{x}$ & & \\
\hline ML 21-2 & & $\mathrm{x}$ & $\mathrm{x}$ & & & $\mathrm{x}$ & $\mathrm{x}$ & $\mathrm{x}$ \\
\hline ML 23-1 & $\mathrm{x}$ & $\mathrm{x}$ & $\mathrm{x}$ & & & & & \\
\hline ML 23-4 & $\mathrm{x}$ & $\mathrm{x}$ & & & & $\mathrm{x}$ & & \\
\hline ML 25-1 & & $\mathrm{x}$ & $\mathrm{x}$ & & & $\mathrm{x}$ & & \\
\hline
\end{tabular}

Grain boundary migration and subgrain rotation are visible in quartz grains in the thin section of coarser-grained calc-silicate hornfels sample ML 7-1, but otherwise such microstructures were largely absent in the calc-silicate samples, likely due to the fine- 
grained character of the calc-silicate hornfels rocks. Skarn veins consisting of calcite, garnet, and epidote ubiquitously fill fractures in these rocks.

Clinopyroxene, garnet, and plagioclase were analyzed by electron microprobe in five fine-grained calc-silicate hornfels samples from the northeastern screen (samples ML 192, ML 23-1, ML 25-1, ML 21-2, and ML 23-4; mineral chemistry presented in Tables B3, B-4, and B-5). ML 19-2, ML 23-1 and ML 25-1 are typical fine-grained pink and green banded calc-silicate hornfels consisting of clinopyroxene and garnet with quartz and/or plagioclase; ML 21-2 and ML 23-4 are fine-grained clinopyroxene-rich calcsilicate hornfels adjacent to granitic pegmatite dikes. Garnet + epidote-bearing skarn is visible at the pegmatite-hornfels contact near ML 21-2.

Clinopyroxene Mineral Chemistry. Clinopyroxene in calc-silicate samples is diopside-hedenbergite ranging in composition from 58 to $86 \%$ diopside (Table B-3). $\mathrm{Mg}^{2+}$ content varies with location: calc-silicate hornfels samples from more northeastern stations ML 19 (southwestern end of May Lake) and ML 21 (northeast of May Lake) have more Mg-rich and Fe-poor clinopyroxene than samples from central stations ML 23 and ML 25 (Fig. 19). Clinopyroxene from sample ML 21-2 is more $\mathrm{TiO}_{2}$-rich than in other samples and has approximately $1 / 3$ apfu Tschermak substitution: $\mathrm{Fe}^{2+(\mathrm{VI})}+$ $\mathrm{Si}^{(\mathrm{IV})} \leftrightarrow \mathrm{Al}^{(\mathrm{VI})}+\mathrm{Al}^{(\mathrm{IV})}$ (Fig. 20 and Table B-3). Sample ML 21-2 was collected from a calc-silicate hornfels lens with interbedded marble, adjacent to a granitic pegmatite dike with epidote-bearing skarn at the hornfels-pegmatite contact. 


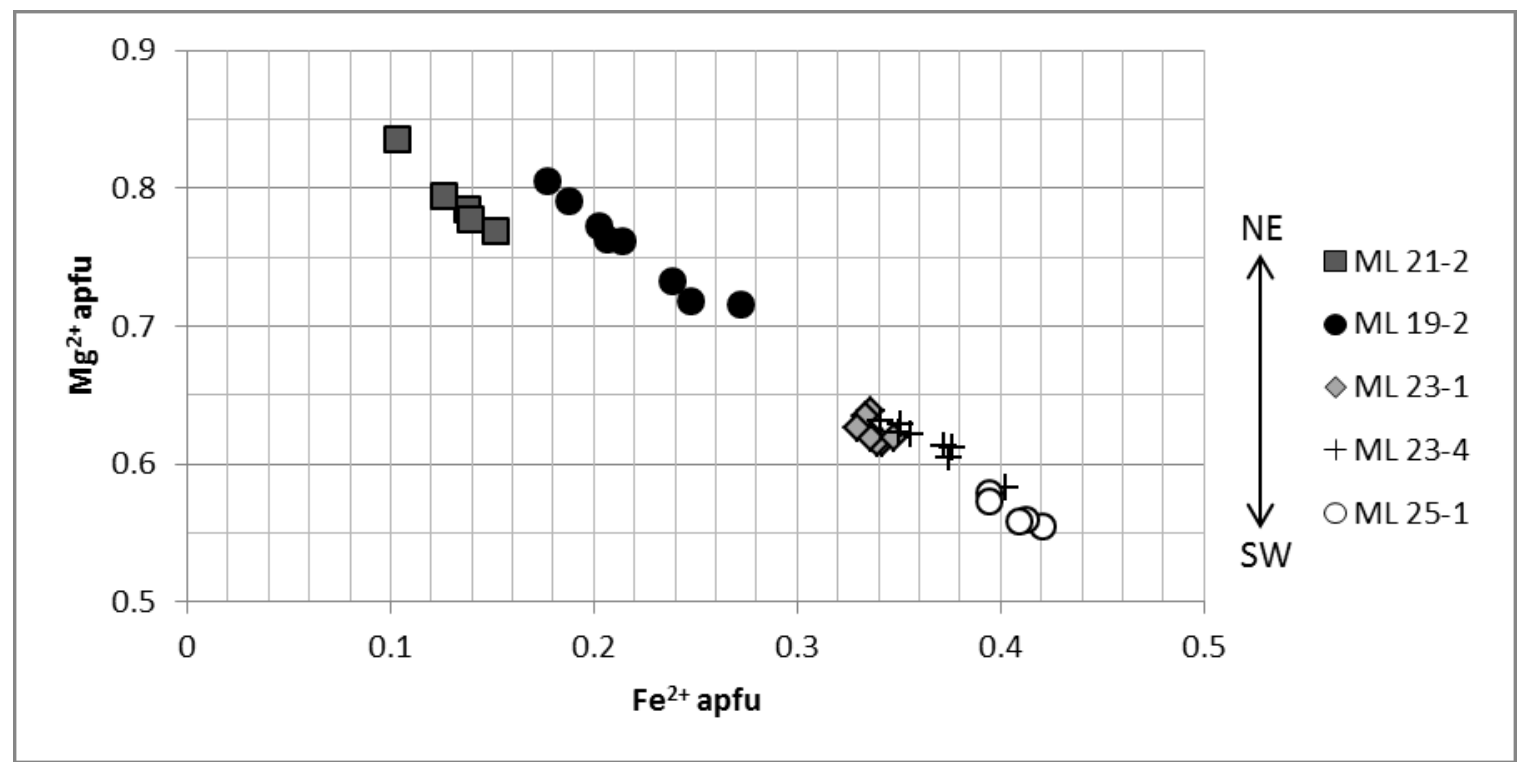

Figure 19. $\mathrm{Mg}^{2+}$ atoms per formula unit (apfu) versus $\mathrm{Fe}^{2+}$ apfu for calc-silicate hornfels clinopyroxenes. Samples are ordered in legend from most northeast (NE) to most southwest (SW).

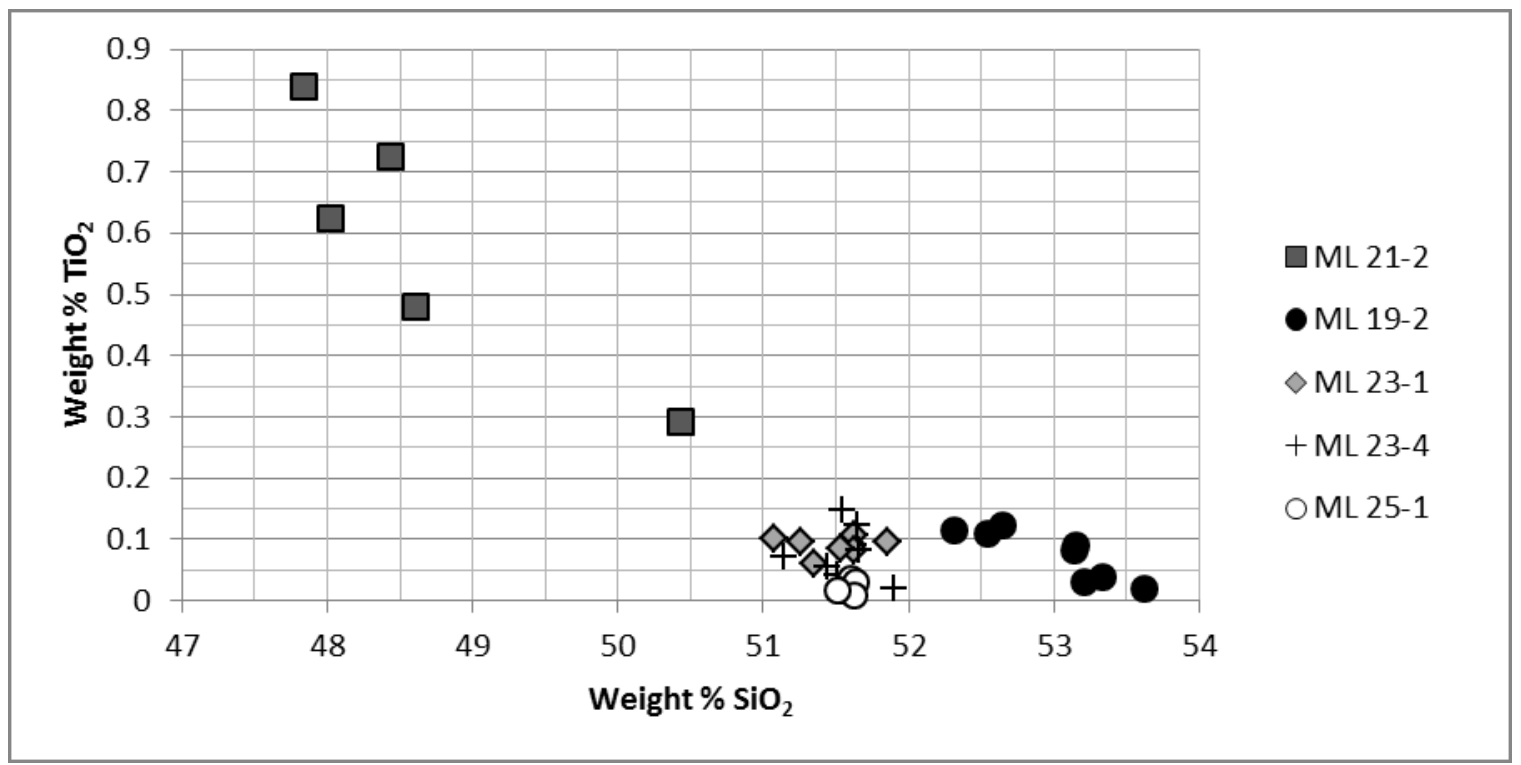

Figure 20. Weight percent $\mathrm{TiO}_{2}$ versus weight percent $\mathrm{SiO}_{2}$ in calc-silicate hornfels clinopyroxenes. 
Garnet Mineral Chemistry. Garnet in calc-silicate hornfels samples is most commonly present in $\mathrm{mm}$ - to $\mathrm{cm}$-wide pink to pinkish-beige bands of fine-grained garnet + plagioclase \pm quartz interbanded with green fine-grained clinopyroxene-rich bands. Garnet is predominantly grossular-andradite (aka "grandite") with large variability in $\mathrm{Fe}^{3+} /\left(\mathrm{Fe}^{3+}+\mathrm{Al}\right)$ between samples (Table B-4 and Fig. 21). Garnet from sample ML 25-1 is the most ferric iron rich (57-67\% andradite); garnet from sample ML 23-1 is the most aluminous and shows the most variation in garnet chemistry between bands $(58-91 \%$ grossular).

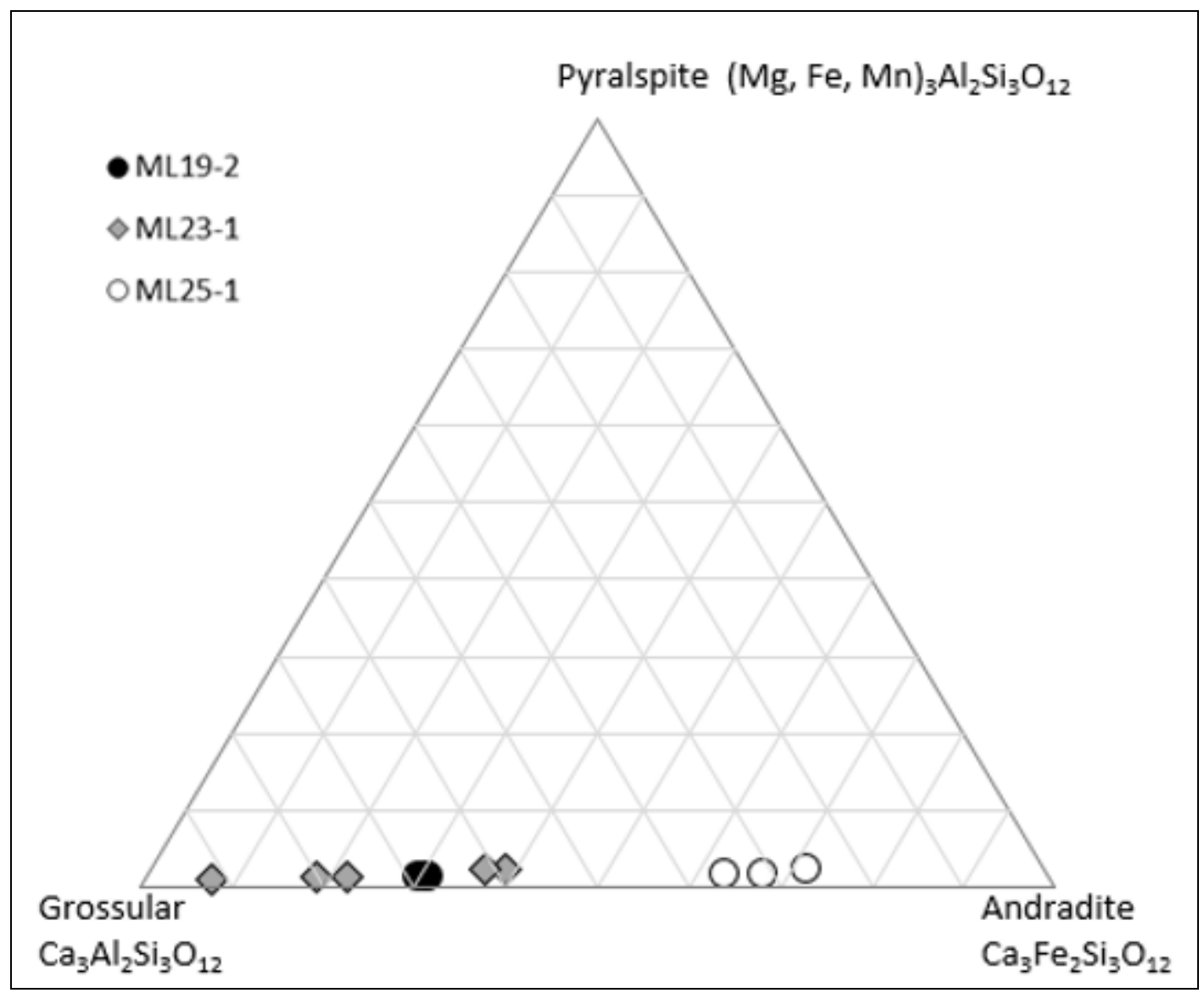

Figure 21. Calc-silicate hornfels garnet end-member composition. 
Plagioclase Mineral Chemistry. Calc-silicate hornfels samples ML 19-2, ML 23-4, and ML 25-1 were electron microprobed for plagioclase feldspar chemistry (Table B-5). Samples ML 19-2 and ML 25-1 are plagioclase + quartz + clinopyroxene hornfels with isolated streaks, clumps, and bands of fine-grained garnet. Plagioclase feldspar from samples ML 19-2 and ML 25-1 varies from An88 to An96. Sample ML 23-4 is clinopyroxene + plagioclase + quartz calc-silicate hornfels at contact with a granitic pegmatite. Plagioclase feldspar from this calc-silicate sample is less aluminous and more sodic with An22-43, Ab56-77, and Or0.90-2.5 (Fig. 22).

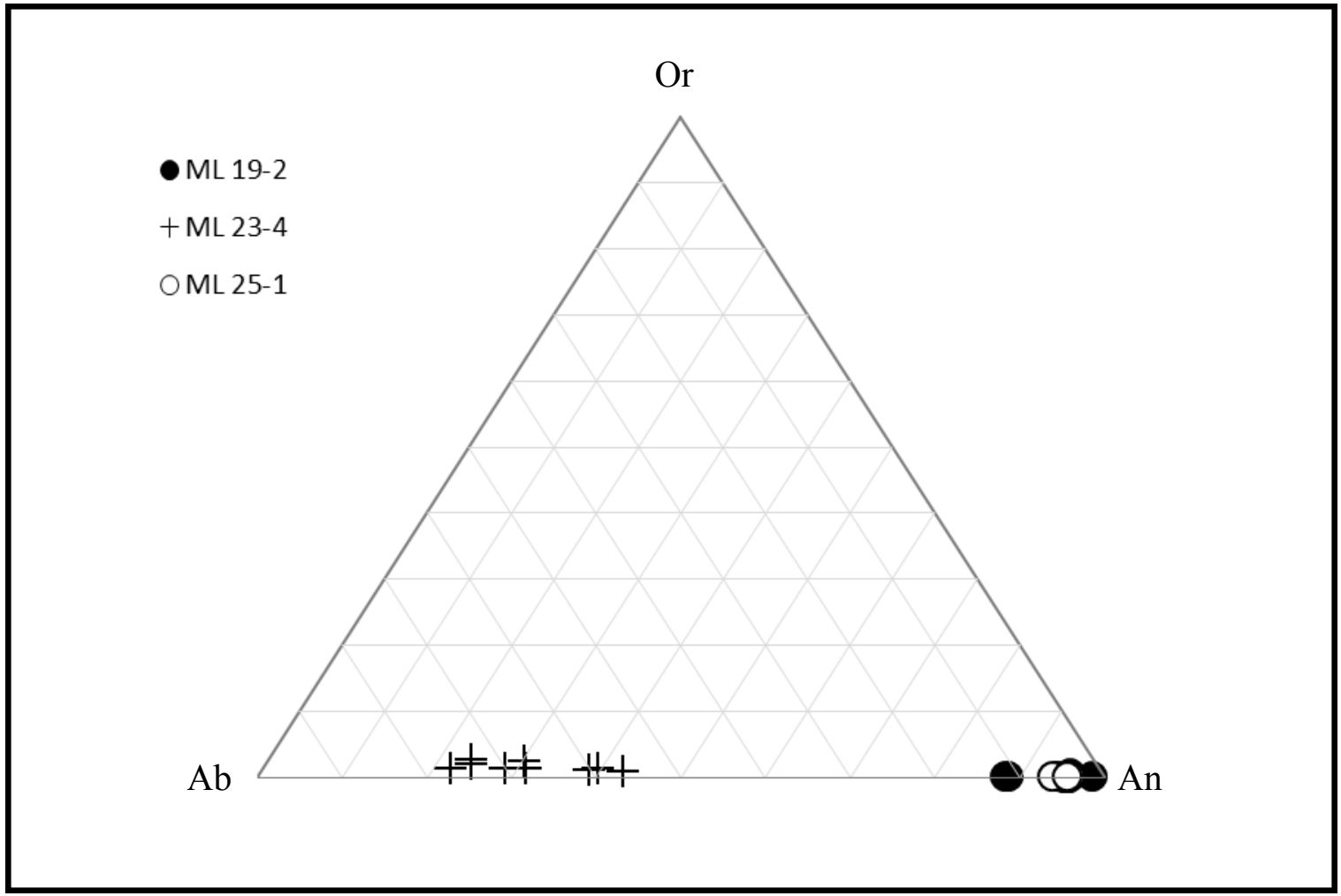

Figure 22. Calc-silicate hornfels plagioclase feldspar end member compositions. 


\section{Marble}

Marble varies from fine- to coarse-grained and off-white to light gray in color, with bands of pink, green, and orange alteration common. Three main marble bodies were studied in the northeastern screen: the northernmost at station ML 2 northeast of the lake, the southernmost at station ML 23, and the largest marble body at station ML 46 centrally located on the south shore of May Lake (see Methods section Fig. 6, page 21). ML 2 and ML 23 occur as finer-grained lenses less than a few meters wide and closely interlayered with calc-silicate (ML 2: Fig. 18A). However, ML 46 is approximately $20 \mathrm{~m}$ by $26 \mathrm{~m}$ and consists of light gray coarse-grained marble surrounded by heavily folded green and white calc-silicate hornfels and dark gray metapelite (Fig. 18B). Wollastonite, green clinopyroxene, and red-brown garnet form mineralogically distinct skarn zones at the marble-metapelite contact.

Marble samples from stations ML 2 and ML 23 were analyzed by petrographic microscope. Sample ML 2-5 is a coarse-grained white marble adjacent to granitic pegmatite and calc-silicate hornfels and consists of calcite with minor clinopyroxene; garnet and $>1 \mathrm{~cm}$ long epidote are present in skarn at the contact between the marble and the granitic pegmatite. Sample ML 23-2 is a medium-grained off-white to light grey marble consisting of calcite + phlogopite + chondrodite + opaques.

\section{Skarn}

Centimeter-scale vein, magmatic, and metamorphic skarn occur ubiquitously in the northeastern screen where marbles or calc-silicate rocks are in contact with silica-rich metamorphic or igneous rock. Zoning of clinopyroxene, epidote, garnet, and other skarn 
minerals is common at these contacts. Endoskarn and exoskarn samples from four skarn locations from the northeastern screen (locations ML 2, ML 21, ML 26, and ML 28 on Fig. 6, p. 21; Table 4) were analyzed for mineral assemblages, reaction textures, and mineral chemistry. The first three locations are $\mathrm{cm}$ - to dm- scale skarn bodies located in the north (ML 1 and ML 21) and north-central (ML 26) sections of the northeastern screen, near May Lake. The fourth skarn formation studied, at station ML 28, is a $\sim 2 \mathrm{~m} \mathrm{x}$ $5 \mathrm{~m}$ oblong-shaped skarn body at the contact between the Glen Aulin granodiorite and a folded calc-silicate raft within the granodiorite (Tables 4 and 5). This massive magmatic skarn, termed "megaskarn," outcrops for several meters on the hillside below the central section of the IPS less than $10 \mathrm{~m}$ from the southern contact of the IPS with the Tuolumne Intrusive Suite.

Common skarn minerals at these locations include clinopyroxene, epidote, and garnet. A reaction texture suggesting epidote replacing plagioclase can be seen in thin sections of endoskarn from samples ML 21-3 and ML 28-7B and exoskarn from sample ML 2-1 (ML 21-3: Fig. 23). Plagioclase and epidote in sample ML 21-3 which exhibit this texture were microprobed (Table B-6); plagioclase is albite (An1) and epidote is epidote-clinozoisite with $32 \%$ clinozoisite. 
Table 4. Descriptions of skarn samples from the northeastern screen.

Sample Name Description

ML 2-1 Garnet and epidote-bearing exoskarn on green and pink banded calcsilicate hornfels at contact with metapelite.

ML 21-3 Epidote-bearing endoskarn on K-feldspar-rich granitic pegmatite at contact with calc-silicate hornfels.

ML 26-1 Zoned (epidote/calcite/garnet) exoskarn on green and pink banded calcsilicate hornfels.

ML 28-2* Exoskarn from garnet zone with garnets over $5 \mathrm{~cm}$ in diameter.

ML 28-3* Exoskarn from epidote zone with bladed epidote up to $4.5 \mathrm{~cm}$ in length.

ML 28-5* Exoskarn from garnet zone with medium-grained (1-2 mm) garnets.

ML 28-6* Endoskarn surrounding a calc-silicate xenolith within granodiorite.

ML 28-7A* Unaltered granodiorite to endoskarn contact.

ML 28-7B* Endoskarn/exoskarn contact.

ML 28-11* Exoskarn with garnet.

ML 28-12A* Exoskarn with clinopyroxene, epidote blades, and garnet.

ML 28-12B* Endoskarn/exoskarn contact.

*See Table 5 for mineralogy of ML 28 
Table 5. Mineralogy of station ML 28 skarn formation.

\begin{tabular}{|c|c|c|c|c|c|c|c|c|c|}
\hline Rock type & Qtz & Cpx & Grt & $\mathrm{Ep}$ & $\mathrm{Bt}$ & $\mathrm{Hbl}$ & $\mathrm{Pl}$ & Ksp & Ttn \\
\hline $\begin{array}{l}\text { ML } 28 \text { calc- } \\
\text { silicate }\end{array}$ & $\mathrm{x}$ & $\mathrm{X}$ & & & & $\mathrm{x}^{*}$ & $\mathrm{x}$ & & \\
\hline ML 28 exoskarn & $\mathrm{x}$ & $\mathrm{x}$ & $\mathrm{x}$ & $\mathrm{x}$ & & & & & \\
\hline ML 28 endoskarn & $\mathrm{x}$ & $\mathrm{x}$ & $x^{*}$ & $\mathrm{x}$ & & & $\mathrm{x}$ & & $\mathrm{x}$ \\
\hline $\begin{array}{l}\text { ML } 28 \\
\text { granodiorite }\end{array}$ & $\mathrm{x}$ & & & & $\mathrm{x}$ & $\mathrm{x}$ & $\mathrm{x}$ & $\mathrm{x}$ & \\
\hline
\end{tabular}

*Only observed in sample ML 28-6 (endoskarn surrounding calc-silicate xenolith).

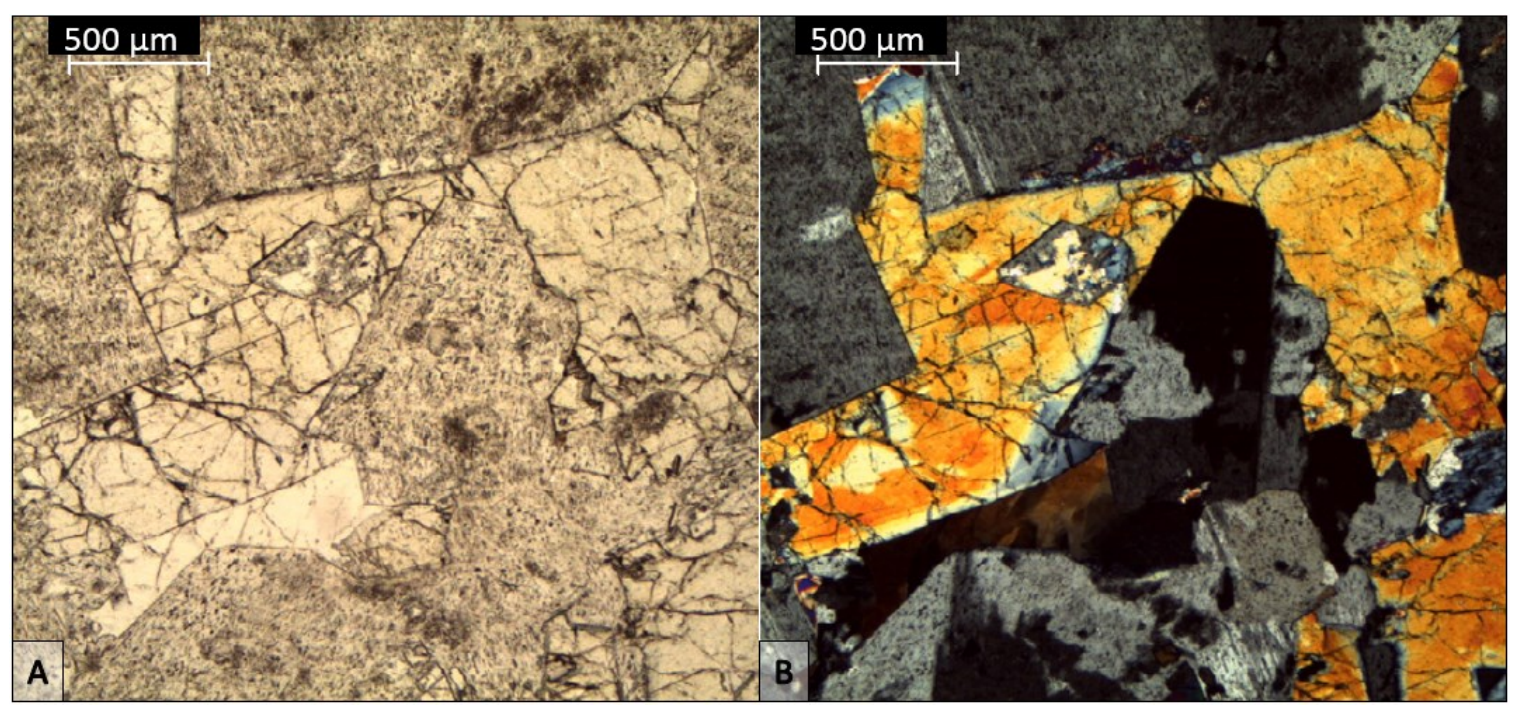

Figure 23. Photomicrographs of sample ML 21-3 in plane polarized (A) and cross polarized (B) light. Cloudy white mineral is plagioclase. Moderately birefringent prismatic mineral is epidote.

The megaskarn at station ML 28 consists of zones of pegmatitic garnet, epidote, and quartz. Distinct epidote and garnet exoskarn zones reach up to $0.5 \mathrm{~m}$ each in thickness within this megaskarn, with epidote blades up to $4.5 \mathrm{~cm}$ in length and garnet crystals over $5 \mathrm{~cm}$ in diameter (Figs. 24A and B, respectively). 


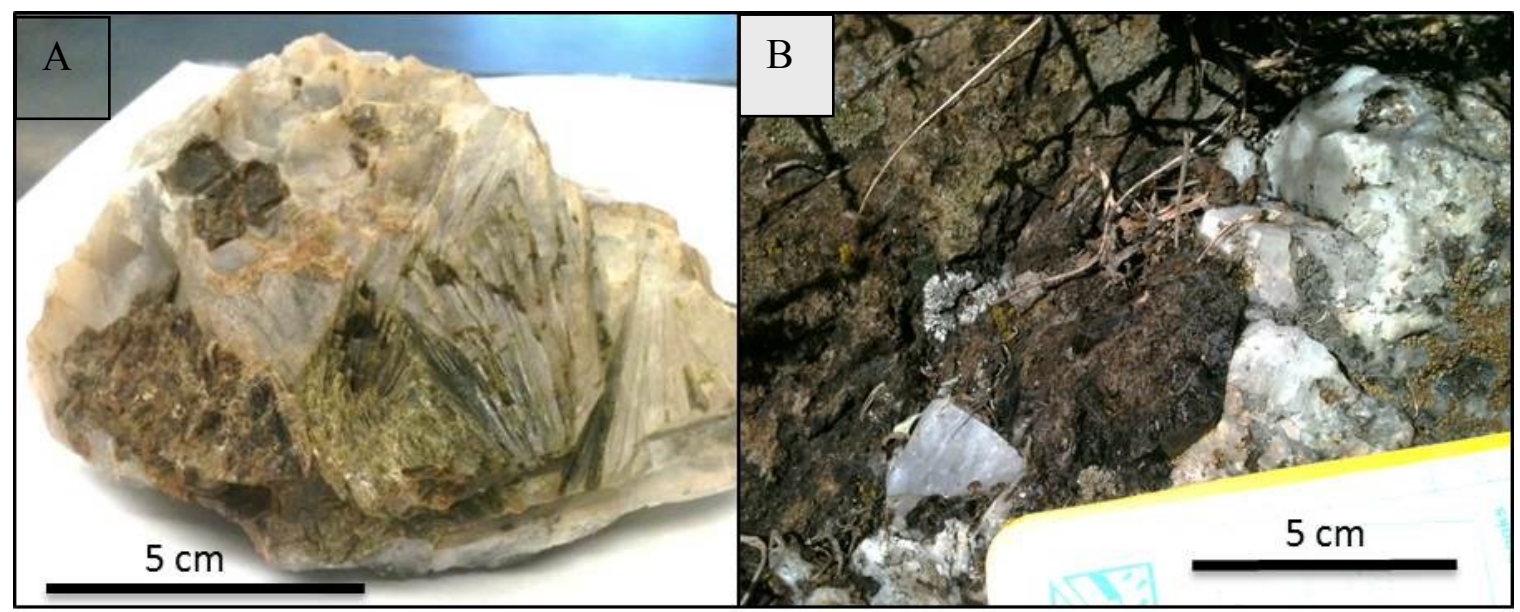

Figure 24. Skarn minerals from station ML 28. A) $4 \mathrm{~cm}$ long green epidote blades and $\sim 1 \mathrm{~cm}$ diameter brownish-red garnets within quartz. B) Weathered, brownish-red garnet within quartz. Garnet (center) is in contact with green calc-silicate raft (upper left).

A $\sim 5 \mathrm{~cm}$ zone of endoskarn is present at the contact between granodiorite and exoskarn at ML 28. Transition from granodiorite to endoskarn is sharp and clearly visible to the eye due to the color change from brown/black hornblende and biotite in the granitic rock to green clinopyroxene in the metamorphic rock (Fig. 25); quartz + plagioclase + hornblende + biotite + chlorite-bearing granodiorite transitions to plagioclase + clinopyroxene + quartz + titanite + epidote-bearing endoskarn. Clinopyroxene from the endoskarn and hornblende from the granodiorite were microprobed (Tables B-7 and B-8, respectively). Mineral textures suggest diopside replaced hornblende in the endoskarn. 


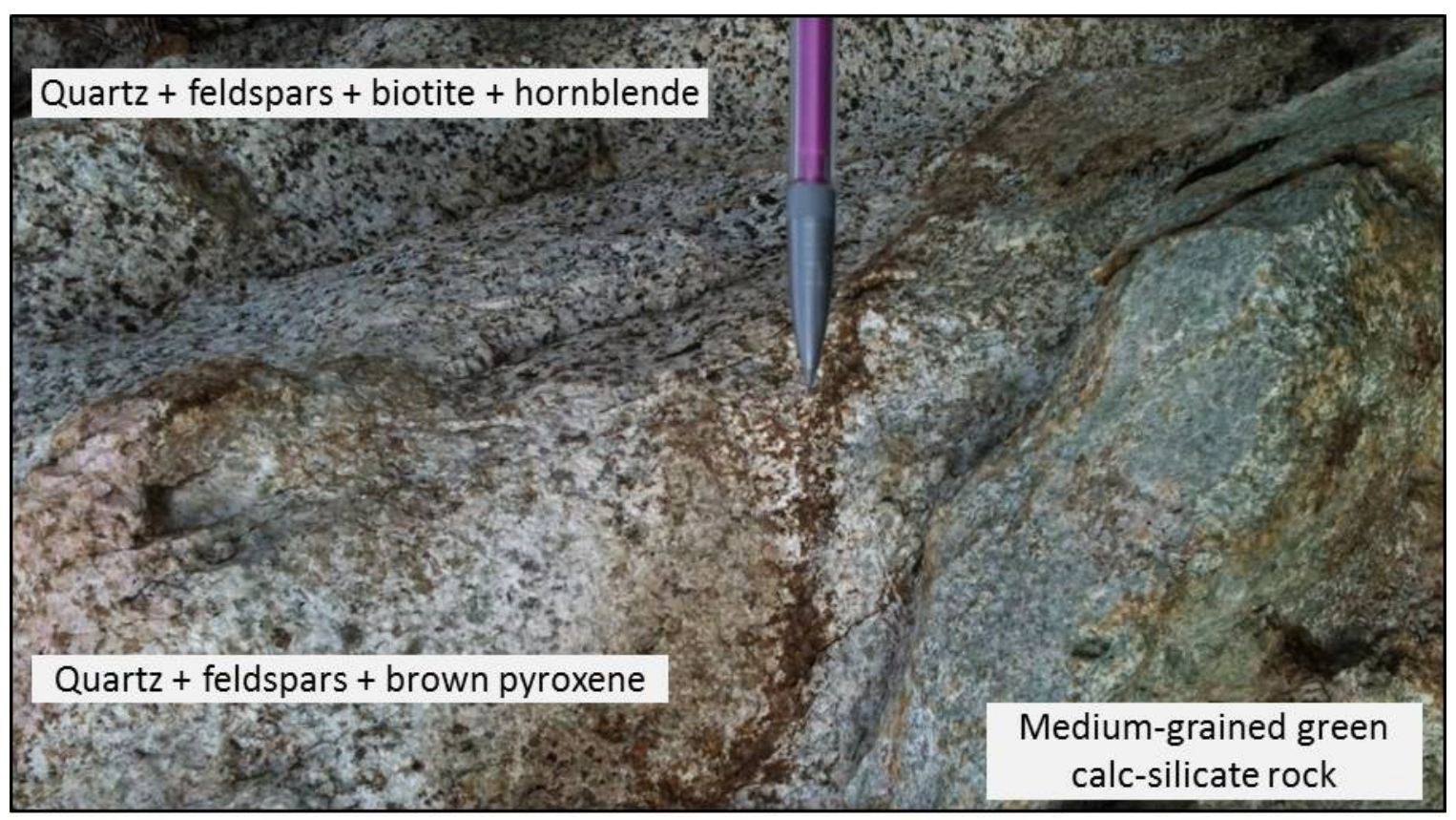

Figure 25. Alteration of granodiorite to endoskarn at ML 28 contact. Glen Aulin granodiorite (upper left corner) and endoskarn (lower left corner and middle), with pencil for scale.

Sample ML 28-6 consists of a blue calc-silicate hornfels xenolith with a dark, amphibole-rich core surrounded by Glen Aulin granodioritic endoskarn near the exoskarn at ML 28 (Fig. 26). The granodiorite endoskarn surrounding the xenolith has brown mineral alteration. Clinopyroxene, garnet, and plagioclase from the endoskarn, clinopyroxene and plagioclase from the blue hornfels, and hornblende and plagioclase from the hornblende-rich core were microprobed (Table B-9). Clinopyroxenes and plagioclases within the endoskarn have similar chemistry to those minerals within the hornfels: 59-63\% diopside and An32-46, respectively. Plagioclase within the hornblende-rich core, however, is relatively more calcic (An61-77). Hornblende from the 
hornfels is more aluminum-rich and calcic than the igneous hornblende from Glen Aulin granodiorite sample ML 28-7A (Fig. 27, Tables B-8 and B-9).

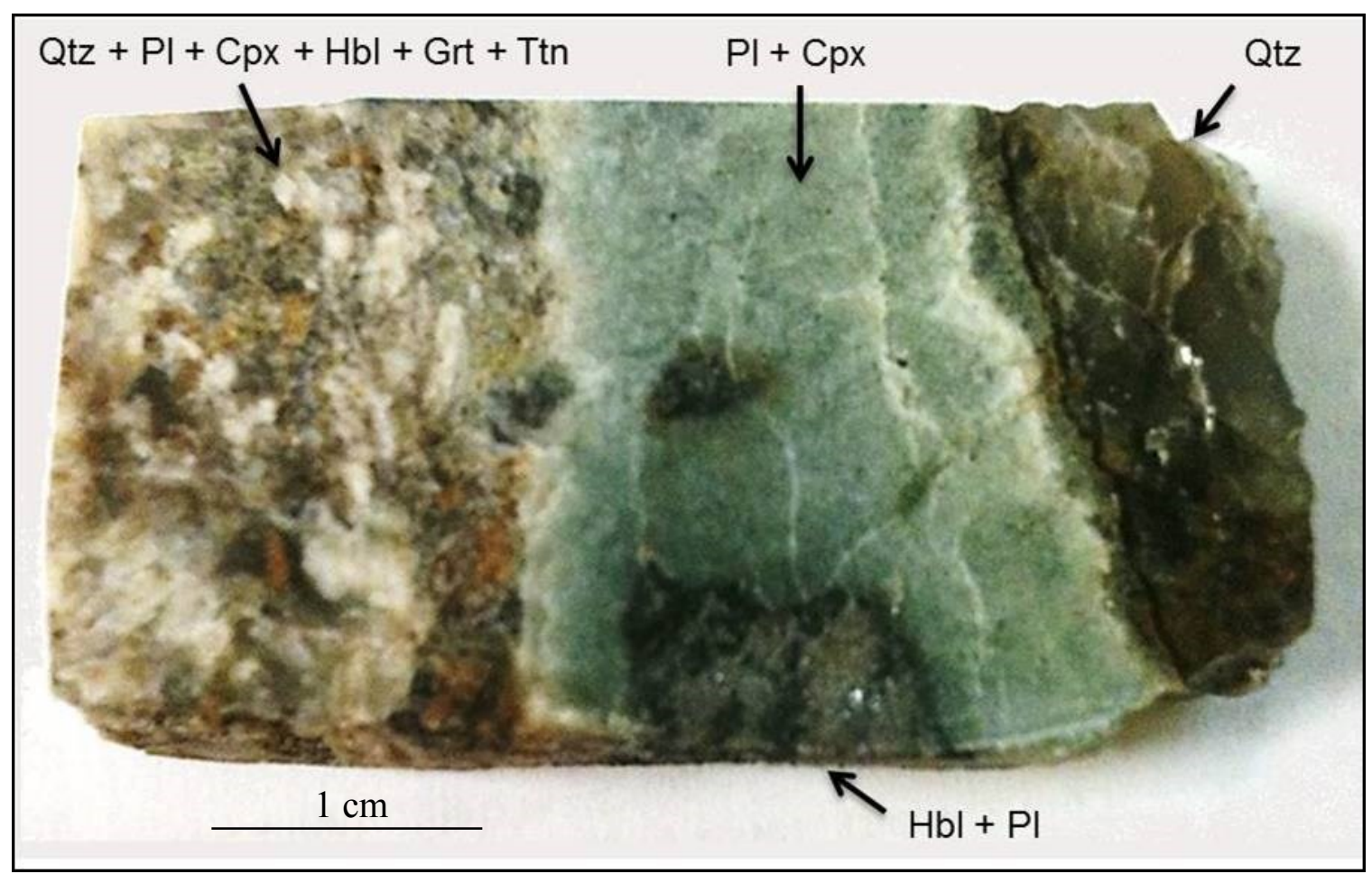

Figure 26. Hand sample of sample ML 28-6. Blue calc-silicate xenolith within endoskarn of Glen Aulin granodiorite. 


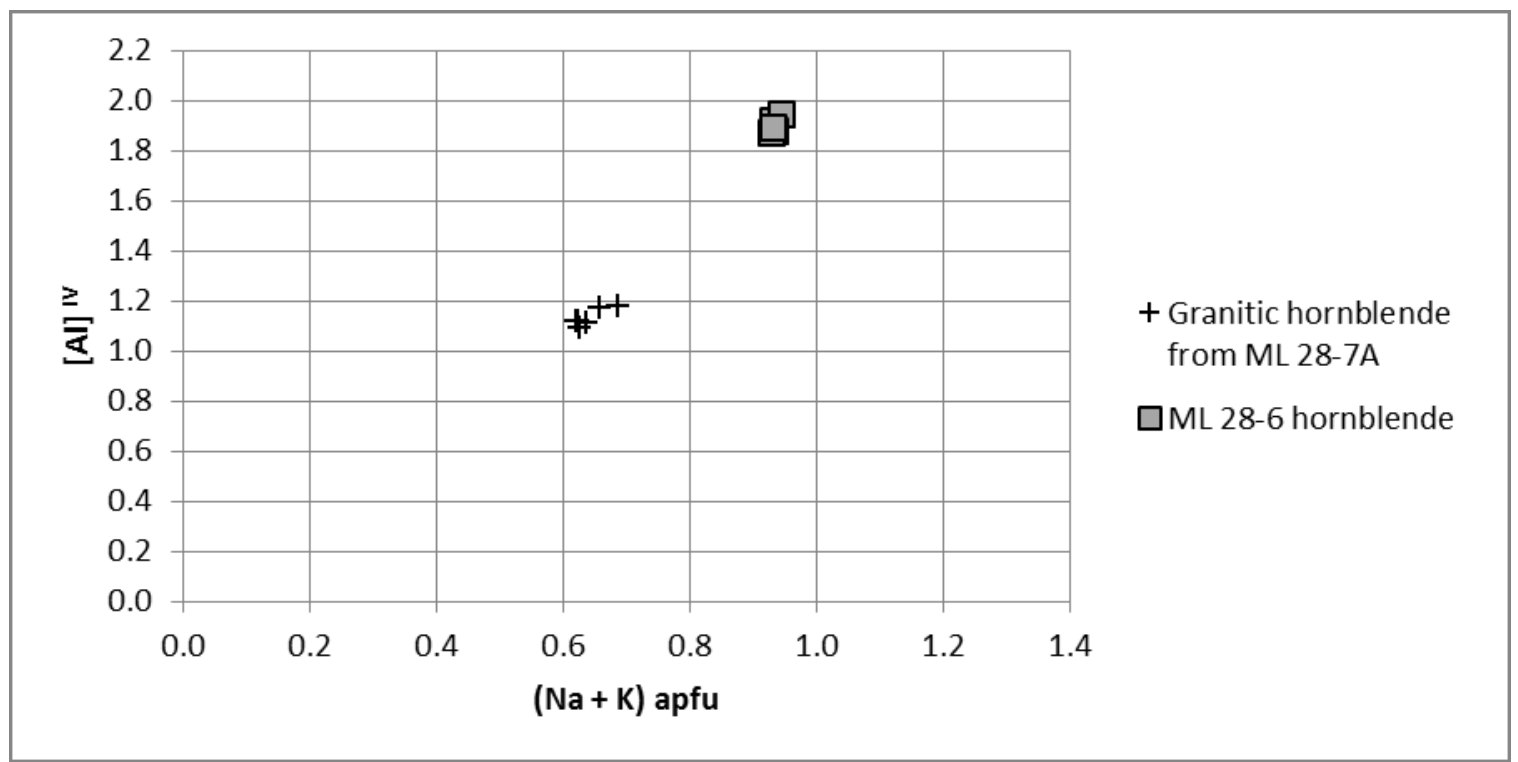

Figure 27. Tetrahedral site $\mathrm{Al}$ atoms per formula unit (apfu) versus $\mathrm{Na}+\mathrm{K}$ apfu in hornblende from station ML 28. Glen Aulin granodiorite (sample ML 28-7A) hornblende compared to hornblende from hornblende-rich core within hornfels xenolith (ML 28-6).

Clinopyroxene Mineral Chemistry. Four endoskarn samples (ML 28-6, ML 28-7A, ML 28-7B, and ML 28-12B) and three exoskarn samples (ML 28-3, ML 28-5, and ML 28-12A) from station ML 28 were analyzed for clinopyroxene chemistry. Results of electron microprobe analysis show little distinction in chemical compositions of clinopyroxenes from different sections of the large skarn formation at station ML 28; clinopyroxenes are diopside-hedenbergite with 63-71\% diopside (Tables B-7 and B-9).

Epidote Mineral Chemistry. Microprobe analyses were obtained for epidote from two endoskarn samples (ML 21-3, ML 28-7B) and two exoskarn samples (ML 28-3, ML 28-5) from the northeastern screen. ML 21-3 is coarse-grained endoskarn formed at the contact between marble and a granitic pegmatite at the northernmost end of the May Lake IPS. ML 28-7B is medium-grained endoskarn $5 \mathrm{~cm}$ from the endoskarn-exoskarn 
contact. ML 28-3 is medium-grained exoskarn sampled approximately $1 \mathrm{~m}$ from the calc-silicate rock-exoskarn contact. ML 28-5 is medium-grained exoskarn $21 \mathrm{~cm}$ from the endoskarn-granodiorite contact. Epidote from station ML 28 is $21-36 \%$ clinozoisite. No significant difference in epidote mineral chemistry was observed between endoskarn and exoskarn minerals (Fig. 28 and Table B-10).

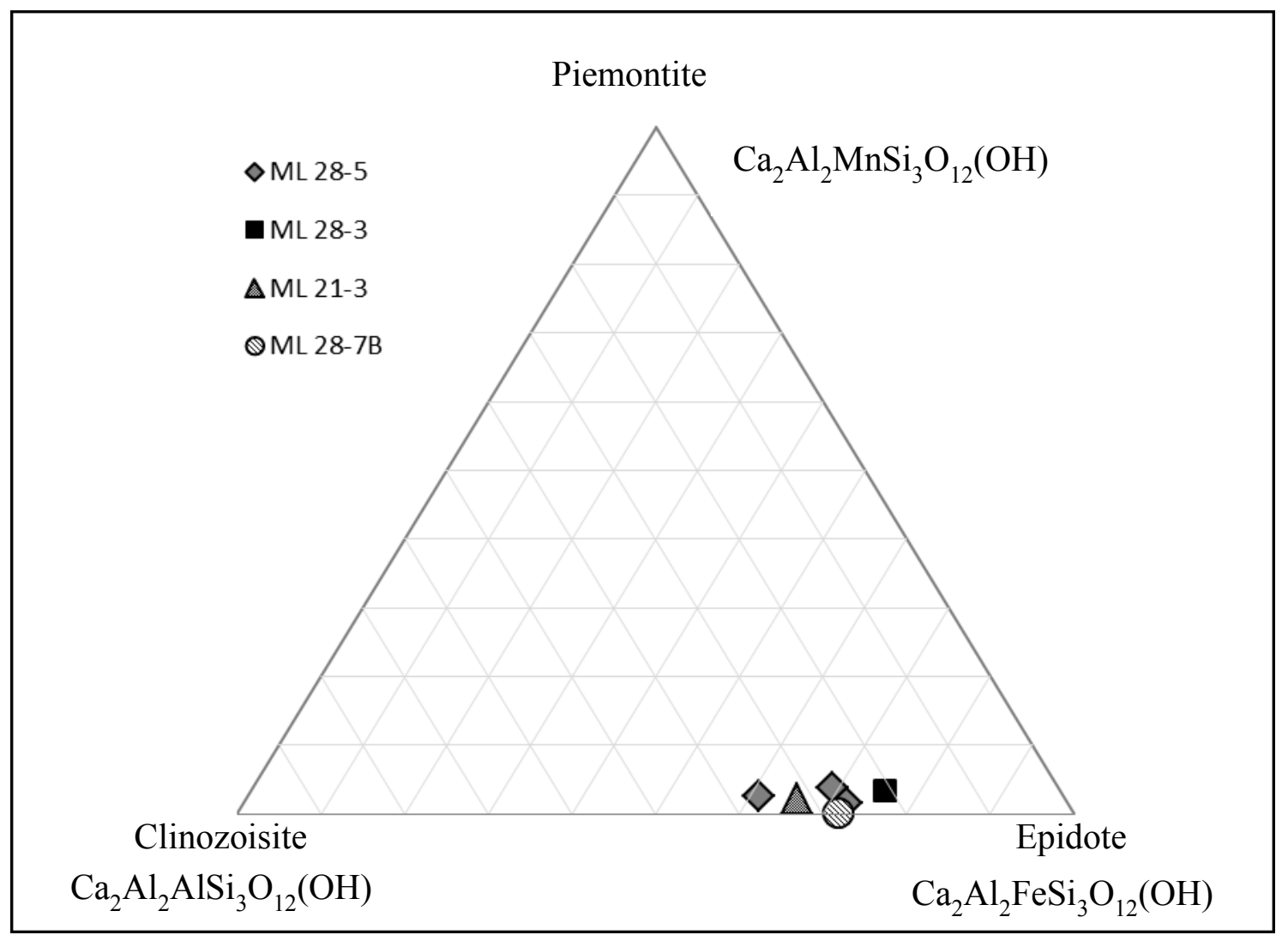

Figure 28. Skarn epidote mineral chemistry. ML 28-3 and ML 28-5 are exoskarn samples and ML 21-3 and ML 28-7B are endoskarn samples.

Garnet Mineral Chemistry. Garnets in exoskarn samples ML 28-2 and ML 28-5 and endoskarn sample ML 28-6 were selected for mineral chemical analysis by electron 
microprobe in order to assess chemical variations due to mineral size and distance from the endoskarn-exoskarn contact, and to compare endoskarn to exoskarn.

Exoskarn sample ML 28-2, taken approximately $1 \mathrm{~m}$ from the endoskarn-exoskarn contact between the megaskarn and the TIS, consists of a single 3-cm diameter garnet surrounded by quartz. Exoskarn sample ML 28-5, taken $21 \mathrm{~cm}$ from the endoskarnexoskarn contact, consists of medium-grained garnet ( $\sim 1$ to $2 \mathrm{~mm}$ in diameter) in assemblage with clinopyroxene and quartz. Endoskarn sample ML 28-6 consists of finegrained garnet in assemblage with quartz + plagioclase + clinopyroxene + hornblende + titanite within the Glen Aulin granodiorite surrounding a calc-silicate xenolith.

Average values of garnet chemical compositions from the exoskarn samples are similar with $\sim 52-53 \%$ Grs; however, more chemical variation is observed in the $3-\mathrm{cm}$ garnet of exoskarn sample ML 28-2 which ranges from 34-61\% Grs. Endoskarn garnet from sample ML 28-6 is within the range of the ML 28-2 exoskarn garnet with $44 \%$ Grs (Fig. 29 and Table B-11). Light and dark concentric zones are visible in back scattered electron images of the garnet (Fig. 30). Core to rim analyses of this large garnet reveal distinct chemical zoning with oscillation in Fe and Al between zones (Fig. 31). 


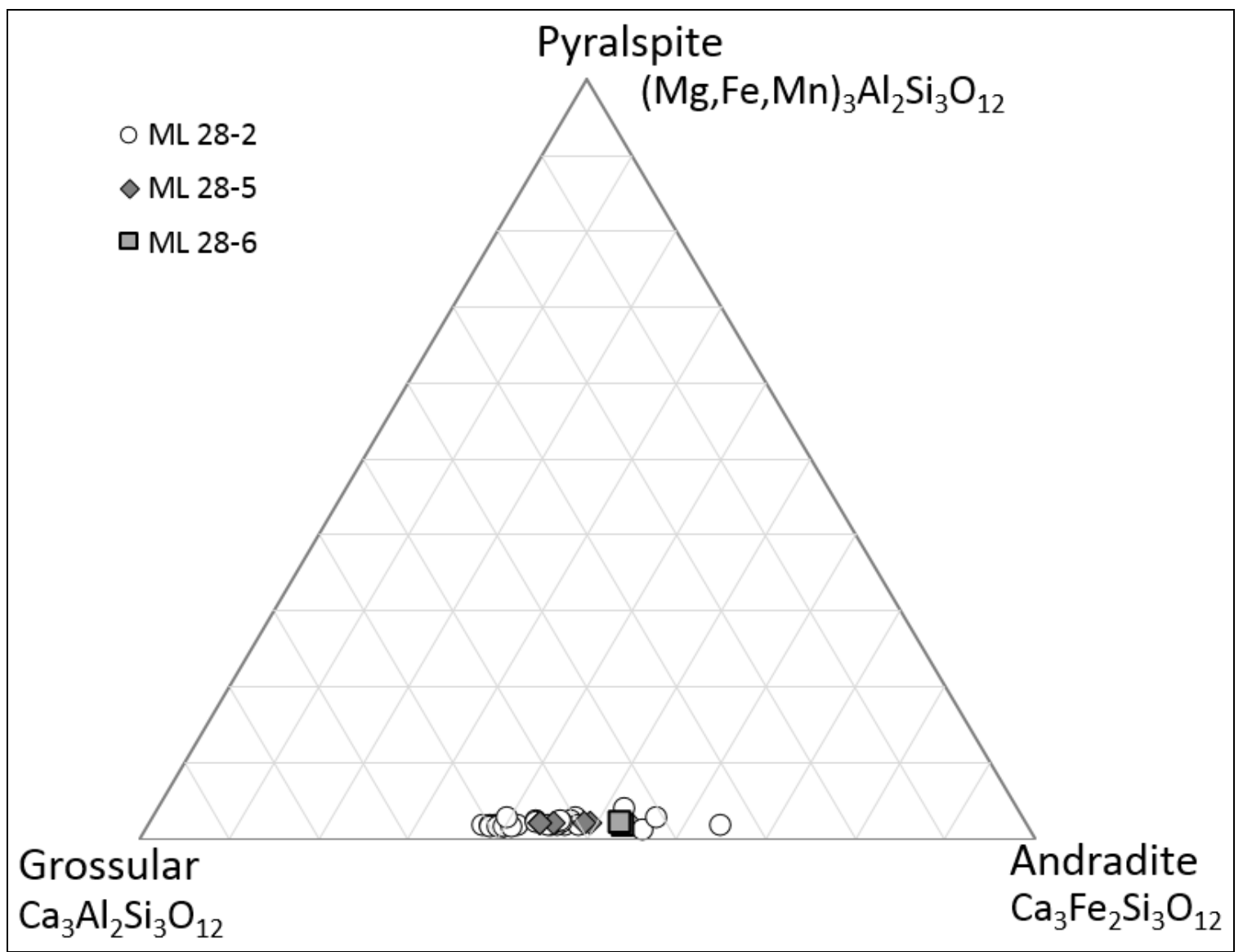

Figure 29. Skarn garnet mineral chemistry. ML 28-2 and ML 28-5 are exoskarn samples and ML 28-6 is an endoskarn sample. 


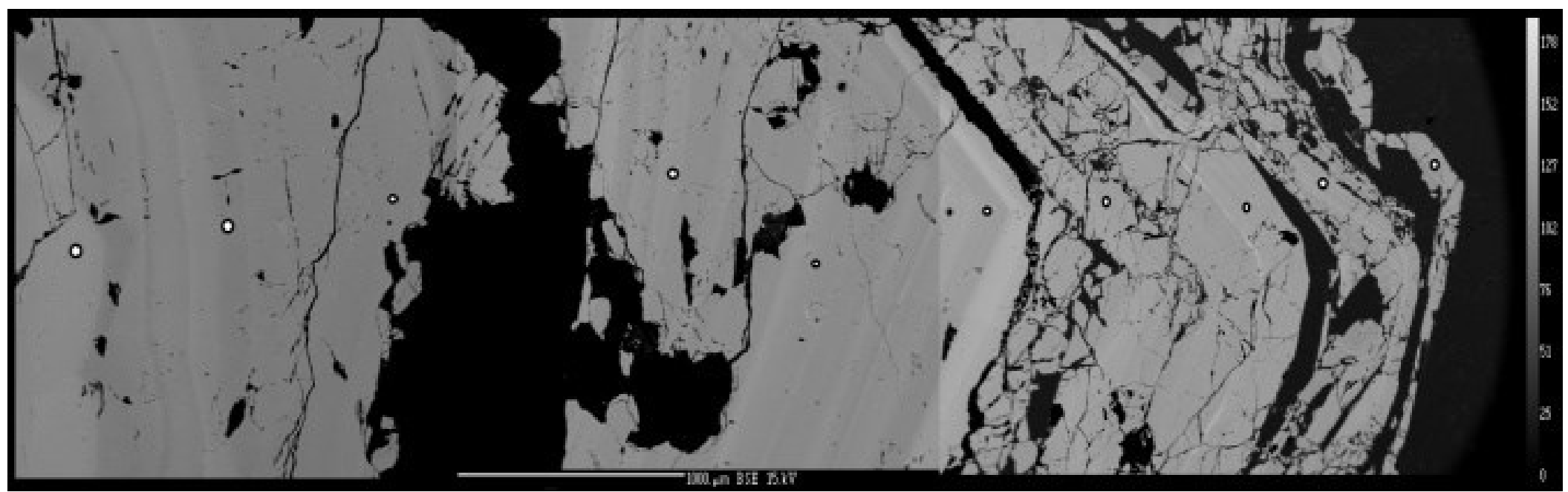

Figure 30. Back-scattered electron images of outer rim of zoned 3-cm diameter garnet from exoskarn sample ML 28-2. Small circles indicate electron microprobe spot locations. Scale bar at the bottom is $1 \mathrm{~mm}$. 


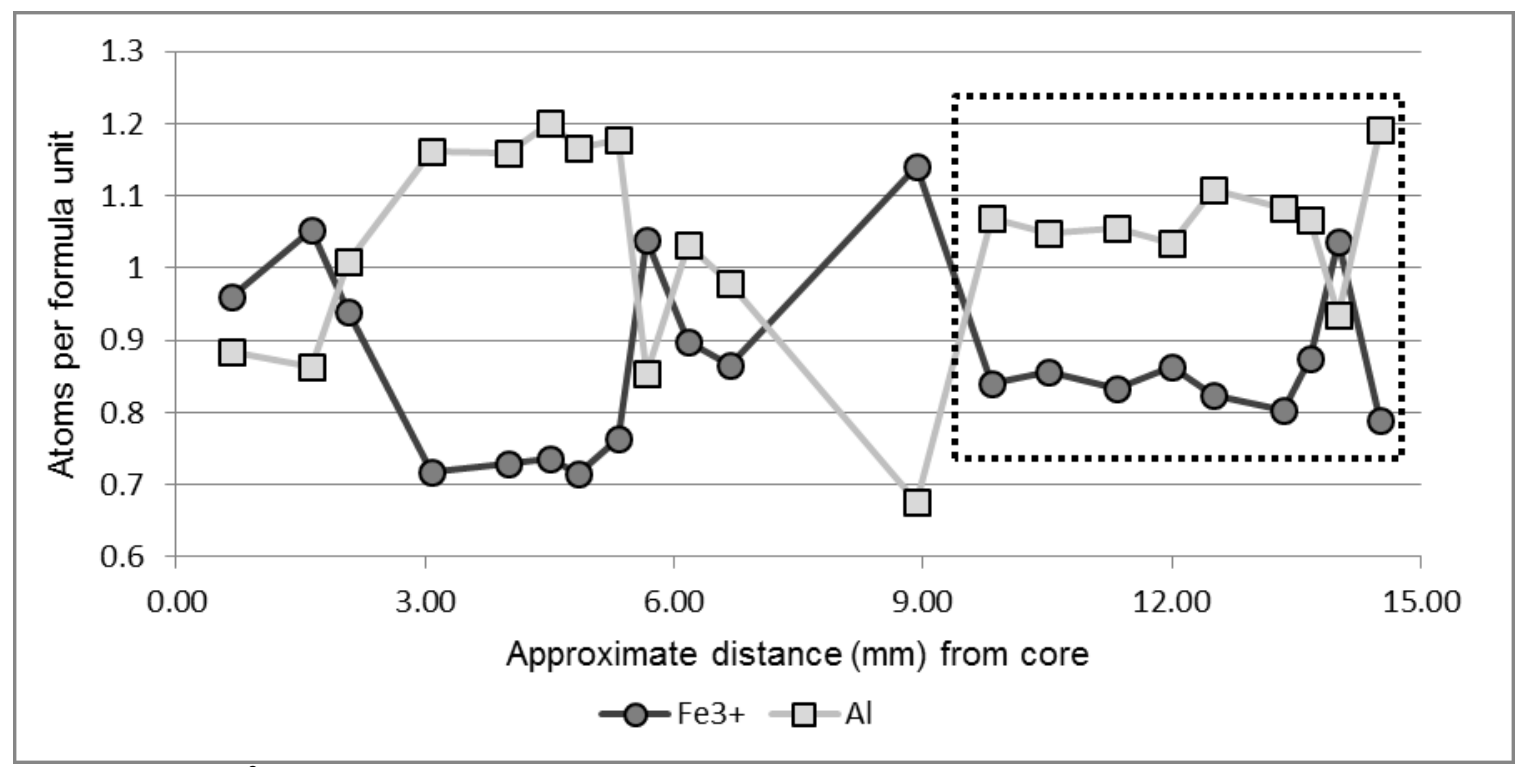

Figure 31. $\mathrm{Fe}^{3+}$ and $\mathrm{Al}$ atoms per formula unit (apfu) from core to rim of zoned 3-cm diameter skarn garnet from sample ML 28-2. Dotted box outlines location of electron microprobe spots shown in Figure 30.

\section{Metamorphosed Mafic Dikes}

Three fine- to medium-grained, dark grey, biotite-rich metamorphosed mafic dikes from the northeastern screen were studied in thin section and contain the mineral assemblage biotite + hornblende + plagioclase + quartz + opaque minerals (Table 6$)$. These dikes are aluminous and mafic-rich with up to $30 \%$ biotite, $20 \%$ hornblende, and opaque minerals often seen as inclusions within the biotite. Plagioclase makes up 20$40 \%$ of the mineral assemblage. 
Table 6. Metamorphosed mafic dike petrographic descriptions.

\begin{tabular}{|c|c|c|c|c|c|c|c|c|c|}
\hline Sample & Description & Qtz & Cpx & $\mathrm{Bt}$ & Chl & $\mathrm{Hbl}$ & Crd & $\mathrm{Pl}$ & opq \\
\hline ML 4-3 & $\begin{array}{l}\text { Amphibolite dike bearing coarse- } \\
\text { grained biotite and quartz, near } \\
\text { contact with quartzite. }\end{array}$ & $\mathrm{x}$ & $\mathrm{x}$ & $\mathrm{x}$ & & $\mathrm{x}$ & & $\mathrm{x}$ & $\mathrm{x}$ \\
\hline ML 8-2 & Schistose mafic dike. & $\mathrm{x}$ & & $\mathrm{x}$ & & & $\mathrm{x}$ & $\mathrm{x}$ & \\
\hline ML 11-1 & $\begin{array}{l}\sim 10 \text { m wide, fine-grained, greenish- } \\
\text { grey, micaceous amphibolite dike. }\end{array}$ & $\mathrm{x}$ & & $\mathrm{x}$ & $\mathrm{x}$ & $\mathrm{x}$ & & & \\
\hline
\end{tabular}

\section{Granitic Pegmatites}

Granitic pegmatites were sampled at station ML 1 at the north shore of May Lake, station ML 21 near the northern end of the northeastern screen, and in the central section of the northeastern screen at station ML 23. The granitic pegmatite sampled at station ML 1 is approximately 0.5 meter wide and several meters long with quartz, $\mathrm{K}$-feldspar, white mica, radial prismatic black tourmaline, and bladed green epidote. The granitic pegmatites at stations ML 21 and ML 23 are primarily quartz, plagioclase, and K-feldspar in contact with calc-silicate hornfels consisting of plagioclase, diopside, and quartz. Skarn is present at the contact between the pegmatite and calc-silicate hornfels at station ML 21. Based on electron microprobe analysis, K-feldspar from granitic pegmatites at stations ML 21 and ML 23 is Or90-91 and Ab9-10, and plagioclase feldspar from the granitic pegmatite at station ML 23 is Ab72 An26 Or2 (Table B-12). 


\section{Southwestern Screen}

\section{Silicic and Aluminous Metasedimentary Units}

An elongate swath of fine-grained, light grey metapelitic hornfels separates the two marble bodies of the southwestern screen. Metavolcanic rock is very rare in either screen, and was only found as an isolated blocky mass of less than a few meters in width adjacent to the marble at station T5. A band of quartzite extends for $34 \mathrm{~m}$ through the southeastern-most marble body from stations ML 59 to ML 59.5. This band is from 2 to $6 \mathrm{~m}$ thick and tapers sharply at each end into the surrounding granite. Pods of metapelitic rock are scattered throughout the quartzite band.

\section{Marble}

Extensive sections of medium- to coarse-grained, white to light grey marble make up the majority of the southwestern screen (see Structure of the May Lake IPS Figs. 15, $16 \mathrm{~A}$, and $16 \mathrm{~B}$, pages 34 and 35 ). The marble is typically $\sim 95 \%$ carbonate by visual estimation, intermittently foliated, and outcrops as two large bodies each hundreds of meters in length and tens of meters in width. Minor minerals found in the marble include streaked graphite, bladed wollastonite, brucite, and phlogopite. Graphite streaks are common. Wollastonite is prevalent at stations ML 53, ML 56, and ML 57. Marble adjacent to metamorphosed mafic dikes typically shows iron oxidation at the dike contact extending a few $\mathrm{mm}$ to $\mathrm{cm}$ into the marble. Calc-silicate rock is only present as boudins and small blob-like bodies within the marble and is a very minor component of the screen. 
Seven marble samples from the southwest screen were studied in thin section (Table 7). These rocks are predominantly clinopyroxene-marble, graphite-marble, or chondrodite-marble. Calcite is coarse-grained. Chondrodite is fine-grained, granular, and reddish-brown in color. Accessory minerals present include wollastonite, brucite, and opaque minerals.

Table 7. Rock descriptions and mineral assemblages for southwestern marble samples.

\begin{tabular}{|c|c|c|c|c|c|c|c|c|c|c|}
\hline $\begin{array}{l}\text { Sample } \\
\text { ID }\end{array}$ & Description & Cpx & Grt & Phl & Cal & Wo & Chn & $\mathrm{Brc}$ & Gr* & opq \\
\hline ML 29-1 & $\begin{array}{l}\text { Coarse-grained, homogenous, } \\
\text { white marble ( }>99 \% \text { calcite })\end{array}$ & $\mathrm{x}$ & & & $\mathrm{x}$ & & & & & \\
\hline ML 30-1 & $\begin{array}{l}\text { Coarse-grained, homogenous, } \\
\text { white marble ( }>99 \% \text { calcite) }\end{array}$ & & & & $\mathrm{X}$ & & $\mathrm{x}$ & & & \\
\hline T1-1 & $\begin{array}{l}\text { Coarse-grained marble streaked } \\
\text { with graphite }\end{array}$ & & & & $\mathrm{x}$ & & & & $\mathrm{x}$ & $\mathrm{X}$ \\
\hline T3-2 & Marble nearest skarn sample T3-1 & $\mathrm{x}$ & $\mathrm{x}$ & & $\mathrm{x}$ & $\mathrm{x}$ & $\mathrm{x}$ & $\mathrm{x}$ & & $\mathrm{x}$ \\
\hline T4-1 & $\begin{array}{l}\text { Coarse-grained white marble with } \\
\text { minor graphite }\end{array}$ & $\mathrm{x}$ & & & $\mathrm{X}$ & & & & $\mathrm{x}$ & $\mathrm{x}$ \\
\hline T5-1 & $\begin{array}{l}\text { Coarse-grained white marble with } \\
\text { minor red minerals }\end{array}$ & $\mathrm{x}$ & & & $\mathrm{X}$ & & $\mathrm{x}$ & & & \\
\hline $\mathrm{T} 2-2$ & $\begin{array}{l}\text { Marble adjacent to mafic dike } \\
\text { sample T2-1 }\end{array}$ & $\mathrm{x}$ & & $\mathrm{X}$ & $\mathrm{X}$ & & $\mathrm{x}$ & & & \\
\hline
\end{tabular}

* Graphite identified in hand sample by streak, not in thin section. Graphite may or may not be the only opaque in a thin section. 


\section{Skarn}

Skarn is prevalent throughout the southwestern screen at quartzite-marble contacts and granitic rock-marble contacts (Figs. 32A and B). A granitic pegmatite-marble contact at station T3 has endoskarn within the pegmatite and exoskarn within the marble (Fig. 32A). Other skarn found in the southwestern screen includes epidote-bearing skarn at stations ML 53 and ML 54, and wollastonite-bearing skarn at station ML 51.

Sample T3-1 is a clinopyroxene-epidote endoskarn (T3-1a) within a granitic pegmatite (T3-1b) that outcrops $4 \mathrm{~m} \mathrm{NW}$ of marble located at station T3-2 (Fig. 32A). The pegmatite-marble contact is eroded but evidence for its presence is provided by the occurrence of skarn minerals in both samples T3-1 and T3-2. Sample T3-2 is clinopyroxene-marble with minor chondrodite and garnet (Table 8). 


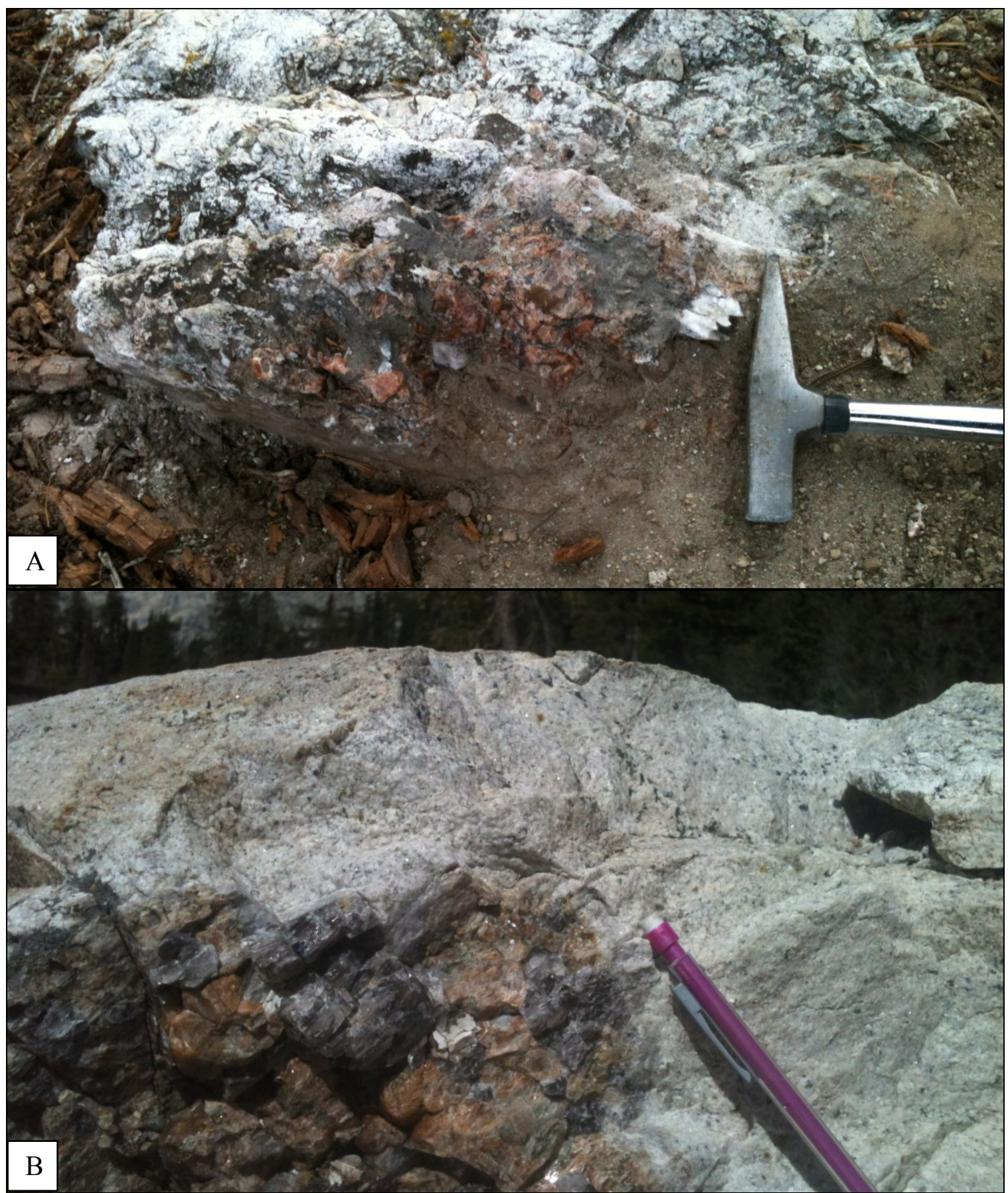

Figure 32. Skarn in the southwestern screen. A) Red garnet skarn in granitic pegmatite at station T3. Rock hammer for scale. B) Garnet-quartz skarn at contact between marble (below skarn, not visible in picture) and granitic rock of the TIS (above skarn, visible) at station ML 54. Pencil for scale. 
Table 8. Sample description and mineralogy of endoskarn sample T3-1 and marble sample T3-2.

\begin{tabular}{|c|c|c|c|c|c|c|c|c|c|c|c|c|}
\hline Sample & Description & Qtz & Cpx & Grt & Ep & Pl 1 & $\mathrm{Kfs}$ & $\mathrm{Cal}$ & Wo & Chn & $\mathrm{Brc}$ & opq \\
\hline T3-1a & $\begin{array}{l}\text { Skarn in quartz } \\
\text { monzonite pegmatite } \\
\text { near marble T3-2 }\end{array}$ & $\mathrm{x}$ & $\mathrm{x}$ & & $\mathrm{x}$ & $\mathrm{x}$ & $\mathrm{x}$ & & & & & \\
\hline T3-2 & $\begin{array}{l}\text { Chondrodite-bearing } \\
\text { marble nearest T3-1 }\end{array}$ & & $\mathrm{x}$ & $\mathrm{x}$ & & & & $\mathrm{x}$ & $\mathrm{x}$ & $\mathrm{x}$ & $\mathrm{x}$ & $\mathrm{x}$ \\
\hline
\end{tabular}

\section{Metamorphosed Mafic Dikes}

In the southwestern screen, fine-grained metamorphosed mafic dike sample T2-1 has clinopyroxene + plagioclase + quartz with a $\sim 1-2 \mathrm{~cm}$ thick boudinaged garnet-rich band of garnet + clinopyroxene + quartz. Sample T2-2, collected from marble adjacent the dike, consists of clinopyroxene + phlogopite + calcite + chondrodite (Table 9).

Table 9. Sample descriptions and mineral assemblages of samples T2-1 and T2-2.

\begin{tabular}{lllllllll}
\hline \hline Sample & Description & Qtz & Cpx & Grt & Pl & Phl & Cal & Chn \\
\hline T2-1 & $\begin{array}{l}\text { Fine-grained, vibrant green } \\
\text { metamorphosed mafic dike }\end{array}$ & x & x & x & x & & & \\
T2-2 & $\begin{array}{l}\text { Marble adjacent metamorphosed } \\
\text { mafic dike }\end{array}$ & & x & & & x & x & x \\
\hline
\end{tabular}




\section{WHOLE ROCK GEOCHEMISTRY AND PSEUDOSECTIONS}

Due to their generally homogenous, fine-grained textures and geographically dispersed sample locations, samples ML 1-5, ML 6-2, and ML 13.5-1 were selected for whole rock geochemical analysis and pseudosection modeling. Sample ML 1-5 was collected from near the north shore of May Lake approximately $40 \mathrm{~m}$ from the Mt. Hoffman granodiorite contact and a few meters from andalusite-corundum-muscovitebearing granitic pegmatites. ML 1-5 is rich in opaque minerals and aluminosilicate minerals. Sillimanite is present as euhedral blades and basal squares with diagonal cleavage. The bladed sillimanite appears to have altered to chlorite near fractures in the rock. Andalusite is anhedral and is commonly sericitized. Rutile and zircon appear as inclusions within cordierite.

Samples ML 6-2 and ML 13.5-1 originate from the center of the screen, approximately equidistant from contacts with the TIS or YVIS. Sample ML 6-2 is biotite-rich and contains an opaque mineral which EDS revealed to be magnetite. Sample ML 13.5-1, the southernmost sample selected for whole rock geochemistry, was collected from a metapelite-rich zone to the southwest of sample ML 6-2. Titanite is present in trace amounts within sample ML 13.5-1, and is abundant in the quartzite adjacent to this sample.

Samples ML 1-5, ML 6-2, and ML 13.5-1 were analyzed for whole rock geochemistry by X-ray fluorescence spectrometry (XRF) and Inductively Coupled Plasma Mass Spectrometry (ICP-MS) for major and trace elements, respectively. Mineral assemblages of these samples are provided in Petrography and Mineral 
Chemistry Section, Table 2 (page 39). Major element results of the geochemical analyses for the three metapelites are provided in Table 10.

Table 10. Major elements (in weight \% oxide) of May Lake metapelite samples.

\begin{tabular}{|c|c|c|c|}
\hline Oxide & ML 1-5 & ML 6-2 & ML 13.5-1 \\
\hline $\mathrm{SiO}_{2}$ & 48.39 & 75.83 & 52.84 \\
\hline $\mathrm{TiO}_{2}$ & 2.907 & 0.725 & 3.622 \\
\hline $\mathrm{Al}_{2} \mathrm{O}_{3}$ & 25.89 & 11.16 & 17.02 \\
\hline $\mathrm{FeO}^{*}$ & 9.31 & 5.37 & 13.52 \\
\hline $\mathrm{MnO}$ & 0.042 & 0.062 & 0.138 \\
\hline $\mathrm{MgO}$ & 1.90 & 2.04 & 2.69 \\
\hline $\mathrm{CaO}$ & 0.38 & 1.83 & 0.66 \\
\hline $\mathrm{Na}_{2} \mathrm{O}$ & 0.69 & 0.36 & 1.30 \\
\hline $\mathrm{K}_{2} \mathrm{O}$ & 8.06 & 1.58 & 6.22 \\
\hline $\mathrm{P}_{2} \mathrm{O}_{5}$ & 0.091 & 0.095 & 0.310 \\
\hline Sum & 97.65 & 99.06 & 98.33 \\
\hline LOI (\%) & 1.50 & 0.85 & 0.95 \\
\hline $\operatorname{Tr}$ (wt\% oxide) & 0.58 & 0.14 & 0.38 \\
\hline Sum w/LOI** & 99.72 & 100.05 & 99.66 \\
\hline With $\mathrm{Fe}^{3+\mathrm{t}}$ & 100.76 & 100.64 & 101.16 \\
\hline \multicolumn{4}{|c|}{$\begin{array}{l}\mathrm{LOI}=\text { loss on ignition } \\
\mathrm{Tr}=\text { trace } \\
\mathrm{Wt}=\text { weight } \\
\%=\text { percent } \\
{ }^{*} \mathrm{All} \text { Fe measured as FeO. } \\
{ }^{*} \text { Sum of Major elements (wt } \% \text { oxide) + Trace elements (wt } \% \text { oxide) }+\mathrm{LOI} \\
{ }^{\mathrm{t}} \text { Sum of Major elements (wt } \% \text { oxide) + Trace elements (wt } \% \text { oxide) }+\mathrm{LOI} \text { with } \mathrm{Fe}=\mathrm{Fe}^{3+} \text {. }\end{array}$} \\
\hline
\end{tabular}

The three metapelite samples have distinctly different chemical compositions. The northernmost sample, ML 1-5, is the most aluminous and potassic, least silicic, and has the highest loss on ignition (LOI) measured of the three pelites, suggesting it is the most volatile-rich of the three samples. Sample 13.5-1 is the most ferric and titanium-rich, and sample ML 6-2 is the most silicic. 


\section{Pseudosections}

In order to estimate the pressure-temperature conditions of metamorphism for metapelites within the May Lake IPS, isochemical P-T phase diagrams, termed “pseudosections," were produced using the Perple_X 6.7.6 program set (Connolly, 1990; 2009; Connolly and Petrini, 2002) as updated in February 2017, and using an internally consistent thermodynamic dataset by Holland and Powell (1998), revised in 2004. Pseudosection calculations were performed for the NCKFMASH $\left(\mathrm{Na}_{2} \mathrm{O}-\mathrm{CaO}-\mathrm{K}_{2} \mathrm{O}-\mathrm{FeO}-\right.$ $\mathrm{MgO}-\mathrm{Al}_{2} \mathrm{O}_{3}-\mathrm{SiO}_{2}-\mathrm{H}_{2} \mathrm{O}$ ) system, and the $\mathrm{P}-\mathrm{T}$ range of $0.5-5.5 \mathrm{kbars}$ and $300-800^{\circ} \mathrm{C}$.

The Perple_X program uses solid solution models to calculate fields of stability for mineral assemblages. Fields with higher variance are shown as darker shaded regions, and fields with low variance are shown as lighter regions; white fields represent divariance. For many minerals, several solution models are available that differ in how they model the thermodynamic behavior of solid-solution minerals based on specific chemistry or P-T conditions. Table 11 provides a comprehensive list of the mineral solution models chosen for the May Lake pseudosection calculations and a reference for each solution model. Solution models appropriate for the May Lake metapelites were chosen based on the solution model descriptions provided with the Perple_X program and successful use of the solution models in studies of metapelites with similar P-T conditions (e.g., Sengupta et al., 2009; Anenburg and Katzir, 2014; Mottram et al., 2014). Solution models for ilmenite, rutile, and magnetite were not included in the final pseudosections: these solution models were included in the pseudosection modeling iterative process, but based on comparison between pseudosections for the same sample 
with and without these solution models, it was determined that they did not significantly change the locations of the fields containing the dominant minerals in the samples (e.g. biotite, cordierite, plagioclase) and therefore did not provide beneficial additional information for interpretation of P-T conditions.

Table 11. Comprehensive list of solution models and references used for pseudosection calculation. Not all models were used for each pseudosection.

\begin{tabular}{lll}
\hline \hline Solution Model & Minerals & Reference \\
\hline Bio(TCC) & Biotite & Tajcmanová et al. (2009) \\
Gt(HP) & Garnet & Holland and Powell (1998) \\
hCrd & Cordierite & (ideal) Holland and Powell (1998) \\
melt(HP) & NCKFMASH melt & $\begin{array}{l}\text { Holland and Powell (2001); White et al. } \\
(2001)\end{array}$ \\
Mica(CHA) & white muscovite minerals & $\begin{array}{l}\text { Auzanneau et al. (2010); Coggon and Holland } \\
\text { (2002) }\end{array}$ \\
Pl(h) & Plagioclase feldspar & Newton et al. (1980) \\
San & Potassium feldspar & Waldbaum and Thompson (1968) \\
Kf & Potassium feldspar & Waldbaum and Thompson (1968) \\
Chl & Chlorite & Holland and Powell (1998) \\
Ctd(HP) & Chloritoid & White, Powell, Holland, and Worley (2000) \\
St(HP) & Staurolite & Parameters from THERMOCALC \\
Opx(HP) & Orthopyroxene & Holland and Powell (1996)
\end{tabular}

Weight percent (\%) $\mathrm{H}_{2} \mathrm{O}$ for each sample was estimated from XRF loss on ignition (LOI) results. Isobaric temperature- $\mathrm{H}_{2} \mathrm{O}$ weight percent $\left(\mathrm{T}-\mathrm{X}_{\mathrm{H} 2 \mathrm{O}}\right)$ pseudosections with $\mathrm{H}_{2} \mathrm{O}$ varying from 0 to 2.5 weight $\%$ were created to assess whether major changes to mineral assemblages occurred within the expected temperature range $\left(\sim 500-700^{\circ} \mathrm{C}\right)$ as weight $\% \mathrm{H}_{2} \mathrm{O}$ varied. Based on the consistency of mineral assemblage fields with change in weight $\% \mathrm{H}_{2} \mathrm{O}$ in the $\mathrm{T}-\mathrm{X}_{\mathrm{H} 2 \mathrm{O}}$ pseudosections, it was determined that the LOI 
values were reasonable estimates for weight $\% \mathrm{H}_{2} \mathrm{O} . \mathrm{H}_{2} \mathrm{O}$ was set as a thermodynamic component of the calculations, and all pseudosections were generated assuming $\mathrm{SiO}_{2}$ saturation due to the presence of quartz. The pseudosection for sample ML 1-5 was generated also assuming saturation in $\mathrm{Al}_{2} \mathrm{O}_{3}$ due to the presence of aluminosilicate minerals in the assemblage and the high $\mathrm{Al}_{2} \mathrm{O}_{3}$ weight percent of the sample. Labels for less important fields are omitted in the pseudosections discussed below.

\section{1-5}

The pseudosection generated for metapelite sample ML 1-5 is provided as Figure 33. Minerals observed in sample ML 1-5 were quartz + biotite + cordierite + andalusite + white mica + sillimanite + chlorite + rutile + zircon + opaque minerals. It should be noted that this mineral assemblage does not appear to be in equilibrium based on the coexistence of anhedral andalusite (partially altered to sericite) with euhedral sillimanite. Additionally, due to the fine-grained nature of the rock, not all minerals were positively identified using optical properties and microprobe data were not available to aid in mineral identification. Due to these limitations, the actual mineral assemblage of ML 1-5 could not be compared to the pseudosection modeled regions to definitively predict P-T conditions of metamorphism. Regions of the pseudosection containing quartz, cordierite, biotite, and plagioclase and lacking garnet are outlined in red on Figure 33 to indicate potential pressure-temperature ranges of metamorphism: $<3.7 \mathrm{kbars}$ and $500-700^{\circ} \mathrm{C}$. 


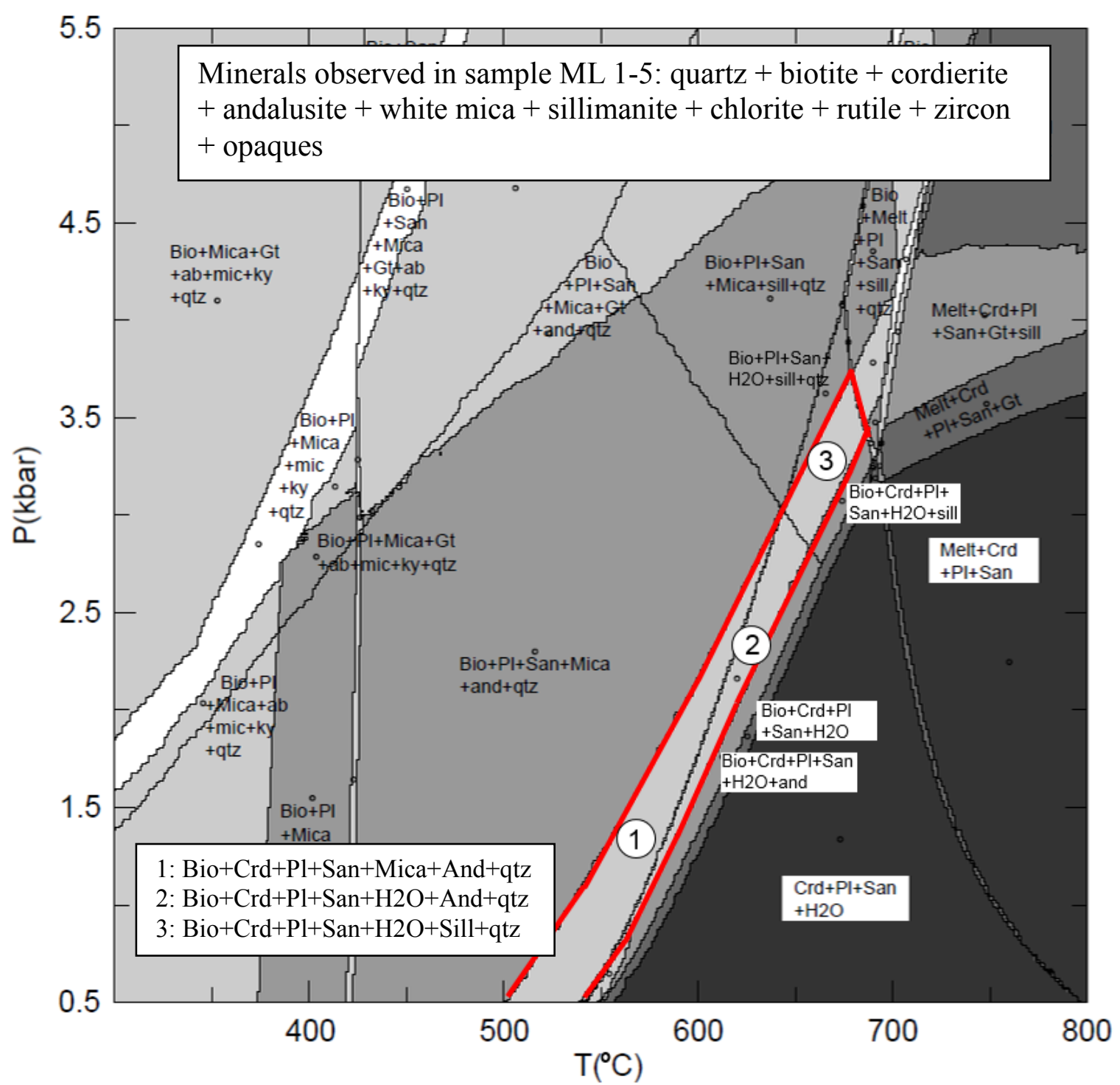

Figure 33. Pseudosection diagram of ML 1-5. Regions outlined in red represent potential mineral assemblages.

The highlighted regions include the assemblage: quartz + biotite + cordierite + plagioclase + K-feldspar $($ san $) \pm$ white muscovite (Mica) \pm andalusite or sillimanite \pm $\mathrm{H}_{2} \mathrm{O}$. 


\section{6-2}

The pseudosection generated for metapelite sample ML 6-2 is provided as Figure 34. Minerals observed in sample ML 6-2 were quartz + biotite + cordierite + plagioclase + zircon + magnetite. Magnetite was positively identified during electron microprobe analysis. Ilmenite and other opaque minerals may also be present, but were not confirmed. Additionally, due to the fine-grained nature of the rock, not all minerals were positively identified using optical properties. Due to these limitations, the actual mineral assemblage of ML 6-2 could not be compared to the pseudosection modeled regions to definitively predict P-T conditions of metamorphism. Regions of the pseudosection containing cordierite, biotite, plagioclase, and quartz and lacking garnet, mica, staurolite, sillimanite, and orthopyroxene are outlined in red on Figure 34 as the potential pressuretemperature ranges of metamorphism of this rock: $<4.3$ kbars and $533-725^{\circ} \mathrm{C}$. The highlighted regions include the assemblage: quartz + biotite + cordierite + plagioclase + K-feldspar ( san) $\pm \mathrm{H}_{2} \mathrm{O}$. 


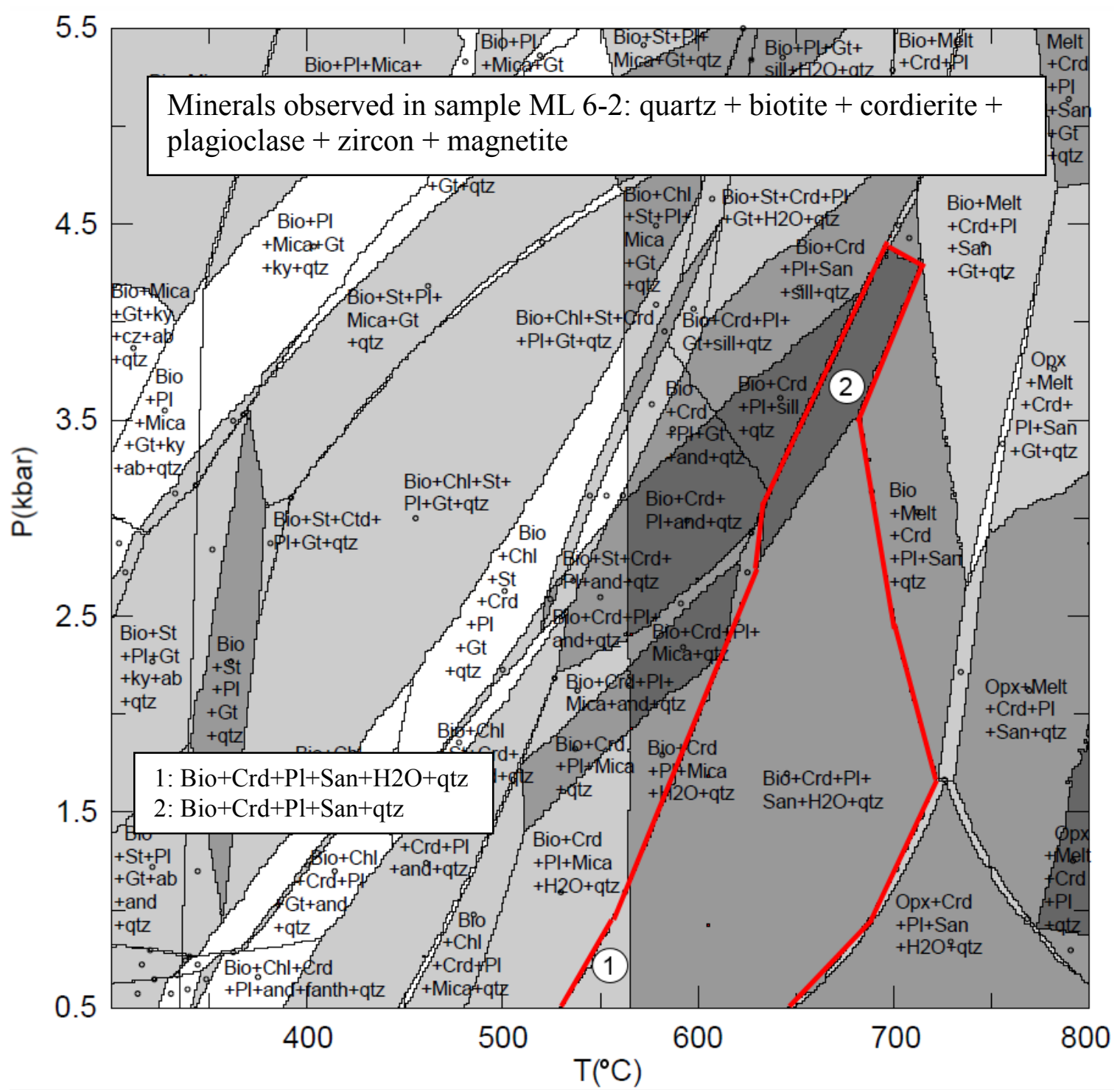

Figure 34. Pseudosection diagram of metapelite sample ML 6-2. Regions outlined in red represent potential mineral assemblages.

\section{13.5-1}

The pseudosection generated for metapelite sample ML 13.5-1 is provided as Figure 35. Minerals observed in sample ML 13.5-1 include quartz + biotite + cordierite + plagioclase $+\mathrm{K}$-feldspar + zircon + rutile + titanite + opaques. Opaque minerals were 


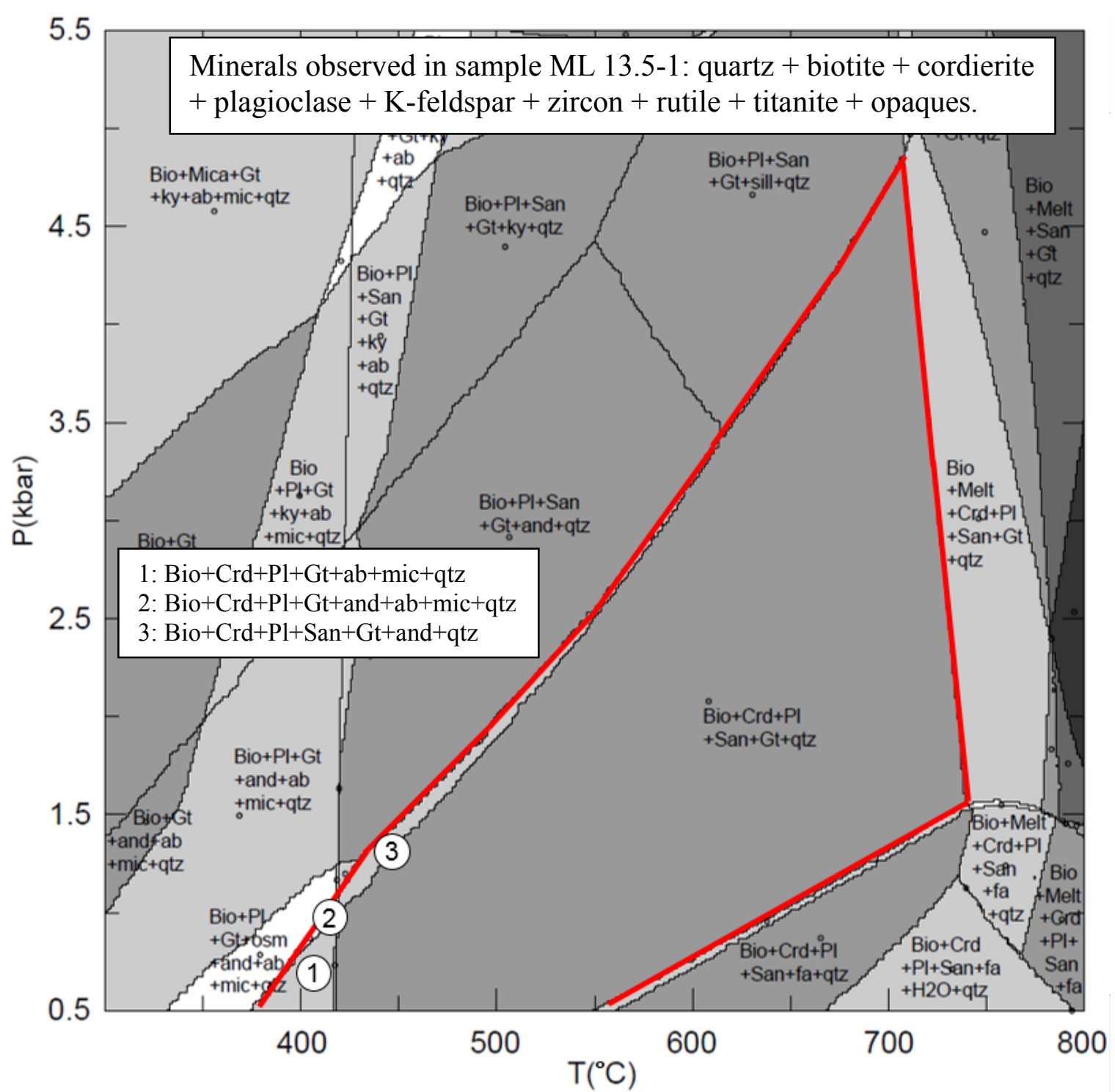

Figure 35. Pseudosection diagram of metapelite sample ML 13.5-1. Regions outlined in red represent potential mineral assemblages.

not identified. It should be noted that garnet is ubiquitous throughout the pseudosection but was not identified in thin section in sample ML 13.5-1. However, as the samples selected for pseudosection analysis were selected specifically for their very fine-grain size, limiting the identification of minerals based solely on their optical properties, it is 
possible that garnet and other minerals are present. Due to these limitations, the actual mineral assemblage of ML 13.5-1 could not be compared to those modeled in the pseudosection. Regions of the pseudosection containing cordierite, biotite, plagioclase, quartz, and K-feldspar (in addition to garnet) and lacking mica and orthopyroxene are outlined in red on Figure 35 as the potential pressure-temperature ranges of metamorphism of this rock: $<4.8 \mathrm{kbars}$ and $<737^{\circ} \mathrm{C}$. The highlighted regions include the assemblage: quartz + biotite + cordierite + plagioclase $(\mathrm{pl}$ or ab) $+\mathrm{K}$-feldspar (san or mic) + garnet \pm andalusite 


\section{CALCITE STABLE ISOTOPE RESULTS}

The $\delta^{18} \mathrm{O}_{\mathrm{VSMOW}}$ and $\delta^{13} \mathrm{C}_{\mathrm{PDB}}$ of calcite aliquots from three marble samples, two calcsilicate hornfels samples, and one skarn sample from the northeastern screen (Fig. 36) and twelve marble samples from the southwestern screen (Fig. 37) are provided in Table 12.

\section{Stable Isotope Results from the Northeastern Screen}

Marble samples from the northeastern screen show $\delta^{18}$ Ovsmow values of 8.90 to $17.27 \%$ and $\delta^{13} \mathrm{C}_{\mathrm{PDB}}$ values of -5.00 to $0.80 \%$. The lowest $\delta^{18} \mathrm{O}_{\text {vSmOw }}$ and $\delta^{13} \mathrm{C}_{\mathrm{PDB}}$ values are seen in the northernmost marble sample, ML 2-5, which is from marble thinly interlayered with calc-silicate rock and enclosed by the dominant lithology of metapelite and quartzite. Marble samples ML 23-2 and ML 46-1 are from pods of continuous marble $1 \mathrm{~m}$ and $5 \mathrm{~m}$ in diameter, respectively.

The two calc-silicate samples analyzed from the northeastern screen, samples ML 171 and ML 21-2, vary largely in $\delta^{18} \mathrm{OVSM}_{\mathrm{V} M \mathrm{w}}$ and moderately in $\delta^{13} \mathrm{C}_{\mathrm{PDB}}$ (Table 12). ML 21-2, located in the farthest northeast section of the screen, has much higher $\delta^{18} \mathrm{O}_{\mathrm{VSMOW}}$ and somewhat lower $\delta^{13} \mathrm{C}_{\mathrm{PDB}}$ than ML 17-1. 


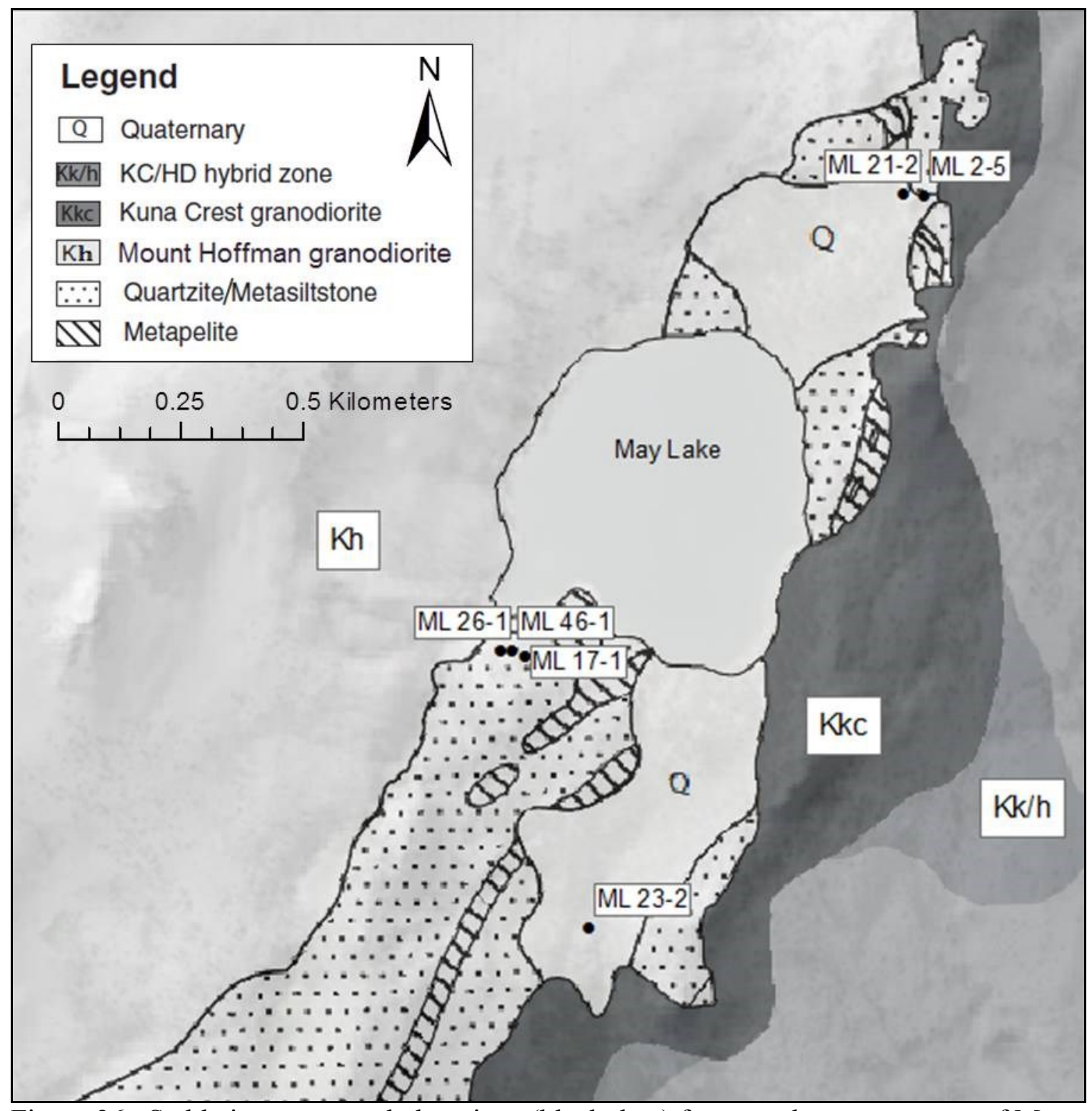

Figure 36. Stable isotope sample locations (black dots) from northeastern screen of May Lake IPS. Basemap edited from Memeti et al. (2010). 


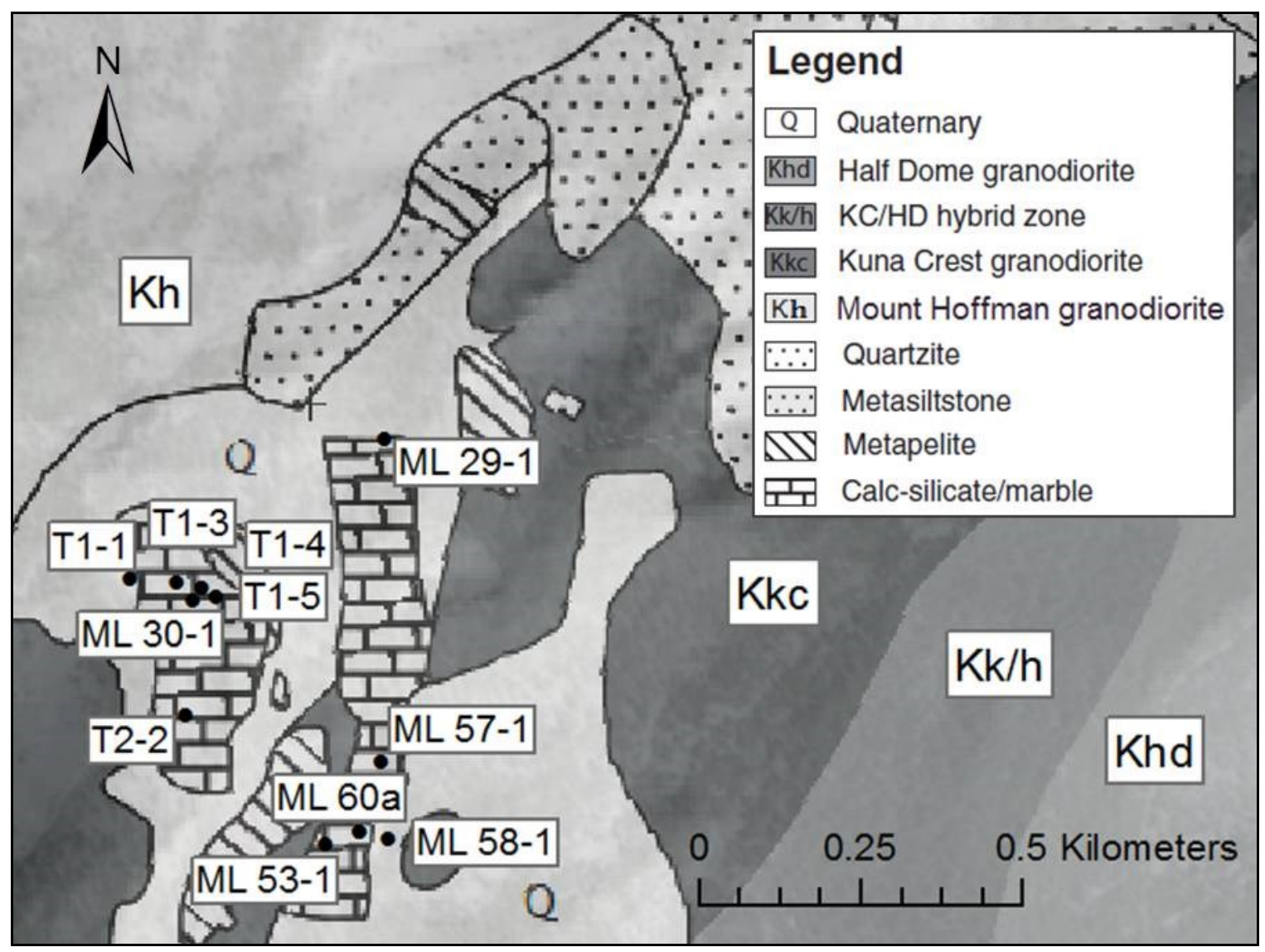

Figure 37. Stable isotope sample locations (black dots) from southwestern screen of May Lake IPS. Basemap edited from Memeti et al. (2010). 
Table 12. Calcite $\delta^{18} \mathrm{OV}_{\text {vsmow } \% \text {, }} \delta^{13} \mathrm{C}_{\mathrm{PDB}} \%$, and analytical error values of May Lake IPS samples.

\begin{tabular}{|c|c|c|c|c|c|c|c|c|}
\hline Location & Sample ID & Rock type & $\delta^{18}$ OvsMow & $\pm 1 \sigma$ & $\pm 2 \sigma$ & $\delta^{13} \mathrm{C}_{\mathrm{PDB}}$ & $\pm 1 \sigma$ & $\pm 2 \sigma$ \\
\hline \multirow{7}{*}{$\begin{array}{l}\text { Northeastern } \\
\text { Screen }\end{array}$} & ML 2-5 & marble & 8.90 & 0.05 & \multirow{7}{*}{0.41} & -5.00 & 0.03 & \multirow{7}{*}{0.33} \\
\hline & ML 21-2 & calc-silicate & 12.94 & 0.05 & & -4.06 & 0.07 & \\
\hline & ML 17-1* & calc-silicate & 9.05 & & & -3.10 & & \\
\hline & ML 26-1a & skarn & 9.12 & 0.05 & & -1.92 & 0.06 & \\
\hline & ML 26-1b & skarn & 15.80 & 0.05 & & -0.89 & 0.05 & \\
\hline & ML 23-2 & marble & 17.27 & 0.06 & & -1.19 & 0.05 & \\
\hline & ML 46-1 & marble & 16.46 & 0.07 & & 0.80 & 0.03 & \\
\hline \multirow{13}{*}{$\begin{array}{l}\text { Southwestern } \\
\text { Screen }\end{array}$} & ML 29-1 & marble & 19.23 & 0.04 & & 0.55 & 0.07 & \\
\hline & ML 30-1 & marble & 19.52 & 0.05 & & 1.18 & 0.09 & \\
\hline & $\mathrm{T} 1-1 \mathrm{a}$ & marble & 20.83 & 0.07 & & 1.86 & 0.08 & \\
\hline & $\mathrm{T} 1-1 \mathrm{~b}$ & marble & 20.74 & 0.08 & & 1.72 & 0.10 & \\
\hline & $\mathrm{T} 1-3$ & marble & 20.58 & 0.07 & & 1.07 & 0.04 & \\
\hline & $\mathrm{T} 1-4$ & marble & 20.41 & 0.03 & & 1.30 & 0.08 & \\
\hline & $\mathrm{T} 1-5$ & marble & 22.25 & 0.04 & & 1.15 & 0.07 & \\
\hline & $\mathrm{T} 2-2$ & marble & 12.64 & 0.02 & & 0.14 & 0.03 & \\
\hline & ML 53-1 & marble & 20.18 & 0.10 & & 0.98 & 0.06 & \\
\hline & ML 57-1 & marble & 20.21 & 0.04 & & 1.01 & 0.07 & \\
\hline & ML 58-1 & marble & 19.56 & 0.06 & & 1.40 & 0.05 & \\
\hline & ML 60a-1 & marble & 19.41 & 0.07 & & 0.69 & 0.04 & \\
\hline & ML 60a-3 & marble & 19.66 & 0.07 & & 0.59 & 0.09 & \\
\hline
\end{tabular}

*External precision $(1 \sigma)$ is $\leq 0.1 \%$ o for all samples except calc-silicate hornfels sample ML 17-1 for which a low total signal was received and analytical error is increased to $2 \sigma$.

Strong variation in $\delta^{18} \mathrm{O}_{\text {vSmow }}$ between two aliquots of a single sample is observed in the calcite aliquots ML 26-1a and 26-1b from sample ML 26-1, a thin, finely zoned vein or metamorphic skarn (Table 12, Fig. 38). Both aliquots were selected from the coarsegrained calcite zone (Fig. 38, top of rock). However, aliquot ML 26-1a was obtained by 
cutting parallel to the calcite vein surface and separating single calcite grains from the cutting to be powdered and analyzed. Aliquot ML 26-1b was collected by cutting perpendicular to the calcite-covered surface, and selecting calcite grains that were closer to the calc-silicate rock and associated with 1-3\% fine-grained diopside.

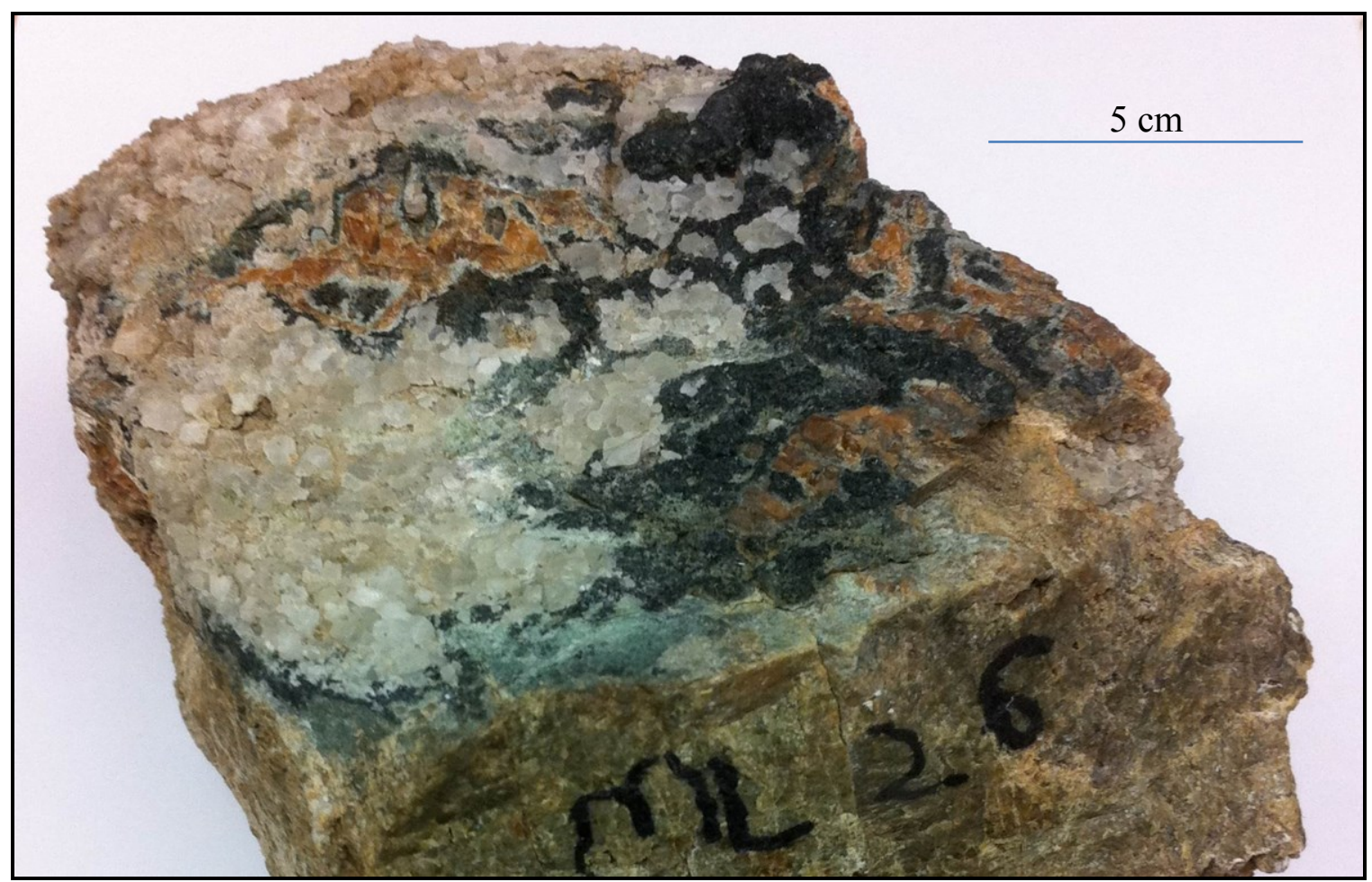

Figure 38. Hand sample ML 26-1. Coarse-grained white calcite, fine-grained dark green diopside, and fine-grained reddish orange garnet skarn on surface of fine-grained green calc-silicate hornfels. Analyzed calcite aliquots ML 26-1a and ML 26-1b were selected from coarse-grained calcite zone.

\section{Stable Isotope Results from the Southwestern Screen}

With one exception, marble samples from the southwestern screen have consistent calcite stable isotopic signatures: $\delta^{18} \mathrm{O}_{\mathrm{VSMOW}}$ from 19.23 to $22.25 \%$ and $\delta^{13} \mathrm{C}_{\mathrm{PDB}}$ from 0.55 to $1.86 \%$ (Table 12 ). The exception, sample T2-2, has much lower values of 
$\delta^{18} \mathrm{O}_{\text {vsmow }}$ of $12.64 \pm 0.02 \%$ and $\delta^{13} \mathrm{C}_{\mathrm{PDB}}$ of $0.14 \pm 0.03 \%$. This sample was collected less than $1 \mathrm{~m}$ from a large (>1 m thick) metamorphosed mafic dike (Fig. 39).

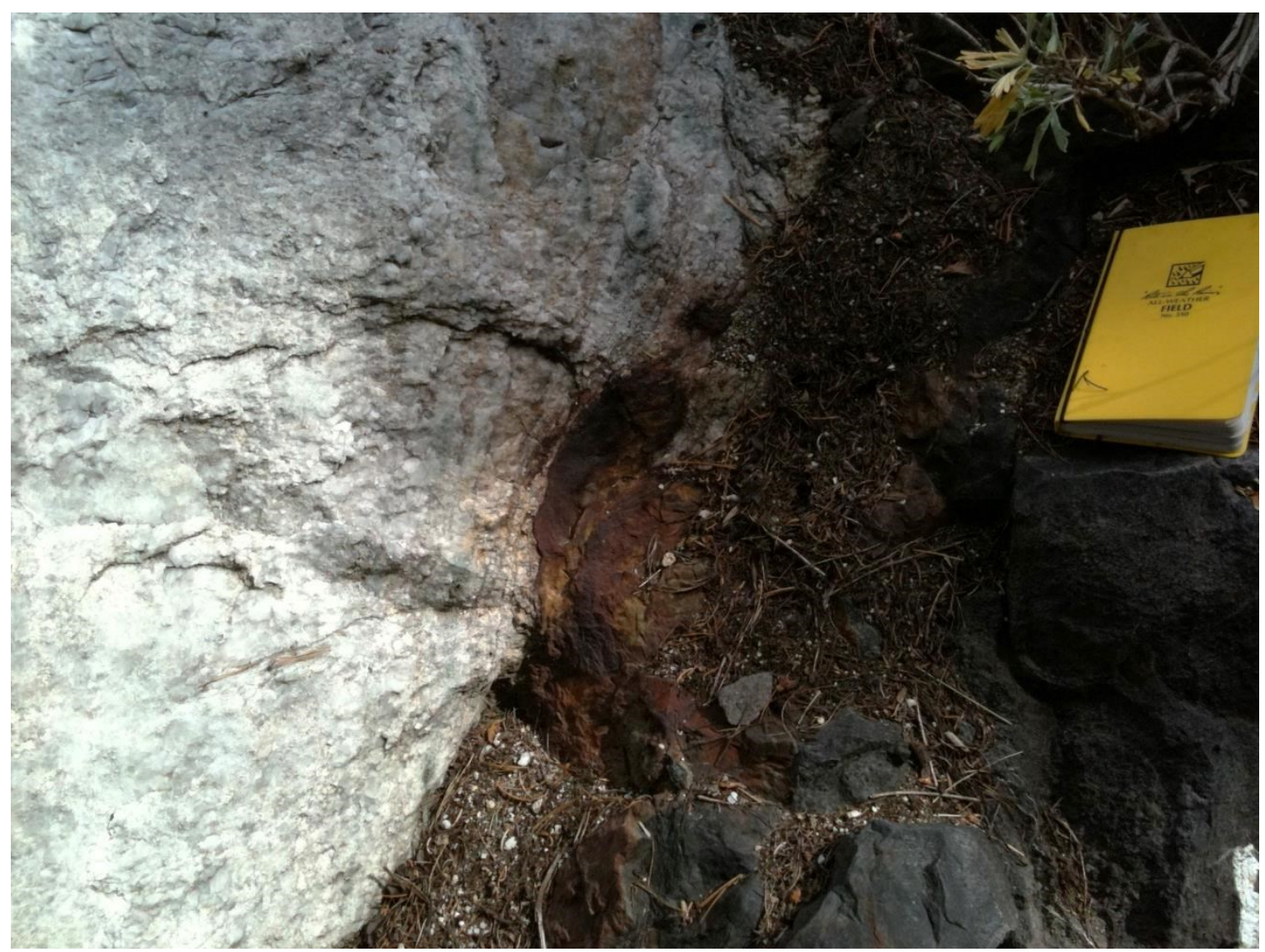

Figure 39. Field photograph of sample T2-2 marble and sample T2-1 thick metamorphosed mafic dike. 18-cm long field notebook provided for scale.

In contrast, two samples collected from varying distances away from a dike at station ML 60a have minimal difference in stable isotope analytical results. Sample ML 60a-1 was taken from within $10 \mathrm{~cm}$ of a 4-cm-wide mafic dike outcropping for $\sim 28 \mathrm{~m}$ in length. Sample ML 60a-3 was selected from the same sample station, but $2 \mathrm{~m}$ away from the 
dike (Fig. 40). Results show no analytical difference in $\delta^{13} \mathrm{C}$ values and less than $0.2 \%$ o difference in $\delta^{18} \mathrm{O}$.

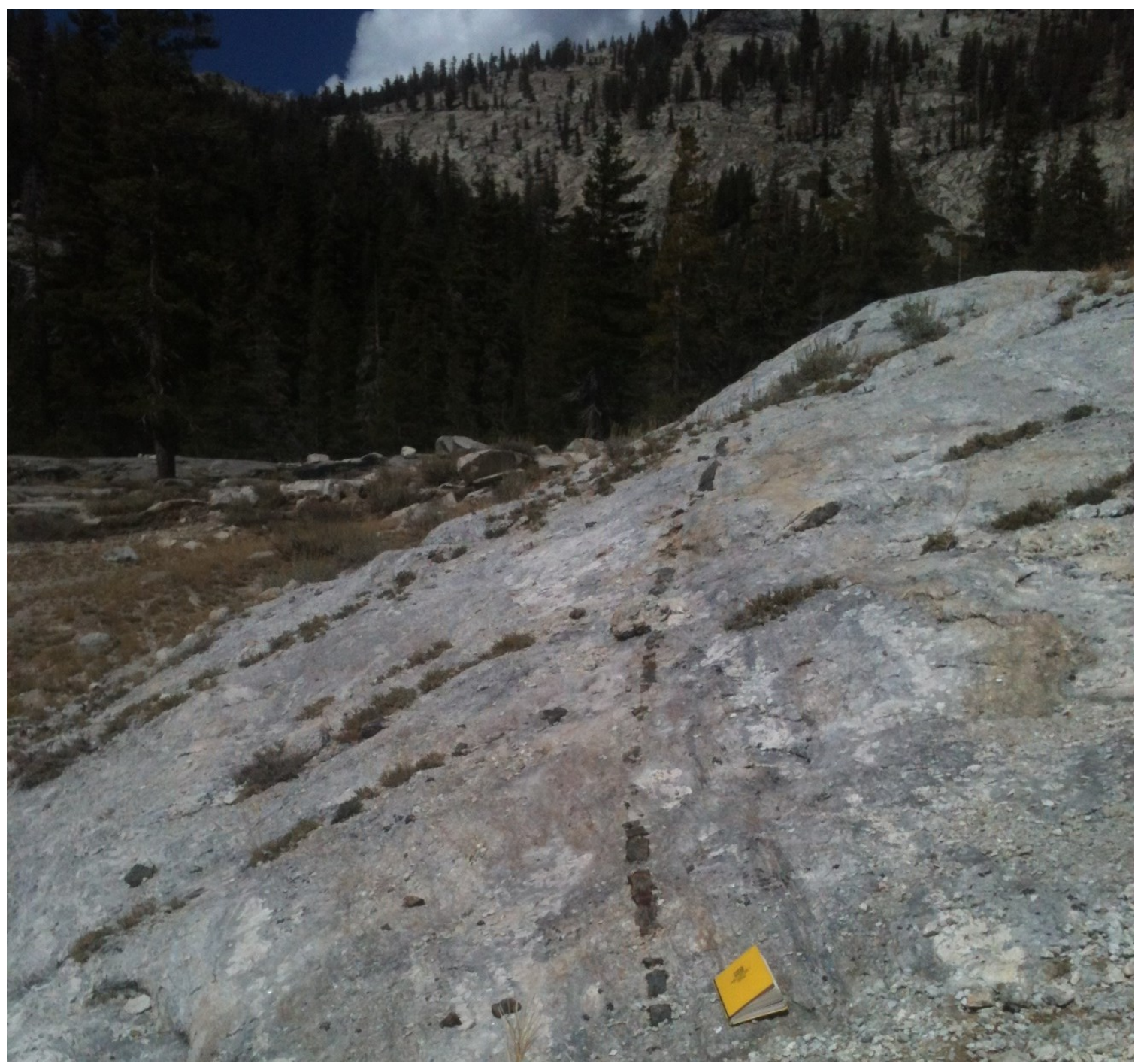

Figure 40. $4 \mathrm{~cm}$ thick dike extending through marble at station ML 60a for $\sim 28 \mathrm{~m}$. Sample ML 60a-1 was selected from within $10 \mathrm{~cm}$ of dike. Sample ML 60a-3 was collected from $\sim 2 \mathrm{~m}$ away from the dike. $18 \mathrm{~cm}$ field notebook for scale. 


\section{DISCUSSION}

\section{Conditions of Metamorphism}

\section{Presence of Sillimanite}

Sillimanite is present in metapelites from stations ML 1 and ML 3 in the northeastern section of the screen but was not identified in samples collected elsewhere in the May Lake IPS. The samples containing sillimanite were collected approximately 40 to $100 \mathrm{~m}$ from the nearest outcrop of Mount Hoffman Granodiorite and near numerous granitic pegmatite intrusions that were suggested by Rose (1957b) to have originated from the younger TIS. The coexistence of anhedral andalusite (partially altered to sericite) with euhedral sillimanite in sample ML 1-5 suggests that metapelites exposed in the northeastern portion of the screen were affected by a later, higher-temperature metamorphic event.

Sillimanite has also been reported from the Benson Lake pendant located $\sim 18 \mathrm{~km}$ to the north of May Lake (Memeti et al., 2012), in a $\sim 1.5 \mathrm{~km}$-long pendant at McGee Lake $\sim 7.5 \mathrm{~km}$ to the northeast of May Lake (Van Dyne, 2014), and from a metasedimentary body at Coyote Rocks $\sim 5 \mathrm{~km}$ to the southwest of May Lake (Petsche, 2008). The pendants at Benson Lake and McGee Lake lie along the contact between plutons of the YVIS and the TIS, while the metasedimentary body at Coyote Rocks is surrounded by the TIS. Sillimanite is absent in metasedimentary bodies to the northwest of May Lake within the El Capitan Granite of the YVIS and the $\sim 97$ Ma Yosemite Creek Granodiorite; andalusite was found in this area (Johnson, 2013). These observations suggest that the andalusite-bearing assemblage formed during contact metamorphism from the YVIS, 
whereas sillimanite formed during a second stage of higher-temperature contact metamorphism associated with emplacement of the TIS. The intrusion of the TIS tonalite/granodiorite may have caused higher temperature metamorphism than the YVIS granodiorite because of the relatively more mafic chemical composition of the TIS magma.

\section{Titanium in Biotite Thermometry}

Titanium concentrations in biotite from metapelite sample ML 6-2 (Table B-2) were averaged and used for assessment of titanium in biotite thermometry based on Henry et al. (2005). This thermometer requires the following assumptions for metapelites:

- $\mathrm{X}_{\mathrm{Mg}}=0.275$ to 1.0

- $\mathrm{Ti}=0.04-0.6$ atoms per formula unit

- $\mathrm{T}=480-800^{\circ} \mathrm{C}$

- Ilmenite or rutile present

- Graphite present to restrict $\mathrm{Fe}^{3+}$ to $\sim 12 \% \mathrm{Fe}^{\text {total }}$

- Quartz present

- Aluminous minerals such as cordierite, staurolite, and aluminosilicate polymorphs present

- Pressure $=4-6 \mathrm{kbar}$

The above assumptions are valid for metapelite ML 6-2 with the following exceptions: graphite was not identified in the sample, and the pressure of metamorphism is probably lower than 4 kbars based on estimated pressures for the Glen Aulin granodiorite near the May Lake IPS of 2.5-3 kbars (Webber et al., 2001; Valbone Memeti, email 
communication, April 20,2011). The thermometry calculation resulted in estimated temperatures of $683-714^{\circ} \mathrm{C}$ for metapelite sample ML 6-2, which is within the range of temperatures provided by the pseudosection modeling. However, because the estimated pressure of metamorphism for the May Lake IPS is below the pressure range assumed for the titanium in biotite thermometer, the calculated temperature range is likely biased high.

\section{Mg/Fe Ratios in Calc-Silicate Hornfels Clinopyroxenes}

$\mathrm{Mg} / \mathrm{Fe}$ ratios for clinopyroxene in calc-silicate hornfels vary with location within the May Lake IPS. Clinopyroxenes in samples ML 19 (southwestern end of May Lake) and ML 21 (northeast of May Lake) are richer in Mg than are those in samples from central stations ML 23 and ML 25 (Petrography and Mineral Chemistry section Fig. 19, page 43; Table B-3). This suggests that a higher temperature of metamorphism was experienced in the northern section of the northeastern screen than in the central section of the screen based on the relative sizes of $\mathrm{Mg}$ versus $\mathrm{Fe}$ and the energy required to accept the atoms into the mineral structure. This is consistent with the presence of sillimanite in metapelites exposed in the northern section of the northeastern screen. The cause of the relatively higher temperatures of metamorphism in this area of the screen versus farther south is not clear, but may be due to preferential pathways such as dikes and folds providing conduits for hot fluid from the plutons.

\section{Mineral Chemistry Zoning in 3-cm Garnet at ML 28}

Distinct chemical zoning in a 3-cm garnet from megaskarn station ML 28, with oscillation in $\mathrm{Al}$ and $\mathrm{Fe}$ content between zones, suggests that metasomatic fluid involved 
in the formation of garnet-bearing skarn changed over time. This may reflect the evolution of the fluid being released from the TIS as minerals crystallized in the magma over time, removing chemical components from the fluid. Periodic replenishment by fresh magma may explain the oscillatory nature of the garnet chemical zones. Mafic minerals crystallizing in the TIS magma lowered the Fe content and increased the relative Al content until fresh pulses of magma replenished the Fe to the system, allowing for more mafic minerals to crystallize again and repeat the cycle.

\section{Whole Rock Geochemistry and Pseudosections}

Based on pseudosections calculated for three metapelite samples, metamorphic temperatures ranged from $500-740^{\circ} \mathrm{C}$, at pressures $<4.8 \mathrm{kbars}$. Assuming a minimum pressure of 2.5 kbars (Webber et al., 2001; Valbone Memeti, email communication, April 20, 2011), the minimum estimated temperatures from the pseudosections are as follows:

ML 1-5: $\sim 617^{\circ} \mathrm{C}$;

ML 6-2: $\sim 610^{\circ} \mathrm{C}$; and

ML 13.5-1: $\sim 540^{\circ} \mathrm{C}$.

These results are consistent with the conclusion that the highest temperatures of metamorphism were recorded in rocks of northeastern screen, as discussed above. Additionally, the minimum temperature estimated for sample ML 13.5-1 is consistent with Rose's (1957a) temperature estimate of $540^{\circ} \mathrm{C}$ based on microcline mineral chemistry.

It should be noted that the usability of these pseudosection results is limited by uncertainties concerning the actual mineral assemblages present in the metapelite samples 
analyzed. X-ray diffraction and/or additional electron microprobe analysis would help to confirm the mineralogy of these fine-grained metapelite samples and thus permit refinement of P-T estimates based on the calculated pseudosections.

\section{Stable Isotope Geochemistry}

Stable isotope results were compared to literature values for the protolith carbonate rock type and the adjacent TIS and YVIS granitic bodies to assess the extent of isotopic alteration due to contact metamorphism. Previous detrital zircon provenance analyses suggest rocks of the May Lake IPS correlate with Ordovician units of central Nevada (Memeti, et al., 2010). $\delta^{18} \mathrm{O}_{\text {VSMOW }}$ and $\delta^{13} \mathrm{C}_{\mathrm{PDB}}$ values of Ordovician marine carbonates are approximately 19 to $28 \%$ and -2 to $+3 \%$, respectively (Bindeman, 2008; Faure and Mensing, 2005). Whole rock $\delta^{18}$ Ovsmow values for Glen Aulin tonalite of the TIS and El Capitan granite of the YVIS range from 7.05 to $7.74 \%$ and 8.15 to $9.02 \%$, respectively (Lackey et al., 2008). $\delta^{13} \mathrm{C}_{\mathrm{PDB}}$ values of granitic rocks used for comparison are based on typical values for granitic rock: approximately $-5.5 \%$ (Bindeman, 2008).

\section{Northeastern Screen}

Marble samples from the northeastern screen (ML 2-5, ML 23-1, and ML 46-1) are isotopically depleted in $\delta^{18} \mathrm{O}$ relative to the Ordovician carbonate; these samples have $\delta^{18} \mathrm{O}_{\text {VSMOw }}$ results of $8.90 \pm 0.05 \%, 17.27 \pm 0.06 \%$, and $16.46 \pm 0.07 \%$, respectively. Relative depletion of both $\delta^{18} \mathrm{O}$ and $\delta^{13} \mathrm{C}$ increases to the northeast (Fig. 41). The most alteration from expected $\delta^{18} \mathrm{O}_{\text {VSMOW }}$ and $\delta^{13} \mathrm{C}_{\text {PDB }}$ values is seen in the northernmost marble sample, ML 2-5, which is from an approximately 4-m-wide outcrop of thin marble beds interlayered with calc-silicate rock and enclosed by the dominant lithology 


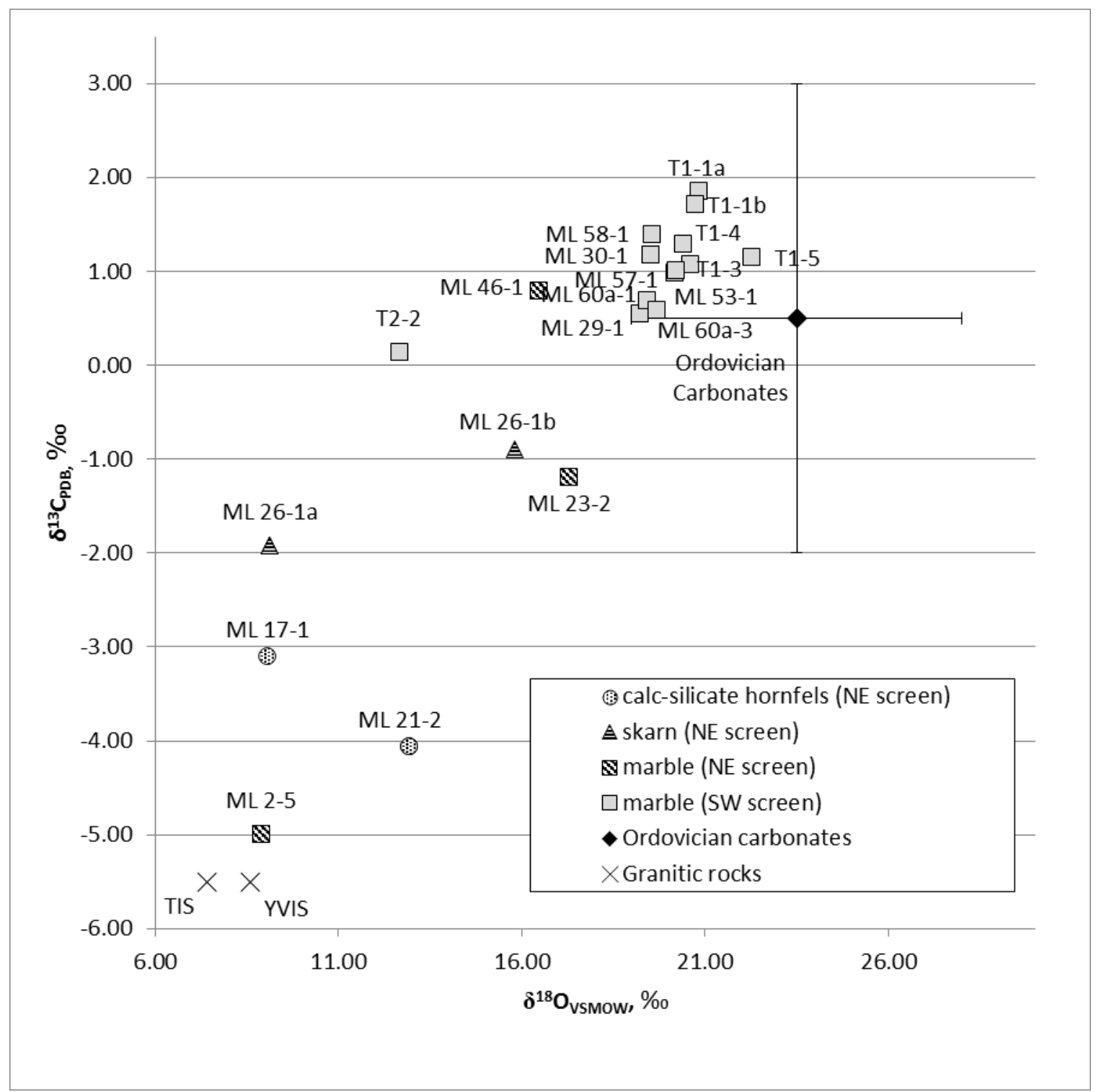

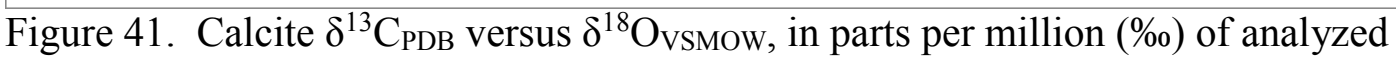
samples from the May Lake IPS. Approximate $\delta^{13} \mathrm{C}_{\text {PDB }}$ and $\delta^{18} \mathrm{O}_{\text {VSMOw }}$ values for adjacent granitic rocks (Bindeman, 2008; Lackey, et al., 2008) and Ordovician carbonates (Bindeman, 2008; Faure and Mensing, 2005) provided for comparison. TIS = Glen Aulin tonalite of the Tuolumne Intrusive Suite; YVIS = El Capitan granodiorite of the Yosemite Valley Intrusive Suite. 
of metapelite and quartzite. ML 2-5 was collected within a few tens of meters of the contact with the Glen Aulin granodiorite and within $100 \mathrm{~m}$ of the contact with the Mount Hoffman granodiorite. Samples ML 23-2 and ML 46-1 are from thicker marble bodies: 1 $\mathrm{m}$ and $5 \mathrm{~m}$ in visible diameter, respectively.

The cause of the difference in isotope values of calcites within single skarn sample ML 26 is unclear. Sample aliquot ML 26-1a was taken from the "pure" coarse calcite section of the sample while aliquot ML 26-1b was taken from the calcite-diopside zone closer to the non-skarn, calc-silicate rock side of the exoskarn. Therefore, the lower $\delta^{18} \mathrm{O}$ and $\delta^{13} \mathrm{C}$ values of ML 26-1a may be due to more complete equilibrium with granitic fluid. It should be noted that the measured $\delta^{18} \mathrm{O}_{\mathrm{VSMOW}}$ of samples ML 2-5, 17-1, and ML 26-1a, and the $\delta^{13} \mathrm{C}_{\mathrm{PDB}}$ of sample ML 2-5, are generally consistent with equilibration with fluid from the YVIS (8.90-9.12\%o $\delta^{18} \mathrm{OV}_{\text {VSMOw }}$ and $\left.-5.0 \%{ }^{13} \mathrm{C}_{\mathrm{PDB}}\right)$. However, this does not exclude the possibility of the samples interacting with fluid from the TIS as well.

The $\delta^{13} \mathrm{C}$ results of samples ML 2-5, ML 21-2, and ML 17-1 are below the expected $\delta^{13} \mathrm{C}_{\mathrm{PDB}}$ range of -2 to $+3 \%$ for Ordovician marine carbonates. The other samples were within the unshifted $\delta^{13} \mathrm{C}$ range.

No distinct relationship can be inferred as to isotopic variability with distance from contacts with either pluton. This may be due to the screen's relatively small size as well as only minor presence of calcite-bearing rocks to analyze in order to create a more complete map of isotope values for the area. Additionally, this observation suggests that local heterogeneity and structural anisotropies such as metamorphosed mafic dikes were the dominant factor for isotopic exchange with an external fluid. 


\section{Southwestern Screen}

Marble samples from the uniform, dominantly marble southwestern screen show less isotopic depletion and variation than those of the northeastern screen: 12 of the 13 marble samples from the southwestern screen had reported concentrations of $\delta^{18}$ Ovsmow and $\delta^{13} \mathrm{CPDB}_{\mathrm{PD}}$ within the Ordovician marine carbonate range. These relatively unshifted $\delta^{18} \mathrm{O}$ and $\delta^{13} \mathrm{C}$ values for the marbles are consistent with trends reported by Nabelek and Morgan (2011) for marbles, and indicate that the marbles did not equilibrate significantly with an external fluid. $\delta^{18} \mathrm{O}$ depletion is observed in marble sample T2-2 $(12.64 \pm 0.02 \%$ $\delta^{18} \mathrm{O}_{\text {VSMOW }}$ and $0.14 \pm 0.03 \% \delta^{13} \mathrm{C}_{\mathrm{PDB}}$ ), which suggests that structural anisotropies such as the nearby relatively thick $(>1 \mathrm{~m})$ amphibolite dike allowed more depletion in $\delta^{18} \mathrm{O}$ and $\delta^{13} \mathrm{C}$. The size of the dike effects the extent of isotopic depletion: samples ML 60a-1 and ML 60a-3, collected a few cm away and $1 \mathrm{~m}$ away, respectively, from a 4-cm-thick amphibolite dike, were within the range of unshifted $\delta^{18} \mathrm{O}$ and $\delta^{13} \mathrm{C}$ Ordovician marine carbonate values. 


\section{CONCLUSIONS}

- $\mathrm{Mg} / \mathrm{Fe}$ ratios of clinopyroxene in calc-silicate rocks and the presence of sillimanite in only the northeastern section of the IPS suggest that higher temperatures of metamorphism were experienced there than elsewhere in the screen.

- The presence of anhedral, partially altered andalusite with euhedral sillimanite in the screen and similar observations of sillimanite and andalusite in other metasedimentary bodies suggests two separate stages of contact metamorphism occurred. Andalusite formed during an earlier stage, lower temperature metamorphism, probably resulting from intrusion of the YVIS. It then reacted to sillimanite during a later, higher temperature metamorphism, probably from the intrusion of the relatively more mafic Glen Aulin granodiorite of the TIS.

- Variation in $\mathrm{Al}$ vs. Fe between concentric zones within the $\sim 3-\mathrm{cm}$ diameter garnet from the megaskarn of the NE screen may be evidence that the metasomatic fluid forming the skarn came in distinct pulses with the source chemical composition (the TIS magma) changing over time. The changing chemical composition may have been due to fresh pulses of magma and/or minerals crystallizing in the magma over time and removing chemical components from the fluid.

- Results from pseudosection modeling from locations spanning the north and central sections of the NE screen generally support the observation of higher temperatures of metamorphism to the north, NE of May Lake, and lower temperatures to the south. Estimated minimum temperatures for the NE screen 
based on an assumed minimum pressure of $\sim 2.5$ kbars range from $540-617^{\circ} \mathrm{C}$, which is consistent with the temperature estimate of Rose (1957a) based on microcline composition $\left(540^{\circ} \mathrm{C}\right)$.

- Results from stable isotope data suggest that rock permeability and preexisting anisotropies are the strongest factors controlling fluid infiltration and isotopic depletion through the contact aureole, not proximity to granitic contacts. Calcite from marble adjacent to more permeable rock (calc-silicate hornfels, metapelites, and quartzites) or to structural anisotropies such as large amphibolite dikes and heavily folded areas, show much more depletion in $\delta^{18} \mathrm{O}$ and $\delta^{13} \mathrm{C}$. Calcite from marble located within the relatively uniform, continuous stratigraphic section of marble that makes up the southwestern section of the screen show stable isotope values that are largely unshifted from Ordovician marine carbonate values. Lower $\delta^{18} \mathrm{O}$ and $\delta^{13} \mathrm{C}$ of calcite from marbles and calc-silicate rocks in the northeast than in the southwest suggest less (or less isotopically distinct) fluid permeated the thick marble units of the southwest.

\section{Recommendations for Further Work}

Acquiring $\delta^{18} \mathrm{O}$ data from silicate minerals throughout the May Lake IPS would provide a more detailed map of isotopic depletion and assist in determining the source and composition of the infiltrating fluid and the geometry of fluid flow. Silicate mineral $\delta^{18} \mathrm{O}$ data would also be valuable for calculating the temperature of stable isotope equilibration between quartz and calcite in order to more specifically determine P-T conditions of metasomatism. Fluid inclusion analysis of garnet and epidote from skarn 
locations is also recommended in order to characterize the fluid composition during skarn formation. $\delta^{18} \mathrm{O}$ analysis and fluid inclusion analysis of zoning in the $>3 \mathrm{~cm}$ large skarn garnets located at Station ML 28 may provide information on changes in the metasomatic fluid composition over time. Additional electron microprobe analysis and/or X-ray diffraction could be used to better identify minerals present in fine-grained hornfels samples, allowing for a more robust interpretation of pseudosection modeling results. 


\section{REFERENCES CITED}

Allmendinger, R.W., Cardoza, N., and Fisher, D., 2012, Structural geology algorithms: Vectors and tensors: Cambridge, England, Cambridge University Press, 289 p.

Anenburg, M., and Katzir, Y., 2014, Muscovite dehydration melting in Si-rich metapelites: microstructural evidence from trondhjemitic migmatites, Roded, Southern Israel: Mineralogy and Petrology, v. 108, p. 137-152.

Auzanneau, E., Schmidt, M.W., Vielzeuf, D., and Connolly, J.A.D., 2010, Titanium in phengite: a geobarometer for high temperature eclogites: Contributions to Mineralogy and Petrology, v. 159, p. 1-24.

Bindeman, I., 2008, Oxygen isotopes in mantle and crustal magmas as revealed by single crystal analysis: Reviews in Mineralogy and Geochemistry, v. 69, p. 445-478.

Cardozo, N., and Allmendinger, R.W., 2013, Spherical projections with OSXStereonet: Computers \& Geosciences, v. 51, p. 193-205.

Chapman, A.D., Ernst, W.G., Gottlieb, E., Powerman, and V., Metzger, E.P., 2015. Detrital zircon geochronology of Neoproterozoic-Lower Cambrian passivemargin strata of the White-Inyo Range, east-central California: Implications for the Mojave- Snow Lake fault hypothesis: Geological Society of America Bulletin, v. 127, no. 7-8, p. 926-944.

Coggon, R. and Holland, T.J.B., 2002, Mixing properties of phengitic micas and revised garnet-phengite thermobarometers: Journal of Metamorphic Geology, v. 20, p. 683-696.

Coleman, D.S., Gray, W., and Glazner, A.F., 2004, Rethinking the emplacement and evolution of zoned plutons: Geochronologic evidence for incremental assembly of the Tuolumne Intrusive Suite, California: Geology, v. 32, p. 433-436.

Connolly, J.A.D., 1990, Multivariable phase-diagrams - an algorithm based on generalized thermodynamics: American Journal of Science, v. 290, p. 666-718.

Connolly, J.A.D., 2009, The geodynamic equation of state: What and how, Geochemistry, Geophysics, Geosystems, v. 10, p. Q10014.

Connolly, J.A.D., and Petrini, K., 2002, An automated strategy for calculation of phase diagram sections and retrieval of rock properties as a function of physical conditions: Journal of Metamorphic Petrology, v. 20, p. 697-708. 
Davis, S.R., and Ferry, J.M., 1993, Fluid infiltration during contact metamorphism of interbedded marble and calc-silicate hornfels, Twin Lakes area, central Sierra Nevada, California: Journal of Metamorphic Geology, v. 11, p. 71-88.

Drahota, P., and Ackerman, L., 2004, Regionally metamorphosed skarns of the Bohemian Massif, and the Kutna Hora Ore District: Joint Society for Geology Applied to Mineral Deposits Student Chapter Field Trip Guidebook, p. 1-34.

Dyer, B., Lee, C.-T.A., Leeman, W.P., and Tice, M., 2011, Open-system behavior during pluton-wall-rock interaction as constrained from a study of endoskarns in the Sierra Nevada batholith, California: Journal of Petrology, v. 52, p. 1987-2008.

Faure, G., and Mensing, T.M., 2005, Isotopes: Principles and Applications: Hoboken, New Jersey, John Wiley \& Sons, Inc., 897 p.

Ferry, J.M., Sorensen, S.S., and Rumble III, D., 1998, Structurally controlled fluid flow during contact metamorphism in the Ritter Range pendant, California, USA: Contributions to Mineral Petrology, v. 130, p. 358-378.

Ferry, J.M., Wing, B.A., and Rumble III, D., 2001, Formation of wollastonite by chemically reactive fluid flow during contact metamorphism, Mt. Morrision pendant, Sierra Nevada, California, USA: Journal of Petrology, v. 42, p. 17051728 .

Ferry, J.M., Ushikubo, T, and Valley, J.W., 2011, Formation of forsterite by silicification of dolomite during contact metamorphism: Journal of Petrology, v. 52, p. 16191640 .

Henry, D.J., Guidotti, C.V., and Thomson, J.A., 2005, The Ti-saturation surface for lowto-medium pressure metapelitic biotites: Implications for geothermometry and Tisubstitution mechanisms: American Mineralogist, v. 90, p. 316-328.

Holland, T.J.B. and Powell, R., 1996, Thermodynamics of order-disorder in minerals. 2. Symmetric formalism applied to solid solutions: American Mineralogist, v. 81, p. 1425-1437.

Holland, T.J.B. and Powell, R., 1998, An internally consistent thermodynamic data set for phases of petrological interest: Journal of Metamorphic Geology, v. 16, p. 309-343.

Holland, T. and Powell, R., 2001, Calculation of phase relations involving haplogranitic melts using an internally consistent thermodynamic dataset: Journal of Petrology, v. 42, p. 673-683. 
Jamtveit, B., and Austrheim, H., 2010, Metamorphism: the role of fluids: Elements, v. 6, p. $153-158$.

Johnson, B.L., 2013, Structure, Construction, and Emplacement of the Yosemite Valley Intrusive Suite and the Yosemite Creek Granodiorite in the Central Sierra Nevada Batholith [M.S. thesis]: San Jose, California, San Jose State University, 89 p.

Kerrick, D.M., 1977, The genesis of zoned skarns in the Sierra Nevada, California: Journal of Petrology, v. 18, p. 144-181.

Kretz, R., 1983, Symbols of rock-forming minerals: American Mineralogist, v. 68, p. 277-279.

Lackey, J.S., and Valley, J.W., 2004, Complex patterns of fluid flow during wollastonite formation in calcareous sandstones at Laurel Mountain, Mt. Morrison pendant, California: Geological Society of America Bulletin, v. 116, p. 76-93.

Lahren, M.M., and Schweickert, R.A., 1989, Proterozoic and Lower Cambrian miogeoclinal rocks of Snow Lake pendant, Yosemite-Emigrant Wilderness, Sierra Nevada, California: Evidence for major Early Cretaceous dextral translation: Geology, v. 17, p. 156-160.

Memeti, V., Gehrels, G.E., Paterson, S.R., Thompson, J.M., Mueller, R.M., and Pignotta, G.S., 2010, Evaluating the Mojave-Snow Lake fault hypothesis and origins of central Sierran metasedimentary pendant strata using detrital zircon provenance analyses: Lithosphere, v. 2, p. 341-360.

Memeti, V., Paterson, S.R., Economos, R., Erdmann, S., and Miller, R.B., 2012, Geology of the Benson Lake Pendant, Western Yosemite National Park, Central Sierra Nevada: Geological Society of America Digital Maps and Charts Series 13.

Mills, R.D., 2007, Scale of pluton/ wall rock interaction near May Lake, Yosemite National Park, CA, USA [Master of Science thesis]: University of North Carolina, Chapel Hill, 49 p.

Mottram, C.M., Warren, C.J., Regis, D., Roberts, N.M.W., Harris, N.B.W., Argles, T.W., and Parrish, R.R., Developing an inverted Barrovian sequence; insights from monazite petrochronology: Earth and Planetary Science Letters, v. 403, p. 418431.

Nabelek, P.I., and Morgan, S.S., 2012, Metamorphism and fluid flow in the contact aureole of the Eureka Valley-Joshua Flat-Beer Creek pluton, California: Geological Society of America Bulletin, v. 124, p. 228-239. 
Newton, R.C., Charlu, T.V., and Kleppa, O.J., 1980, Thermochemistry of the high structural state plagioclases: Geochemica Cosmochimica Acta, v. 44, p. 933-941.

Petsche, J., 2008, Structure of the Sentinel Granodiorite, Yosemite National Park, California [M.S. thesis]: San Jose, California, San Jose State University, 102 p.

Putnis, A., and Austrheim, H., 2010, Fluid-induced processes: metasomatism and metamorphism: Geofluids, v. 10, p. 254-269.

Rose, R.L., 1957a, Geology of the May Lake Area, Yosemite National Park [Ph.D. thesis]: University of California, Berkeley, 219 p.

Rose, R.L., 1957b, Andalusite and corundum bearing pegmatites in Yosemite National Park, California. American Mineralogist v. 42, p. 635-647.

Saleeby, J.B., and Busby, C., 1993, Paleogeographic and tectonic setting of axial and western metamorphic framework rocks of the southern sierra Nevada, California: in Dunn, G., and McDougall, K., eds., 1993, Mesozoic Paleogeography of the Western United States-II: Pacific Section SEPM, Book 71, p. 197-226.

Sengupta, P., Dutta, U., Bhui, U.K., and Mukhopadhyay, D., Genesis of wollastonite- and grandite-rich skarns in a suite of marble-calc-silicate rocks from Sittampundi, Tamil Nadu: constraints on the P-T-fluid regime in parts of the Pan-African mobile belt of South India: Mineralogy and Petrology, v. 95, p. 179-200.

Siivola, J., and Schmid, R., 2007, Recommendations by the IUGS Subcommission on the Systematics of Metamorphic Rocks: List of mineral abbreviations. Web version 01.02.07 (https://www.bgs.ac.uk/scmr/docs/papers/paper_12.pdf).

Stern, L.A., Chamberlain, C.P., Barnett, D.E., and Ferry, J.M., 1992, Stable isotope evidence for regional-scale fluid migration in Barrovian metamorphic terrane, Vermont, USA: Contributions to Mineral Petrology, v. 112, p. 475-489.

Tajcmanová, L., Connolly, J.A.D., and Cesare, B., 2009, A thermodynamic model for titanium and ferric iron solution in biotite: Journal of Metamorphic Geology, v. 27, p. 153-164.

Taylor, R.Z., 2004, Structure and stratigraphy of the May Lake interpluton screen, Yosemite National Park, California [M.S. thesis]: University of North Carolina, Chapel Hill, 55 p.

Timon, S.M., et al., 2007, Contact metamorphism in the Los Santos W skarn (NW Spain): Mineralogy and Petrology, v. 90, p. 109-140. 
Thompson, A.B., and Connolly, J.A.D., 1992, Migration of metamorphic fluid: some aspects of mass and heat transfer: Earth-Science Reviews, v. 32, p. 107-121.

Valley, J.W., 1986, Stable isotope geochemistry of metamorphic rocks, in Stable Isotopes in High Temperature Processes (J.W. Valley, H.P, Taylor, Jr., and J.R. O’Neil, eds.), Mineralogical Society of America, Reviews in Mineralogy, v. 16, p. 445489.

Van Dyne, A., Structure and Emplacement of Cretacteous Plutons in Northwest Yosemite National Park, California [M.S. thesis]: San Jose, California, San Jose State University, $74 \mathrm{p}$.

Veizer, J., Ala, D., Azmy, K., Bruckschen, P., Buhl, D., Bruhn, F., Carden, G.A.F., Diener, A., Ebneth, S., Godderis, Y., Jasper, T., Korte, C., Pawellek, F., Podlaha, O.G., and Strauss, H., $1999,{ }^{87} \mathrm{Sr} /{ }^{86} \mathrm{Sr}, \delta^{13} \mathrm{C}$ and $\delta^{13} \mathrm{O}$ evolution of Phanerozoic seawater, Chemical Geology, v. 161, p. 59-88.

Waldbaum, D.R. and Thompson, J.B., 1968, Mixing properties of sanidine crystalline solutions: II. Calculations based on volume data: American Mineralogist, v. 53, p. 2000-2017.

Webber, C.E., Candela, P.A., Piccoli, P.M., and Simon, A.C., 2001, Generation of granitic dikes: can texture, mineralogy, and geochemistry be used as guides to determine the mechanisms of diking?: Geological Society of America Abstracts with Programs, v. 33, p. 138.

White, R.W., Powell, R., and Holland, T.J.B., 2001, Calculation of partial melting equilibria in the system Na2O-CaO-K2O-FeO-MgO-A12O3-SiO2-H2O (NCKFMASH): Journal of Metamorphic Geology, v. 19, p. 139-153.

White, R.W., Powell, R., Holland, T.J.B., and Worley, B., The effects of $\mathrm{TiO}_{2}$ and $\mathrm{Fe}_{2} \mathrm{O}_{3}$ on metapelitic assemblages at greenschist and amphibolite facies conditions: mineral equilibria calculations in the system $\mathrm{K}_{2} \mathrm{O}-\mathrm{FeO}-\mathrm{MgO}-\mathrm{Al}_{2} \mathrm{O}_{3}-\mathrm{SiO}_{2}-\mathrm{H}_{2} \mathrm{O}-$ $\mathrm{TiO}_{2}-\mathrm{Fe}_{2} \mathrm{O}_{3}$ : Journal of Metamorphic Geology, v. 18, p. 497-511. 


\section{APPENDIX A: LIST OF MINERAL ABBREVIATIONS}

The following is a list of abbreviations used for minerals mentioned in this study, with the exception of those presented in the pseudosection diagrams. This list is consistent with the recommendations of the International Union of Geologic Sciences (IUGS) Subcommission on the Systematics of Metamorphic Rocks (Siivola and Schmid, 2007), and based on the original mineral abbreviations list by Kretz (1983). For mineral abbreviations used in the pseudosection diagrams, see Appendix C.

Table A-1. List of Mineral Abbreviations

\begin{tabular}{|c|c|c|c|}
\hline Mineral & Abbreviation & Mineral & Abbreviation \\
\hline Actinolite & Act & Carbonate Mineral & $\mathrm{Cb}$ \\
\hline Albite & $\mathrm{Ab}$ & Chlorite & Chl \\
\hline Alkalifeldspar & Afs & Chondrodite & Chn \\
\hline Almandine & Alm & Clinoamphibole & Cam \\
\hline Amphibole & Am & Clinopyroxene & Cpx \\
\hline Andalusite & And & Clinozoisite & $\mathrm{Czo}$ \\
\hline Andradite & Adr & Cordierite & Crd \\
\hline Annite & Ann & Corundum & Crn \\
\hline Anorthite & An & Cummingtonite & Cum \\
\hline Apatite & Ap & Diopside & Di \\
\hline Augite & Aug & Dolomite & Dol \\
\hline Biotite & $\mathrm{Bt}$ & Epidote & Ep \\
\hline Brucite & $\mathrm{Brc}$ & Feldspar & Fsp \\
\hline Calcite & Cal & Garnet & Grt \\
\hline
\end{tabular}


Table A-1 (continued). List of Mineral Abbreviations

\begin{tabular}{|c|c|c|c|}
\hline Mineral & Abbreviation & Mineral & Abbreviation \\
\hline Graphite & $\mathrm{Gr}$ & Plagioclase & $\mathrm{Pl}$ \\
\hline Grossular & Grs & Pyrope & $\operatorname{Prp}$ \\
\hline Hematite & Hem & Quartz & Qtz \\
\hline Hedenbergite & $\mathrm{Hd}$ & Rutile & $\mathrm{Rt}$ \\
\hline Hornblende & $\mathrm{Hbl}$ & Sillimanite & Sil \\
\hline Ilmenite & $\mathrm{Ilm}$ & Spessartine & Sps \\
\hline K-feldspar & Kfs & Spinel & Spl \\
\hline Magnesiohornblende & $\mathrm{Mg}-\mathrm{Hbl}$ & Titanite & Ttn \\
\hline Magnetite & Mag & Tourmaline & Tur \\
\hline Mica & Mca & Tremolite & $\operatorname{Tr}$ \\
\hline Microcline & $\mathrm{Mc}$ & Tschermakite & Ts \\
\hline Muscovite & Ms & Uvarovite & Uvt \\
\hline opaque minerals & opq & Vesuvianite & Ves \\
\hline Orthoclase & Or & White Mica & Wmca \\
\hline Orthopyroxene & Opx & Wollastonite & Wo \\
\hline Phlogopite & Phl & Zircon & $\mathrm{Zrn}$ \\
\hline
\end{tabular}




\section{APPENDIX B: ELECTRON MICROPROBE MINERAL CHEMISTRY}

Table B-1. Sample names, rock types, and minerals analyzed in microprobed samples.

\begin{tabular}{|c|c|c|c|c|c|c|c|}
\hline Sample & Rock types microprobed & Mir & rals 1 & ropr & & & \\
\hline ML 6-2 & Metapelite & & & & & & $\mathrm{bt}$ \\
\hline ML 19-2 & Calc-silicate hornfels & & cpx & grt & $\mathrm{pl}$ & & \\
\hline ML 21-1 & $\begin{array}{l}\mathrm{Qtz}+\mathrm{kfs}+\mathrm{bt}+\mathrm{sil}+\text { and } \\
\text { pegmatite }\end{array}$ & & & & & $\mathrm{kfs}$ & \\
\hline ML 21-2 & $\begin{array}{l}\text { Calc-silicate hornfels near } \\
\text { pegmatite }\end{array}$ & & $\operatorname{cpx}$ & & & & \\
\hline ML 21-3 & $\begin{array}{l}\text { Endoskarn at hornfels } \\
\text { contact with pegmatite }\end{array}$ & ep & & & $\mathrm{pl}$ & & \\
\hline ML 23-1 & Calc-silicate hornfels & & cpx & grt & & & \\
\hline ML 23-4 & Calc-silicate hornfels & & $\operatorname{cpx}$ & & $\mathrm{pl}$ & & \\
\hline & Granitic pegmatite & & & & $\mathrm{pl}$ & $\mathrm{kfs}$ & \\
\hline ML 25-1 & Calc-silicate hornfels & & cpx & grt & $\mathrm{pl}$ & & \\
\hline ML 28-2 & Exoskarn & & & grt & & & \\
\hline ML 28-3 & Exoskarn & ep & $\operatorname{cpx}$ & & & & \\
\hline ML 28-5 & Exoskarn & ep & cpx & grt & & & \\
\hline ML 28-6 & $\begin{array}{l}\text { Calc-silicate hornfels } \\
\text { xenolith }\end{array}$ & & $\operatorname{cpx}$ & & & & \\
\hline & Granodiorite endoskarn & & cpx & grt & $\mathrm{P}^{\mathrm{T}}$ & & \\
\hline & Amphibolite inclusion & & & & $\mathrm{pl}$ & $\mathrm{hbl}$ & \\
\hline ML 28-7A & Endoskarn & & cpx & & & & \\
\hline & Granodiorite & & & & & $\mathrm{hbl}$ & bt \\
\hline ML 28-7B & Endoskarn & ep & cpx & & & & \\
\hline ML 28-12A & Exoskarn & & $\operatorname{cpx}$ & & & & \\
\hline ML 28-12B & Endoskarn & & cpx & & & & \\
\hline
\end{tabular}


Table B-2. Biotite mineral chemistry, metapelite sample ML 6-2.

\begin{tabular}{|c|c|c|c|c|c|c|c|c|c|c|}
\hline Grain & 1 & 2 & 3 & 4 & 5 & 6 & 7 & 8 & 9 & 10 \\
\hline \multicolumn{11}{|c|}{ Weight percent Oxide } \\
\hline $\mathrm{SiO}_{2}$ & 34.9 & 34.7 & 34.7 & 34.4 & 34.4 & 34.2 & 34.1 & 34.6 & 34.7 & 34.8 \\
\hline $\mathrm{TiO}_{2}$ & 3.41 & 3.70 & 3.84 & 3.75 & 3.30 & 4.04 & 3.81 & 3.81 & 3.84 & 3.54 \\
\hline $\mathrm{Al}_{2} \mathrm{O}_{3}$ & 19.5 & 19.3 & 19.0 & 19.4 & 19.5 & 19.1 & 19.2 & 19.4 & 19.1 & 19.3 \\
\hline $\mathrm{FeO}^{\text {total* }}$ & 21.6 & 21.5 & 21.1 & 22.0 & 21.7 & 21.2 & 21.2 & 21.3 & 21.2 & 21.6 \\
\hline $\mathrm{MnO}$ & 0.13 & 0.11 & 0.14 & 0.14 & 0.10 & 0.09 & 0.13 & 0.11 & 0.15 & 0.09 \\
\hline $\mathrm{MgO}$ & 7.21 & 7.11 & 6.97 & 7.01 & 7.23 & 7.04 & 7.06 & 6.88 & 6.96 & 7.13 \\
\hline $\mathrm{CaO}$ & 0.01 & 0.01 & 0.02 & 0.04 & 0.01 & 0.00 & 0.00 & 0.03 & 0.00 & 0.01 \\
\hline $\mathrm{Na}_{2} \mathrm{O}$ & 0.21 & 0.26 & 0.25 & 0.22 & 0.25 & 0.20 & 0.24 & 0.20 & 0.20 & 0.19 \\
\hline $\mathrm{K}_{2} \mathrm{O}$ & 9.24 & 9.29 & 9.12 & 9.24 & 9.37 & 9.21 & 9.10 & 9.18 & 9.30 & 9.16 \\
\hline $\mathrm{Cr}_{2} \mathrm{O}_{3}$ & 0.05 & 0.06 & 0.03 & 0.04 & 0.08 & 0.06 & 0.08 & 0.05 & 0.07 & 0.04 \\
\hline $\mathrm{BaO}$ & 0.17 & 0.20 & 0.17 & 0.23 & 0.19 & 0.22 & 0.15 & 0.18 & 0.24 & 0.22 \\
\hline $\mathrm{F}$ & 0.02 & 0.04 & 0.08 & 0.04 & 0.07 & 0.06 & 0.09 & 0.03 & 0.12 & 0.01 \\
\hline $\mathrm{Cl}$ & 0.12 & 0.13 & 0.13 & 0.11 & 0.15 & 0.13 & 0.14 & 0.17 & 0.14 & 0.13 \\
\hline Total & 96.5 & 96.4 & 95.5 & 96.5 & 96.3 & 95.5 & 95.2 & 95.8 & 95.9 & 96.2 \\
\hline \multicolumn{11}{|c|}{ Atoms per formula unit } \\
\hline \multicolumn{11}{|l|}{ T-site } \\
\hline $\mathrm{Si}$ & 2.66 & 2.65 & 2.67 & 2.63 & 2.64 & 2.64 & 2.64 & 2.65 & 2.66 & 2.66 \\
\hline $\mathrm{Al}^{\mathrm{IVt}}$ & 1.34 & 1.35 & 1.33 & 1.37 & 1.36 & 1.36 & 1.36 & 1.35 & 1.34 & 1.34 \\
\hline Sum $(T)$ & 4.00 & 4.00 & 4.00 & 4.00 & 4.00 & 4.00 & 4.00 & 4.00 & 4.00 & 4.00 \\
\hline \multicolumn{11}{|l|}{ M-site } \\
\hline $\mathrm{Ti}$ & 0.20 & 0.21 & 0.22 & 0.22 & 0.19 & 0.23 & 0.22 & 0.22 & 0.22 & 0.20 \\
\hline $\mathrm{Al}^{\mathrm{III} \mathrm{t}}$ & 0.41 & 0.39 & 0.39 & 0.38 & 0.40 & 0.37 & 0.38 & 0.40 & 0.39 & 0.40 \\
\hline $\mathrm{Fe}^{2+}$ & 1.37 & 1.37 & 1.36 & 1.41 & 1.39 & 1.37 & 1.37 & 1.37 & 1.36 & 1.38 \\
\hline $\mathrm{Mn}$ & 0.01 & 0.01 & 0.01 & 0.01 & 0.01 & 0.01 & 0.01 & 0.01 & 0.01 & 0.01 \\
\hline $\mathrm{Mg}$ & 0.82 & 0.81 & 0.80 & 0.80 & 0.83 & 0.81 & 0.81 & 0.79 & 0.80 & 0.81 \\
\hline $\mathrm{Cr}$ & 0.00 & 0.00 & 0.00 & 0.00 & 0.01 & 0.00 & 0.00 & 0.00 & 0.00 & 0.00 \\
\hline Sum (M) & 2.81 & 2.79 & 2.78 & 2.81 & 2.81 & 2.79 & 2.80 & 2.79 & 2.78 & 2.80 \\
\hline \multicolumn{11}{|l|}{ A-site } \\
\hline $\mathrm{Ca}$ & 0.00 & 0.00 & 0.00 & 0.00 & 0.00 & 0.00 & 0.00 & 0.00 & 0.00 & 0.00 \\
\hline $\mathrm{Na}$ & 0.03 & 0.04 & 0.04 & 0.03 & 0.04 & 0.03 & 0.04 & 0.03 & 0.03 & 0.03 \\
\hline K & 0.90 & 0.90 & 0.90 & 0.90 & 0.92 & 0.91 & 0.90 & 0.90 & 0.91 & 0.89 \\
\hline $\mathrm{Ba}$ & 0.01 & 0.01 & 0.01 & 0.01 & 0.01 & 0.01 & 0.01 & 0.01 & 0.01 & 0.01 \\
\hline Sum (A) & 0.94 & 0.95 & 0.95 & 0.94 & 0.97 & 0.95 & 09.5 & 0.95 & 0.95 & 0.93 \\
\hline Cation Total & 7.74 & 7.74 & 7.72 & 7.75 & 7.77 & 7.74 & 7.74 & 7.72 & 7.73 & 7.73 \\
\hline $\mathrm{Mg} /\left(\mathrm{Mg}+\mathrm{Fe}^{2+}\right)$ & 0.37 & 0.37 & 0.37 & 0.36 & 0.37 & 0.37 & 0.37 & 0.37 & 0.37 & 0.37 \\
\hline $\mathrm{Na} /(\mathrm{Na}+\mathrm{K})$ & 0.03 & 0.04 & 0.04 & 0.03 & 0.04 & 0.03 & 0.04 & 0.03 & 0.03 & 0.03 \\
\hline
\end{tabular}


Table B-3. Calc-silicate hornfels clinopyroxene mineral chemistry. Each clinopyroxene result is the average of five to eight grains per sample and 5 spots per grain.

\begin{tabular}{|c|c|c|c|c|c|}
\hline "Sample ID & ML 21-2 & ML 19-2 & ML 23-1 & ML 23-4 & ML 25-1 \\
\hline \multicolumn{6}{|c|}{ Weight Percent Oxide } \\
\hline $\mathrm{SiO}_{2}$ & 48.67 & 53.00 & 51.49 & 51.56 & 51.58 \\
\hline $\mathrm{TiO}_{2}$ & 0.59 & 0.08 & 0.09 & 0.07 & 0.02 \\
\hline $\mathrm{Al}_{2} \mathrm{O}_{3}$ & 6.19 & 0.76 & 1.29 & 0.98 & 0.65 \\
\hline $\mathrm{FeO}$ & 4.25 & 7.01 & 10.61 & 11.46 & 12.66 \\
\hline $\mathrm{MnO}$ & 0.19 & 0.32 & 0.69 & 0.68 & 0.85 \\
\hline $\mathrm{MgO}$ & 14.34 & 13.64 & 11.01 & 10.81 & 9.88 \\
\hline $\mathrm{CaO}$ & 25.77 & 25.20 & 24.60 & 24.18 & 24.18 \\
\hline $\mathrm{Na}_{2} \mathrm{O}$ & 0.01 & 0.12 & 0.18 & 0.21 & 0.12 \\
\hline $\mathrm{K}_{2} \mathrm{O}$ & 0.01 & 0.00 & 0.00 & 0.00 & 0.01 \\
\hline $\mathrm{Cr}_{2} \mathrm{O}_{3}$ & 0.01 & 0.04 & 0.01 & 0.02 & 0.01 \\
\hline Total & 100.0 & 100.2 & 99.97 & 99.96 & 99.97 \\
\hline \multicolumn{6}{|c|}{ Atoms per formula unit } \\
\hline $\mathrm{Si}$ & 1.80 & 1.97 & 1.96 & 1.97 & 1.98 \\
\hline $\mathrm{Ti}$ & 0.02 & 0.00 & 0.00 & 0.00 & 0.00 \\
\hline Al & 0.27 & 0.03 & 0.06 & 0.04 & 0.03 \\
\hline $\mathrm{Fe}^{2+}$ & 0.13 & 0.22 & 0.34 & 0.37 & 0.41 \\
\hline $\mathrm{Mn}$ & 0.01 & 0.01 & 0.02 & 0.02 & 0.03 \\
\hline $\mathrm{Mg}$ & 0.79 & 0.76 & 0.62 & 0.61 & 0.56 \\
\hline $\mathrm{Ca}$ & 1.02 & 1.01 & 1.00 & 0.99 & 0.99 \\
\hline $\mathrm{Na}$ & 0.00 & 0.01 & 0.01 & 0.02 & 0.01 \\
\hline $\mathrm{K}$ & 0.00 & 0.00 & 0.00 & 0.00 & 0.00 \\
\hline $\mathrm{Cr}$ & 0.00 & 0.00 & 0.00 & 0.00 & 0.00 \\
\hline Cation Total & 4.05 & 4.01 & 4.02 & 4.02 & 4.01 \\
\hline$\% \mathrm{Di}$ & 85.9 & 77.6 & 64.6 & 62.2 & 57.7 \\
\hline \%Tschermak ${ }^{*}$ & 29.0 & 2.52 & 4.62 & 2.99 & 2.16 \\
\hline \multicolumn{6}{|c|}{$\begin{array}{l}\text { *Fraction of Tschermak substitution = Al apfu *100 / }\left(\mathrm{Fe}^{2+} \text { apfu }+\mathrm{Si}^{4+} \text { apfu }-1\right):\left(1 \mathrm{Al}^{(\mathrm{VI})} \leftrightarrow 1 \mathrm{Fe}^{2+(\mathrm{VI})} \text { and } 1\right. \\
\left.\mathrm{Al}(\mathrm{IV}) \leftrightarrow 1 \mathrm{Si}^{4+(\mathrm{V})}\right)\end{array}$} \\
\hline
\end{tabular}


Table B-4. Calc-silicate hornfels garnet mineral chemistry.

\begin{tabular}{|c|c|c|c|c|c|c|c|c|c|c|c|c|c|}
\hline \multirow[b]{3}{*}{ Grain } & \multicolumn{4}{|c|}{ ML 19-2 } & \multicolumn{5}{|c|}{ ML 23-1 } & \multicolumn{4}{|c|}{ ML 25-1 } \\
\hline & \multirow[b]{2}{*}{5} & \multirow[b]{2}{*}{6} & \multirow[b]{2}{*}{7} & \multirow[b]{2}{*}{8} & \multicolumn{2}{|c|}{ Band 1} & \multicolumn{2}{|c|}{ Band 2} & \multirow{2}{*}{$\frac{\text { Band } 3}{5}$} & \multirow[b]{2}{*}{7} & \multirow[b]{2}{*}{9} & \multirow[b]{2}{*}{10} & \multirow[b]{2}{*}{11} \\
\hline & & & & & 1 & $\overline{2}$ & 3 & 4 & & & & & \\
\hline \multicolumn{14}{|c|}{ Weight Percent Oxide } \\
\hline $\mathrm{SiO}_{2}$ & 38.17 & 38.39 & 38.17 & 38.21 & 39.62 & 38.84 & 37.68 & 37.52 & 38.46 & 36.38 & 36.49 & 36.35 & 36.74 \\
\hline $\mathrm{TiO}_{2}$ & 0.43 & 0.75 & 0.55 & 0.61 & 0.28 & 0.45 & 0.87 & 0.77 & 0.40 & 0.64 & 0.59 & 1.49 & 0.63 \\
\hline $\mathrm{Al}_{2} \mathrm{O}_{3}$ & 15.08 & 15.19 & 15.47 & 14.91 & 20.91 & 17.98 & 12.90 & 13.57 & 17.15 & 5.40 & 6.09 & 7.27 & 6.52 \\
\hline $\mathrm{FeO}^{\text {Total* }}$ & 9.56 & 9.16 & 8.76 & 9.41 & 2.41 & 5.90 & 11.95 & 11.51 & 6.91 & 20.96 & 19.91 & 18.29 & 19.95 \\
\hline $\mathrm{MnO}$ & 0.40 & 0.34 & 0.34 & 0.39 & 0.39 & 0.59 & 0.63 & 0.68 & 0.54 & 0.77 & 0.58 & 0.57 & 0.53 \\
\hline $\mathrm{MgO}$ & 0.16 & 0.19 & 0.17 & 0.16 & 0.02 & 0.05 & 0.21 & 0.19 & 0.04 & 0.09 & 0.10 & 0.08 & 0.10 \\
\hline $\mathrm{CaO}$ & 34.53 & 34.81 & 34.77 & 34.86 & 36.49 & 35.50 & 34.02 & 33.94 & 35.38 & 32.71 & 32.81 & 33.52 & 32.93 \\
\hline $\mathrm{Cr}_{2} \mathrm{O}_{3}$ & 0.09 & 0.09 & 0.11 & 0.11 & 0.00 & 0.00 & 0.02 & 0.02 & 0.02 & 0.22 & 0.20 & 0.02 & 0.07 \\
\hline Total $^{t}$ & 98.41 & 98.92 & 98.33 & 98.65 & 100.13 & 99.31 & 98.29 & 98.19 & 98.89 & 97.17 & 96.77 & 97.58 & 97.48 \\
\hline \multicolumn{14}{|c|}{ Atoms per formula unit } \\
\hline $\mathrm{Si}$ & 3.00 & 3.00 & 2.99 & 2.99 & 2.99 & 2.99 & 2.99 & 2.97 & 2.98 & 3.01 & 3.02 & 2.97 & 3.01 \\
\hline $\mathrm{Ti}$ & 0.03 & 0.04 & 0.03 & 0.04 & 0.02 & 0.03 & 0.05 & 0.05 & 0.02 & 0.04 & 0.04 & 0.09 & 0.04 \\
\hline $\mathrm{Al}$ & 1.40 & 1.40 & 1.43 & 1.38 & 1.86 & 1.63 & 1.21 & 1.27 & 1.57 & 0.53 & 0.59 & 0.70 & 0.63 \\
\hline $\mathrm{Fe}^{2+}$ & 0.07 & 0.08 & 0.06 & 0.06 & 0.03 & 0.04 & 0.08 & 0.07 & 0.03 & 0.09 & 0.09 & 0.08 & 0.11 \\
\hline $\mathrm{Fe}^{3+}$ & 0.55 & 0.51 & 0.51 & 0.56 & 0.12 & 0.34 & 0.71 & 0.69 & 0.42 & 1.36 & 1.28 & 1.17 & 1.26 \\
\hline $\mathrm{Mn}$ & 0.03 & 0.02 & 0.02 & 0.03 & 0.03 & 0.04 & 0.04 & 0.05 & 0.04 & 0.05 & 0.04 & 0.04 & 0.04 \\
\hline $\mathrm{Mg}$ & 0.02 & 0.02 & 0.02 & 0.02 & 0.00 & 0.01 & 0.02 & 0.02 & 0.00 & 0.01 & 0.01 & 0.01 & 0.01 \\
\hline $\mathrm{Ca}$ & 2.90 & 2.91 & 2.92 & 2.93 & 2.95 & 2.93 & 2.89 & 2.88 & 2.94 & 2.90 & 2.91 & 2.94 & 2.89 \\
\hline $\mathrm{Cr}$ & 0.01 & 0.01 & 0.01 & 0.01 & 0.00 & 0.00 & 0.00 & 0.00 & 0.00 & 0.01 & 0.01 & 0.00 & 0.00 \\
\hline Cation Total & 8 & 8 & 8 & 8 & 8 & 8 & 8 & 8 & 8 & 8 & 8 & 8 & 8 \\
\hline \%Alm & 2.41 & 2.79 & 2.05 & 1.98 & 0.96 & 1.46 & 2.71 & 2.32 & 0.87 & 2.79 & 3.09 & 2.53 & 3.61 \\
\hline$\%$ Pyr & 0.64 & 0.72 & 0.67 & 0.61 & 0.06 & 0.21 & 0.81 & 0.75 & 0.16 & 0.36 & 0.39 & 0.31 & 0.38 \\
\hline$\%$ Sps & 0.87 & 0.74 & 0.74 & 0.85 & 0.84 & 1.26 & 1.40 & 1.51 & 1.18 & 1.78 & 1.33 & 1.30 & 1.21 \\
\hline$\% G r s$ & 67.7 & 68.3 & 69.7 & 67.3 & 91.3 & 79.4 & 58.2 & 60.3 & 76.1 & 25.7 & 29.3 & 34.2 & 30.9 \\
\hline$\% A d r$ & 26.9 & 25.1 & 25.0 & 27.2 & 6.06 & 16.4 & 34.3 & 32.9 & 20.5 & 66.7 & 63.4 & 57.2 & 61.7 \\
\hline$\%$ Uvt & 0.27 & 0.26 & 0.32 & 0.34 & 0.01 & 0.00 & 0.05 & 0.04 & 0.04 & 0.70 & 0.66 & 0.06 & 0.23 \\
\hline \%Ca-Ti Grt & 1.24 & 2.14 & 1.59 & 1.76 & 0.79 & 1.27 & 2.52 & 2.19 & 1.14 & 1.96 & 1.82 & 4.45 & 1.92 \\
\hline
\end{tabular}

${ }^{*} \mathrm{All} \mathrm{Fe}$ was measured as $\mathrm{FeO}$. $\mathrm{Fe}^{3+}$ was calculated from $\mathrm{FeO}^{\text {total }}$ using stoichiometric charge balance based on 8 cations and 12 oxygen atoms.

${ }^{t}$ Low total weight percent oxide is due to high ferric iron content.

End-members: almandine (Alm), pyrope (Pyr), spessartine (Sps), grossular (Grs), andradite (Adr), uvarolite (Uvt), and Ca-Ti Garnet (Ca-Ti Grt). 
Table B-5. Calc-silicate hornfels plagioclase feldspar mineral chemistry.

\begin{tabular}{|c|c|c|c|c|c|}
\hline \multirow{2}{*}{ Sample ID } & \multicolumn{3}{|c|}{ ML 19-2 } & \multirow[t]{2}{*}{ ML 23-4 } & \multirow[t]{2}{*}{ ML 25-1 } \\
\hline & Band 1 & Band 2 & Band 3 & & \\
\hline Point & Avg of 3 & 3 & 4 & Avg of 3 & Avg of 9 \\
\hline \multicolumn{6}{|c|}{ Weight percent oxide } \\
\hline $\mathrm{SiO}_{2}$ & 43.37 & 45.51 & 45.55 & 57.56 & 43.72 \\
\hline $\mathrm{Al}_{2} \mathrm{O}_{3}$ & 36.97 & 35.24 & 35.73 & 27.55 & 36.62 \\
\hline $\mathrm{FeO}$ & 0.10 & 0.09 & 0.12 & 0.14 & 0.27 \\
\hline $\mathrm{CaO}$ & 19.66 & 17.89 & 17.89 & 8.42 & 19.25 \\
\hline $\mathrm{Na}_{2} \mathrm{O}$ & 0.29 & 1.27 & 1.29 & 6.76 & 0.53 \\
\hline $\mathrm{K}_{2} \mathrm{O}$ & 0.06 & 0.01 & 0.01 & 0.19 & 0.01 \\
\hline Total & 100.45 & 100.01 & 100.59 & 100.62 & 100.41 \\
\hline \multicolumn{6}{|c|}{ Atoms per formula unit } \\
\hline $\mathrm{Si}$ & 2.00 & 2.10 & 2.09 & 2.56 & 2.02 \\
\hline $\mathrm{Al}$ & 2.01 & 1.91 & 1.93 & 1.45 & 1.99 \\
\hline $\mathrm{Fe}^{2+}$ & 0.00 & 0.00 & 0.01 & 0.01 & 0.01 \\
\hline $\mathrm{Ca}$ & 0.97 & 0.88 & 0.88 & 0.40 & 0.95 \\
\hline $\mathrm{Na}$ & 0.03 & 0.11 & 0.12 & 0.58 & 0.05 \\
\hline $\mathrm{K}$ & 0.00 & 0.00 & 0.00 & 0.01 & 0.00 \\
\hline Cation Total & 5.01 & 5.01 & 5.01 & 5.01 & 5.01 \\
\hline$\% A n$ & 97.0 & 88.9 & 88.0 & 40.4 & 95.0 \\
\hline$\% \mathrm{Ab}$ & 3.00 & 11.1 & 12.0 & 58.6 & 5.00 \\
\hline$\%$ Or & 0.00 & 0.00 & 0.00 & 1.01 & 0.00 \\
\hline
\end{tabular}


Table B-6. Skarn sample ML 21-3 plagioclase feldspar and epidote mineral chemistry.

\begin{tabular}{|c|c|c|c|c|}
\hline $\begin{array}{l}\text { Mineral } \\
\text { Point }\end{array}$ & 1 & $\begin{array}{c}\mathrm{ML} \\
\text { Plagiocl } \\
2\end{array}$ & g1 & Epidote \\
\hline \multicolumn{5}{|c|}{ Weight percent oxide } \\
\hline $\mathrm{SiO}_{2}$ & 68.39 & 68.01 & 68.54 & 38.39 \\
\hline $\mathrm{TiO}_{2}$ & -- & -- & -- & 0.04 \\
\hline $\mathrm{Al}_{2} \mathrm{O}_{3}$ & 20.15 & 20.11 & 20.32 & 25.25 \\
\hline $\mathrm{FeO}^{\text {Total } *}$ & 0.0 & 0.00 & 0.0 & 10.43 \\
\hline $\mathrm{MnO}$ & -- & -- & -- & 0.35 \\
\hline $\mathrm{MgO}$ & -- & -- & -- & 0.05 \\
\hline $\mathrm{CaO}$ & 0.16 & 0.21 & 0.16 & 23.40 \\
\hline $\mathrm{Na}_{2} \mathrm{O}$ & 11.47 & 11.28 & 11.49 & 0.00 \\
\hline $\mathrm{K}_{2} \mathrm{O}$ & 0.05 & 0.06 & 0.04 & 0.00 \\
\hline $\mathrm{Cr}_{2} \mathrm{O}_{3}$ & -- & -- & -- & 0.00 \\
\hline Total & 100.22 & 99.67 & 100.56 & 97.92 \\
\hline \multicolumn{5}{|c|}{ Atoms per formula unit } \\
\hline $\mathrm{Si}$ & 2.98 & 2.98 & 2.97 & 3.00 \\
\hline $\mathrm{Ti}$ & -- & -- & -- & 0.00 \\
\hline $\mathrm{Al}^{\text {Total }}$ & 1.03 & 1.04 & 1.04 & 2.33 \\
\hline$A$ site $^{t}$ & -- & -- & -- & 2.00 \\
\hline$B$ site $t$ & -- & -- & -- & 0.33 \\
\hline $\mathrm{Fe}^{2+} \mathrm{Cl}$ & 0.00 & 0.00 & 0.00 & 0.00 \\
\hline $\mathrm{Fe}^{3+\star *}$ & -- & -- & -- & 0.68 \\
\hline $\mathrm{Mn}$ & -- & -- & -- & 0.02 \\
\hline $\mathrm{Mg}$ & -- & -- & -- & 0.01 \\
\hline $\mathrm{Ca}$ & 0.01 & 0.01 & 0.01 & 1.96 \\
\hline $\mathrm{Na}$ & 0.97 & 0.96 & 0.97 & 0.00 \\
\hline $\mathrm{K}$ & 0.00 & 0.00 & 0.00 & 0.00 \\
\hline $\mathrm{Cr}$ & -- & -- & -- & 0 \\
\hline Cation Total & 4.99 & 4.99 & 4.99 & 8.00 \\
\hline \%An & 0.8 & 1.0 & 0.7 & $\overline{--}$ \\
\hline$\% A b$ & 98.9 & 98.7 & 99.1 & -- \\
\hline$\%$ Or & 0.3 & 0.3 & 0.2 & -- \\
\hline$\%$ Clinozoisite $^{\mathrm{tt}}$ & -- & -- & -- & 31.9 \\
\hline \multicolumn{5}{|c|}{ 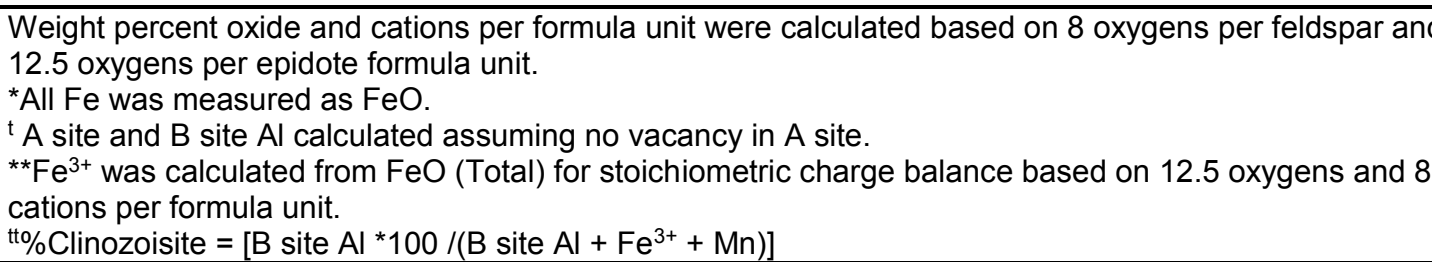 } \\
\hline
\end{tabular}


Table B-7. Endoskarn and exoskarn clinopyroxene chemistry. Each clinopyroxene grain chemistry reported is the average of 5 spots per grain. Where multiple grains were analyzed, the number of grains expressed by the average is indicated.

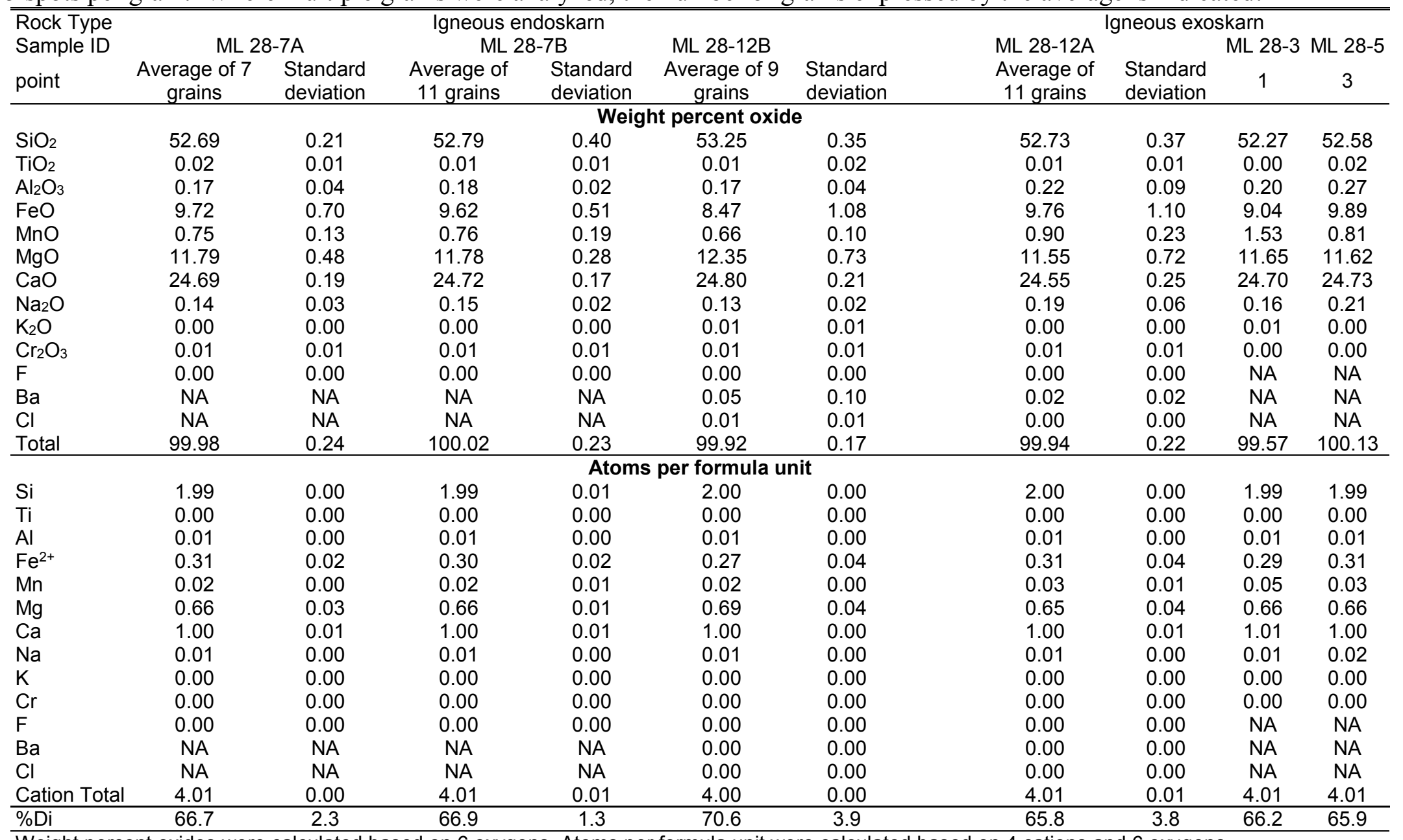

Weight percent oxides were calculated based on 6 oxygens. Atoms per formula unit were calculated based on 4 cations and 6 oxygens.

$\mathrm{NA}=$ Not Analyzed 
Table B-8. Hornblende and biotite microprobe data from granodiorite sample ML 28-7A.

\begin{tabular}{|c|c|c|c|c|c|c|c|}
\hline \multirow{2}{*}{$\begin{array}{l}\text { Mineral } \\
\text { point }\end{array}$} & \multicolumn{6}{|c|}{ Hornblende* } & \multirow{2}{*}{$\begin{array}{c}\text { Biotite } \\
2\end{array}$} \\
\hline & 1 & 3 & 4 & 5 & 7 & 8 & \\
\hline \multicolumn{8}{|c|}{ Weight percent oxide } \\
\hline $\mathrm{SiO}_{2}$ & 45.59 & 46.16 & 46.09 & 45.98 & 45.17 & 45.33 & 36.50 \\
\hline $\mathrm{TiO}_{2}$ & 1.32 & 1.22 & 1.20 & 1.35 & 1.46 & 1.33 & 2.78 \\
\hline $\mathrm{Al}_{2} \mathrm{O}_{3}$ & 7.57 & 7.49 & 7.69 & 7.69 & 7.83 & 7.81 & 13.80 \\
\hline $\mathrm{FeO}^{\text {Total } \mathrm{t}}$ & 19.01 & 17.36 & 17.52 & 18.55 & 18.34 & 17.48 & 23.85 \\
\hline $\mathrm{MnO}$ & 0.39 & 0.42 & 0.41 & 0.39 & 0.43 & 0.41 & 0.25 \\
\hline $\mathrm{MgO}$ & 10.16 & 11.32 & 11.20 & 10.49 & 10.37 & 11.22 & 9.36 \\
\hline $\mathrm{CaO}$ & 11.48 & 11.63 & 11.70 & 11.64 & 11.56 & 11.58 & 0.04 \\
\hline $\mathrm{Na}_{2} \mathrm{O}$ & 1.66 & 1.71 & 1.74 & 1.72 & 1.76 & 1.79 & 0.03 \\
\hline $\mathrm{K}_{2} \mathrm{O}$ & 0.85 & 0.82 & 0.82 & 0.84 & 0.92 & 0.90 & 9.31 \\
\hline $\mathrm{Cr}_{2} \mathrm{O}_{3}$ & 0.02 & 0.00 & 0.00 & 0.02 & 0.00 & 0.02 & 0.00 \\
\hline $\mathrm{F}$ & 0.00 & 0.07 & 0.06 & 0.05 & 0.00 & 0.08 & 0.23 \\
\hline $\mathrm{Ba}$ & NA & NA & NA & NA & NA & NA & 0.16 \\
\hline $\mathrm{Cl}$ & NA & NA & NA & NA & NA & NA & 0.10 \\
\hline Total & 98.05 & 98.18 & 98.42 & 98.71 & 97.83 & 97.92 & 96.28 \\
\hline \multicolumn{8}{|c|}{ Atoms per formula unit } \\
\hline $\mathrm{Si}$ & 6.88 & 6.90 & 6.88 & 6.88 & 6.82 & 6.82 & 2.83 \\
\hline $\mathrm{Ti}$ & 0.15 & 0.14 & 0.13 & 0.15 & 0.17 & 0.15 & 0.16 \\
\hline Al & 1.35 & 1.32 & 1.35 & 1.36 & 1.39 & 1.39 & 1.26 \\
\hline $\mathrm{Fe}^{2+}$ & 2.40 & 2.17 & 2.19 & 2.32 & 2.32 & 2.20 & 1.55 \\
\hline $\mathrm{Fe}^{3+* *}$ & 0.00 & 0.00 & 0.00 & 0.00 & 0.00 & 0.00 & -- \\
\hline $\mathrm{Mn}$ & 0.05 & 0.05 & 0.05 & 0.05 & 0.06 & 0.05 & 0.02 \\
\hline $\mathrm{Mg}$ & 2.29 & 2.52 & 2.49 & 2.34 & 2.34 & 2.52 & 1.08 \\
\hline $\mathrm{Ca}$ & 1.86 & 1.86 & 1.87 & 1.87 & 1.87 & 1.87 & 0.00 \\
\hline $\mathrm{Na}$ & 0.49 & 0.50 & 0.50 & 0.50 & 0.51 & 0.52 & 0.00 \\
\hline $\mathrm{K}$ & 0.16 & 0.16 & 0.16 & 0.16 & 0.18 & 0.17 & 0.92 \\
\hline $\mathrm{Cr}$ & -- & -- & -- & -- & -- & -- & 0.00 \\
\hline $\mathrm{F}$ & -- & -- & -- & -- & -- & -- & 0.06 \\
\hline $\mathrm{Ba}$ & -- & -- & -- & -- & -- & -- & 0.01 \\
\hline $\mathrm{Cl}$ & -- & -- & -- & -- & -- & -- & 0.01 \\
\hline Cation Total & 15.63 & 15.62 & 15.62 & 15.63 & 15.66 & 15.69 & 7.82 \\
\hline $\mathrm{Mg}^{\mathrm{tt}}$ & 0.49 & 0.54 & 0.53 & 0.50 & 0.50 & 0.53 & 0.41 \\
\hline \multicolumn{8}{|c|}{$\begin{array}{l}\text { Weight percent oxide of hornblende and biotite are based on } 24 \text { and } 11 \text { oxygens per formula unit, } \\
\text { respectively. } \\
{ }^{*} \text { Cation total calculated to include } 2 \mathrm{OH}^{-} \text {. } \\
{ }^{\mathrm{t}} \mathrm{All} \text { Fe was measured as } \mathrm{FeO} \text {. } \\
{ }^{* *} \text { Mineral formula calculations for the amphiboles was inconclusive for determination of ferric iron content. } \\
\text { All iron reported as ferrous iron. } \\
\text { ttMg\# }=\mathrm{Mg} /\left(\mathrm{Mg}+\mathrm{Fe}^{2+}\right)\end{array}$} \\
\hline
\end{tabular}


Table B-9. Sample ML 28-6 mineral chemistry.

\begin{tabular}{|c|c|c|c|c|c|c|c|c|c|c|c|c|c|c|c|c|}
\hline \multirow[b]{2}{*}{ Mineral } & \multicolumn{6}{|c|}{ Glen Aulin Endoskarn } & \multicolumn{5}{|c|}{ Calc-silicate Hornfels Xenolith } & \multicolumn{5}{|c|}{ "Hornblende-rich Core } \\
\hline & \multicolumn{2}{|c|}{ Clinopyroxene } & \multicolumn{2}{|c|}{ Garnet } & \multicolumn{2}{|c|}{ Plagioclase } & \multicolumn{2}{|c|}{ Clinopyroxene } & \multicolumn{3}{|c|}{ Plagioclase } & \multicolumn{2}{|c|}{ Hornblende } & \multicolumn{3}{|c|}{ Plagioclase } \\
\hline point & $\begin{array}{c}\text { average } \\
\text { of } 5 \\
\text { grains }\end{array}$ & $\begin{array}{l}\text { standard } \\
\text { deviation }\end{array}$ & 7 & 9 & 8 & 10 & $\begin{array}{c}\text { average } \\
\text { of } 8 \\
\text { grains }\end{array}$ & $\begin{array}{l}\text { standard } \\
\text { deviation }\end{array}$ & 4 & 5 & 6 & $\begin{array}{c}\text { average } \\
\text { of } 5 \\
\text { grains }\end{array}$ & $\begin{array}{l}\text { standard } \\
\text { deviation }\end{array}$ & 1 & 2 & 3 \\
\hline \multicolumn{17}{|c|}{ Weight percent oxide } \\
\hline $\mathrm{SiO}_{2}$ & 52.33 & 0.43 & 37.02 & 37.22 & 59.19 & 59.82 & 52.41 & 0.37 & 59.58 & 56.34 & 60.12 & 39.49 & 0.47 & 52.16 & 52.56 & 47.99 \\
\hline $\mathrm{TiO}_{2}$ & 0.01 & 0.01 & 1.56 & 1.32 & -- & -- & 0.03 & 0.02 & -- & -- & -- & 1.10 & 0.10 & -- & -- & -- \\
\hline $\mathrm{Al}_{2} \mathrm{O}_{3}$ & 0.31 & 0.06 & 9.16 & 9.41 & 26.40 & 25.99 & 0.33 & 0.04 & 25.67 & 27.93 & 25.55 & 13.17 & 0.06 & 31.08 & 30.74 & 34.02 \\
\hline $\mathrm{FeO}^{\text {Total* }}$ & 11.30 & 0.54 & 15.18 & 15.56 & 0.08 & 0.11 & 12.22 & 1.38 & 0.08 & 0.13 & 0.13 & 20.58 & 0.51 & 0.32 & 0.25 & 0.26 \\
\hline $\mathrm{MnO}$ & 0.88 & 0.17 & 0.48 & 0.64 & -- & -- & 0.86 & 0.19 & -- & -- & -- & 0.21 & 0.03 & -- & -- & -- \\
\hline $\mathrm{MgO}$ & 10.58 & 0.30 & 0.11 & 0.09 & -- & -- & 10.01 & 0.76 & -- & -- & -- & 8.01 & 0.37 & -- & -- & -- \\
\hline $\mathrm{CaO}$ & 24.33 & 0.16 & 34.04 & 34.14 & 7.08 & 6.72 & 24.17 & 0.22 & 6.91 & 9.38 & 6.41 & 11.86 & 0.06 & 13.15 & 12.53 & 15.71 \\
\hline $\mathrm{Na}_{2} \mathrm{O}$ & 0.20 & 0.03 & -- & -- & 7.38 & 7.61 & 0.21 & 0.02 & 7.53 & 6.10 & 7.61 & 1.85 & 0.04 & 4.20 & 4.40 & 2.51 \\
\hline $\mathrm{K}_{2} \mathrm{O}$ & 0.00 & 0.00 & -- & -- & 0.25 & 0.27 & 0.00 & 0.00 & 0.16 & 0.18 & 0.18 & 1.93 & 0.06 & 0.08 & 0.08 & 0.03 \\
\hline $\mathrm{Cr}_{2} \mathrm{O}_{3}$ & 0.02 & 0.02 & 0.32 & 0.04 & -- & -- & 0.05 & 0.02 & -- & -- & -- & 0.04 & 0.02 & -- & -- & -- \\
\hline $\mathrm{F}$ & 0.00 & 0.00 & -- & -- & -- & -- & 0.00 & 0.00 & -- & -- & -- & 0.03 & 0.03 & -- & -- & -- \\
\hline Total & 99.95 & 0.18 & $97.88^{t}$ & $98.42^{\mathrm{t}}$ & 100.4 & 100.5 & 100.3 & 0.17 & 99.93 & 100.1 & 100.0 & 98.25 & 0.42 & 101.0 & 100.6 & 100.5 \\
\hline \multicolumn{17}{|c|}{ Atoms per formula unit } \\
\hline $\mathrm{Si}$ & 1.99 & 0.01 & 2.99 & 2.99 & 2.63 & 2.65 & 2.00 & 0.00 & 2.66 & 2.53 & 2.67 & 6.10 & 0.03 & 2.35 & 2.37 & 2.19 \\
\hline $\mathrm{Ti}$ & 0.00 & 0.00 & 0.09 & 0.08 & -- & -- & 0.00 & 0.00 & -- & -- & -- & 0.13 & 0.01 & -- & -- & -- \\
\hline $\mathrm{Al}$ & 0.01 & 0.00 & 0.87 & 0.89 & 1.38 & 1.36 & 0.01 & 0.00 & 1.35 & 1.48 & 1.34 & 2.40 & 0.02 & 1.65 & 1.63 & 1.83 \\
\hline $\mathrm{Fe} 2+$ & 0.36 & 0.02 & 0.09 & 0.08 & 0.00 & 0.00 & 0.39 & 0.05 & 0.00 & 0.01 & 0.01 & 2.66 & 0.08 & 0.01 & 0.01 & 0.01 \\
\hline $\mathrm{Fe} 3+$ & -- & -- & 0.93 & 0.97 & -- & -- & -- & -- & -- & -- & -- & -- & -- & -- & -- & -- \\
\hline $\mathrm{Mn}$ & 0.03 & 0.01 & 0.03 & 0.04 & -- & -- & 0.03 & 0.01 & -- & -- & -- & 0.03 & 0.00 & -- & -- & -- \\
\hline $\mathrm{Mg}$ & 0.60 & 0.02 & 0.01 & 0.01 & -- & -- & 0.57 & 0.04 & -- & -- & -- & 1.84 & 0.08 & -- & -- & -- \\
\hline $\mathrm{Ca}$ & 0.99 & 0.01 & 2.95 & 2.94 & 0.34 & 0.32 & 0.99 & 0.00 & 0.33 & 0.45 & 0.31 & 1.96 & 0.01 & 0.63 & 0.61 & 0.77 \\
\hline $\mathrm{Na}$ & 0.01 & 0.00 & -- & -- & 0.64 & 0.65 & 0.02 & 0.00 & 0.65 & 0.53 & 0.66 & 0.55 & 0.01 & 0.37 & 0.38 & 0.22 \\
\hline $\mathrm{K}$ & 0.00 & 0.00 & -- & -- & 0.01 & 0.02 & 0.00 & 0.00 & 0.01 & 0.01 & 0.01 & 0.38 & 0.01 & 0.01 & 0.01 & 0.00 \\
\hline $\mathrm{Cr}$ & 0.00 & 0.00 & 0.02 & 0.00 & - & -- & 0.00 & 0.00 & -- & -- & - & 0.00 & 0.00 & -- & -- & -- \\
\hline $\mathrm{F}$ & 0.00 & 0.00 & -- & -- & -- & -- & 0.00 & 0.00 & -- & -- & -- & 0.00 & 0.00 & -- & -- & -- \\
\hline $\begin{array}{l}\text { Cation } \\
\text { Total }\end{array}$ & 4.01 & 0.01 & 8 & 8 & 5.00 & 5.00 & 4.00 & 0.00 & 5.00 & 5.00 & 4.99 & 16.05 & 0.02 & 5.01 & 5.01 & 5.01 \\
\hline$\% \mathrm{An}$ & -- & -- & -- & -- & 34.1 & 32.3 & -- & -- & 33.3 & 45.5 & 31.5 & -- & -- & 63.1 & 60.9 & 77.4 \\
\hline$\% A b$ & -- & -- & -- & -- & 64.4 & 66.2 & -- & -- & 65.8 & 53.5 & 67.5 & -- & -- & 36.4 & 38.6 & 22.4 \\
\hline$\% O r$ & -- & -- & -- & -- & 1.50 & 1.50 & -- & -- & 0.90 & 1.00 & 1.00 & -- & -- & 0.50 & 0.50 & 0.20 \\
\hline$\% \mathrm{Di}$ & 62.5 & -- & -- & -- & -- & -- & 59.3 & -- & -- & -- & -- & -- & -- & -- & -- & -- \\
\hline \%Alm & -- & -- & 3.01 & 2.50 & -- & -- & -- & -- & -- & -- & -- & -- & -- & -- & -- & -- \\
\hline$\%$ Pyr & -- & -- & 0.44 & 0.36 & -- & -- & -- & -- & -- & -- & -- & -- & -- & -- & -- & -- \\
\hline
\end{tabular}


Table B-9 (continued)

\begin{tabular}{|c|c|c|c|c|c|c|c|c|c|c|c|c|c|c|c|c|}
\hline \multirow[b]{2}{*}{ Mineral } & \multicolumn{6}{|c|}{ Glen Aulin Endoskarn } & \multicolumn{5}{|c|}{ Calc-silicate Hornfels Xenolith } & \multicolumn{5}{|c|}{ Hornblende-rich Core } \\
\hline & Clinop & yroxene & $\mathrm{G}$ & & & lase & Clinop & roxene & & jioc & & Hornt & lende & & iocl & \\
\hline point & $\begin{array}{c}\text { average } \\
\text { of } 5 \\
\text { grains }\end{array}$ & $\begin{array}{l}\text { standard } \\
\text { deviation }\end{array}$ & 7 & 9 & 8 & 10 & $\begin{array}{c}\text { average } \\
\text { of } 8 \\
\text { grains }\end{array}$ & $\begin{array}{l}\text { standard } \\
\text { deviation }\end{array}$ & 4 & 5 & 6 & $\begin{array}{l}\text { average } \\
\text { of } 5 \\
\text { grains }\end{array}$ & $\begin{array}{l}\text { standard } \\
\text { deviation }\end{array}$ & 1 & 2 & 3 \\
\hline$\%$ Sps & -- & -- & 1.07 & 1.42 & - & -- & -- & -- & -- & - & -- & -- & -- & -- & -- & -- \\
\hline$\% \mathrm{Grs}$ & -- & -- & 43.4 & 43.9 & - & -- & -- & -- & -- & -- & -- & -- & -- & -- & -- & - \\
\hline$\% A d r$ & -- & -- & 46.4 & 47.7 & - & -- & -- & -- & -- & -- & -- & -- & -- & -- & -- & - \\
\hline$\%$ Uvt & -- & -- & 1.01 & 0.13 & - & -- & -- & -- & -- & -- & -- & -- & -- & -- & -- & - \\
\hline
\end{tabular}

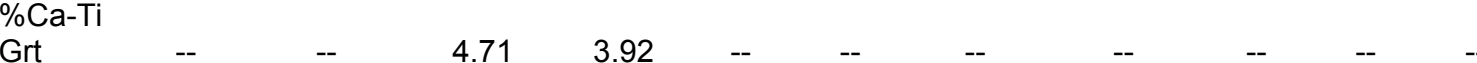

Weight percent oxide data and atoms per formula unit calculated based on $6,8,12$, and 24 oxygens per formula unit for clinopyroxene, feldspar, garnet, and hornblende, respectively.

${ }^{*} \mathrm{All}$ Fe was measured as $\mathrm{FeO}$. $\mathrm{Fe}^{3+}$ was calculated from $\mathrm{FeO}^{\text {total }}$ using stoichiometric charge balance based on 8 cations and 12 oxygens per formula unit.

tLow total weight percent oxide is due to high ferric iron content.

End-members: anorthite (An), albite (Ab), orthoclase (Or), diopside (Di), almandine (Alm), pyrope (Pyr), spessartine (Sps), grossular (Grs), andradite (Adr), uvarolite (Uvt), and Ca-Ti Garnet (Ca-Ti Grt) 
Table B-10. Epidote mineral chemistry from all skarn samples analyzed.

\begin{tabular}{|c|c|c|c|c|c|c|}
\hline $\begin{array}{l}\text { Sample } \\
\text { Point }\end{array}$ & $\begin{array}{c}\text { Exoskarn } \\
\text { ML 28-3 } \\
2\end{array}$ & 1 & $\begin{array}{c}\text { Exoskarn } \\
\text { ML 28-5 } \\
2\end{array}$ & 4 & $\begin{array}{c}\text { Endoskarn } \\
\text { ML 21-3 } \\
1\end{array}$ & $\begin{array}{c}\text { Endoskarn } \\
\text { ML 28-7B } \\
7\end{array}$ \\
\hline \multicolumn{7}{|c|}{ Weight percent oxide } \\
\hline $\mathrm{SiO}_{2}$ & 37.78 & 37.91 & 37.77 & 38.13 & 38.39 & 38.09 \\
\hline $\mathrm{TiO}_{2}$ & 0.10 & 0.06 & 0.10 & 0.15 & 0.04 & 0.06 \\
\hline $\mathrm{Al}_{2} \mathrm{O}_{3}$ & 23.69 & 24.34 & 24.45 & 25.66 & 25.25 & 24.63 \\
\hline $\mathrm{FeO}^{\text {Total* }}$ & 11.92 & 11.17 & 11.11 & 9.63 & 10.43 & 11.10 \\
\hline $\mathrm{MnO}$ & 0.51 & 0.25 & 0.59 & 0.41 & 0.35 & 0.02 \\
\hline $\mathrm{MgO}$ & 0.03 & 0.02 & 0.01 & 0.04 & 0.05 & 0.04 \\
\hline $\mathrm{CaO}$ & 23.01 & 23.45 & 22.90 & 23.33 & 23.40 & 23.58 \\
\hline $\mathrm{Na}_{2} \mathrm{O}$ & 0.01 & 0.00 & 0.02 & 0.02 & 0.00 & 0.02 \\
\hline $\mathrm{K}_{2} \mathrm{O}$ & 0.00 & 0.00 & 0.00 & 0.00 & 0.00 & 0.00 \\
\hline $\mathrm{Cr}_{2} \mathrm{O}_{3}$ & 0.02 & 0.00 & 0.00 & 0.00 & 0.00 & 0.00 \\
\hline Total & 97.06 & 97.21 & 96.97 & 97.37 & 97.92 & 97.54 \\
\hline \multicolumn{7}{|c|}{ Atoms per formula unit } \\
\hline $\mathrm{Si}$ & 3.00 & 3.00 & 2.99 & 2.99 & 3.00 & 3.00 \\
\hline $\mathrm{Ti}$ & 0.01 & 0.00 & 0.01 & 0.01 & 0.00 & 0.00 \\
\hline $\mathrm{Al}$ & 2.22 & 2.27 & 2.28 & 2.37 & 2.33 & 2.28 \\
\hline (A site) & 2.00 & 2.00 & 2.00 & 2.00 & 2.00 & 2.00 \\
\hline (B site) & 0.22 & 0.27 & 0.28 & 0.37 & 0.33 & 0.28 \\
\hline $\mathrm{Fe}^{2+}$ & 0.00 & 0.00 & 0.00 & 0.00 & 0.00 & 0.00 \\
\hline $\mathrm{Fe}^{3+\mathrm{t}}$ & 0.78 & 0.73 & 0.73 & 0.63 & 0.68 & 0.72 \\
\hline $\mathrm{Mn}$ & 0.03 & 0.02 & 0.04 & 0.03 & 0.02 & 0.00 \\
\hline $\mathrm{Mg}$ & 0.00 & 0.00 & 0.00 & 0.00 & 0.01 & 0.00 \\
\hline $\mathrm{Ca}$ & 1.96 & 1.99 & 1.94 & 1.96 & 1.96 & 1.99 \\
\hline $\mathrm{Na}$ & 0.00 & 0.00 & 0.00 & 0.00 & 0.00 & 0.00 \\
\hline $\mathrm{K}$ & 0.00 & 0.00 & 0.00 & 0.00 & 0.00 & 0.00 \\
\hline $\mathrm{Cr}$ & 0.00 & 0.00 & 0.00 & 0.00 & 0.00 & 0.00 \\
\hline Cation Total & 8.00 & 8.00 & 8.00 & 8.00 & 8.00 & 8.00 \\
\hline \%Clinozoisite ${ }^{* *}$ & 20.8 & 26.3 & 26.9 & 36.4 & 31.9 & 28.1 \\
\hline \multicolumn{7}{|c|}{$\begin{array}{l}\text { Weight percent oxide and cations per formula unit were calculated based on } 12.5 \text { oxygens per formula } \\
\text { unit. } \\
{ }^{*} \mathrm{All} F \mathrm{Fe} \text { was measured as } \mathrm{FeO} \text {. } \\
{ }^{\mathrm{t} F \mathrm{Fe}^{3+}} \text { was calculated from } \mathrm{FeO} \text { (Total) for stoichiometric charge balance based on } 12.5 \text { oxygens and } 8 \\
\text { cations per formula unit. } \\
{ }_{\star}^{* * \%} \text { Clinozoisite }=\left[\mathrm{B} \text { site } \mathrm{Al}{ }^{*} 100 /\left(\mathrm{B} \text { site } \mathrm{Al}+\mathrm{Fe}^{3+}+\mathrm{Mn}\right)\right]\end{array}$} \\
\hline
\end{tabular}


Table B-11. Skarn station ML 28 garnet mineral chemistry.

\begin{tabular}{|c|c|c|c|c|c|c|c|c|c|c|}
\hline & \multicolumn{4}{|c|}{$\begin{array}{l}\text { ML 28-2: } 3 \mathrm{~cm} \text { diameter single garnet with } \\
\text { visible zoning, from exoskarn }\end{array}$} & \multicolumn{4}{|c|}{$\begin{array}{c}\text { ML 28-5: medium grained garnets from } \\
\text { exoskarn }\end{array}$} & \multicolumn{2}{|c|}{$\begin{array}{l}\text { ML 28-6: fine-grained } \\
\text { garnets within } \\
\text { endoskarn }\end{array}$} \\
\hline & $\begin{array}{l}\text { Average } \\
\text { of } 30 \\
\text { spots }\end{array}$ & $\begin{array}{l}\text { standard } \\
\text { deviation }\end{array}$ & $\begin{array}{l}\text { Most } \\
\text { aluminous }\end{array}$ & $\begin{array}{l}\text { Most } \\
\text { ferric }\end{array}$ & $\begin{array}{l}\text { Average } \\
\text { of } 5 \text { grains }\end{array}$ & $\begin{array}{l}\text { Standard } \\
\text { deviation }\end{array}$ & $\begin{array}{l}\text { Most } \\
\text { aluminous }\end{array}$ & $\begin{array}{l}\text { Most } \\
\text { ferric }\end{array}$ & $\begin{array}{l}\text { Average } \\
\text { of } 2 \text { grains }\end{array}$ & $\begin{array}{l}\text { Standard } \\
\text { deviation }\end{array}$ \\
\hline \multicolumn{11}{|c|}{ Weight percent oxide } \\
\hline $\mathrm{SiO}_{2}$ & 37.68 & 0.35 & 38.30 & 36.80 & 37.83 & 0.31 & 38.09 & 37.40 & 37.12 & 0.14 \\
\hline $\mathrm{TiO}_{2}$ & 0.72 & 0.42 & 0.47 & 1.41 & 0.47 & 0.50 & 0.12 & 1.32 & 1.44 & 0.17 \\
\hline $\mathrm{Al}_{2} \mathrm{O}_{3}$ & 11.53 & 1.51 & 13.23 & 7.02 & 11.45 & 0.85 & 12.03 & 10.40 & 9.29 & 0.18 \\
\hline $\mathrm{FeO}^{\text {Total* }}$ & 13.62 & 1.83 & 11.65 & 18.46 & 14.37 & 0.62 & 13.71 & 14.51 & 15.37 & 0.27 \\
\hline $\mathrm{MnO}$ & 0.69 & 0.26 & 0.61 & 0.56 & 0.73 & 0.04 & 0.75 & 0.66 & 0.56 & 0.11 \\
\hline $\mathrm{MgO}$ & 0.06 & 0.02 & 0.06 & 0.07 & 0.06 & 0.04 & 0.04 & 0.11 & 0.10 & 0.02 \\
\hline $\mathrm{CaO}$ & 34.16 & 0.57 & 34.52 & 33.44 & 33.71 & 0.31 & 33.67 & 34.13 & 34.09 & 0.07 \\
\hline $\mathrm{Cr}_{2} \mathrm{O}_{3}$ & 0.00 & 0.02 & 0.00 & 0.02 & 0.00 & 0.02 & 0.01 & 0.02 & 0.18 & 0.19 \\
\hline Total $^{\mathrm{t}}$ & 98.46 & 0.33 & 98.85 & 97.76 & 98.63 & 0.34 & 98.43 & 98.54 & 98.15 & 0.39 \\
\hline \multicolumn{11}{|c|}{ Atoms per formula unit } \\
\hline $\mathrm{Si}$ & 3.00 & 0.01 & 3.02 & 3.00 & 3.01 & 0.02 & 3.03 & 2.99 & 2.99 & 0.00 \\
\hline $\mathrm{Ti}$ & 0.04 & 0.03 & 0.03 & 0.09 & 0.03 & 0.03 & 0.01 & 0.08 & 0.09 & 0.01 \\
\hline $\mathrm{Al}$ & 1.08 & 0.13 & 1.23 & 0.68 & 1.07 & 0.07 & 1.13 & 0.98 & 0.88 & 0.01 \\
\hline $\mathrm{Fe}^{2+}$ & 0.08 & 0.03 & 0.08 & 0.12 & 0.11 & 0.02 & 0.11 & 0.09 & 0.08 & 0.01 \\
\hline $\mathrm{Fe}^{3+}$ & 0.83 & 0.12 & 0.68 & 1.14 & 0.85 & 0.04 & 0.80 & 0.88 & 0.95 & 0.02 \\
\hline $\mathrm{Mn}$ & 0.05 & 0.02 & 0.04 & 0.04 & 0.05 & 0.00 & 0.05 & 0.04 & 0.04 & 0.01 \\
\hline $\mathrm{Mg}$ & 0.01 & 0.00 & 0.01 & 0.01 & 0.01 & 0.00 & 0.00 & 0.01 & 0.01 & 0.00 \\
\hline $\mathrm{Ca}$ & 2.91 & 0.03 & 2.91 & 2.93 & 2.87 & 0.03 & 2.87 & 2.92 & 2.94 & 0.01 \\
\hline $\mathrm{Cr}$ & 0.00 & 0.00 & 0.00 & 0.00 & 0.00 & 0.00 & 0.00 & 0.00 & 0.01 & 0.01 \\
\hline Cation Total & 8 & -- & 8 & 8 & 8 & -- & 8 & 8 & 8 & -- \\
\hline$\%$ Alm & 2.52 & 0.88 & 2.73 & 3.84 & 3.56 & 0.59 & 3.69 & 2.87 & 2.76 & 0.36 \\
\hline$\%$ Pyr & 0.22 & 0.08 & 0.24 & 0.27 & 0.22 & 0.14 & 0.16 & 0.42 & 0.40 & 0.06 \\
\hline$\%$ Sps & 1.52 & 0.59 & $\begin{array}{l}0.24 \\
1.35\end{array}$ & 1.25 & 1.62 & 0.09 & 1.67 & 1.46 & 1.25 & 0.24 \\
\hline$\%$ Grs & 52.92 & 6.60 & 60.57 & 33.57 & 52.06 & 3.36 & 55.06 & 48.05 & 43.65 & 0.39 \\
\hline$\% A d r$ & 40.70 & 5.78 & 33.73 & 56.74 & 41.13 & 1.99 & 39.04 & 43.25 & 47.06 & 0.96 \\
\hline$\%$ Uvt & 0.01 & 0.05 & 0.01 & 0.05 & 0.03 & 0.03 & 0.03 & 0.07 & 0.57 & 0.62 \\
\hline$\%$ Ca-Ti Grt & 2.11 & 1.25 & 1.38 & 4.29 & 1.37 & 1.49 & 0.36 & 3.88 & 4.32 & 0.56 \\
\hline \multicolumn{11}{|c|}{$\begin{array}{l}\text { Weight percent oxide data calculated based on } 12 \text { oxygens per formula unit. } \\
{ }^{*} \text { All Fe was measured as FeO. Fe }{ }^{3+} \text { was calculated from FeO }{ }^{\text {total }} \text { using stoichiometric charge balance based on } 8 \text { cations and } 12 \text { oxygens. } \\
\text { tLow total weight percent oxide is due to high ferric iron content. } \\
\text { End-members: almandine (Alm), pyrope (Pyr), spessartine (Sps), grossular (Grs), andradite (Adr), uvarolite (Uvt), and Ca-Ti Garnet (Ca-Ti Grt). }\end{array}$} \\
\hline
\end{tabular}


Table B-12. Feldspar mineral chemistry from granitic pegmatites at stations ML 21 and ML 23.

\begin{tabular}{|c|c|c|c|c|c|c|}
\hline \multirow[b]{3}{*}{ Point } & \multirow{2}{*}{\multicolumn{2}{|c|}{$\begin{array}{l}\text { ML 21-1 } \\
\text { K-feldspar }\end{array}$}} & \multicolumn{4}{|c|}{ ML 23-4 } \\
\hline & & & \multicolumn{2}{|c|}{ K-feldspar } & \multicolumn{2}{|c|}{ Plagioclase } \\
\hline & $\begin{array}{c}\text { Average of } 4 \\
\text { grains }\end{array}$ & $\begin{array}{l}\text { standard } \\
\text { deviation }\end{array}$ & $\begin{array}{c}\text { Average of } 2 \\
\text { grains }\end{array}$ & $\begin{array}{l}\text { standard } \\
\text { deviation }\end{array}$ & $\begin{array}{c}\text { Average of } 5 \\
\text { grains }\end{array}$ & $\begin{array}{l}\text { standard } \\
\text { deviation }\end{array}$ \\
\hline \multicolumn{7}{|c|}{ Weight percent oxide } \\
\hline $\mathrm{SiO}_{2}$ & 64.26 & 0.16 & 64.59 & 0.24 & 61.84 & 0.91 \\
\hline $\mathrm{Al}_{2} \mathrm{O}_{3}$ & 19.09 & 0.17 & 19.07 & 0.13 & 24.81 & 0.64 \\
\hline $\mathrm{FeO}$ & 0.02 & 0.02 & 0.06 & 0.01 & 0.14 & 0.01 \\
\hline $\mathrm{CaO}$ & 0.02 & 0.04 & 0.03 & 0.05 & 5.43 & 0.73 \\
\hline $\mathrm{Na}_{2} \mathrm{O}$ & 1.04 & 0.23 & 1.11 & 0.15 & 8.36 & 0.40 \\
\hline $\mathrm{K}_{2} \mathrm{O}$ & 15.41 & 0.29 & 15.32 & 0.22 & 0.33 & 0.10 \\
\hline Total & 99.84 & 0.26 & 100.20 & 0.00 & 100.92 & 0.19 \\
\hline \multicolumn{7}{|c|}{ Atoms per formula unit } \\
\hline $\mathrm{Si}$ & 2.97 & 0.01 & 2.98 & 0.01 & 2.72 & 0.04 \\
\hline $\mathrm{Al}$ & 1.04 & 0.01 & 1.04 & 0.01 & 1.29 & 0.04 \\
\hline $\mathrm{Fe}^{2+}$ & 0.00 & 0.00 & 0.00 & 0.00 & 0.01 & 0.00 \\
\hline $\mathrm{Ca}$ & 0.00 & 0.00 & 0.00 & 0.00 & 0.26 & 0.04 \\
\hline $\mathrm{Na}$ & 0.09 & 0.02 & 0.10 & 0.01 & 0.71 & 0.03 \\
\hline $\mathrm{K}$ & 0.91 & 0.02 & 0.90 & 0.01 & 0.02 & 0.01 \\
\hline $\begin{array}{l}\text { Cation } \\
\text { Total }\end{array}$ & 5.01 & 0.00 & 5.01 & 0.00 & 5.00 & 0.01 \\
\hline$\% \mathrm{An}^{*}$ & 0.00 & -- & 0.00 & -- & 26.3 & -- \\
\hline$\% A b^{*}$ & 9.00 & -- & 10.0 & -- & 71.7 & -- \\
\hline$\% \mathrm{Or}^{*}$ & 91.0 & -- & 90.0 & -- & 2.02 & -- \\
\hline \multicolumn{7}{|c|}{$\begin{array}{l}\text { Weight percent oxide and cations per formula unit calculated based on } 8 \text { oxygens per feldspar formula } \\
\text { unit. } \\
{ }^{*} \text { End-members: anorthite (An), albite }(A b) \text {, orthoclase (Or) }\end{array}$} \\
\hline
\end{tabular}




\section{APPENDIX C: LIST OF PSEUDOSECTION MINERAL ABBREVIATIONS}

The following is a list of abbreviations used for minerals presented in the pseudosection diagrams.

Table C-2. List of Mineral Abbreviations for Psuedosections

\begin{tabular}{llll}
\hline \hline Mineral & Abbreviation & Mineral & Abbreviation \\
\hline Albite & $\mathrm{Ab}$ & Microcline & Mic \\
Andalusite & And & Mica & Mica \\
Biotite & Bio & Orthopyroxene & Opx \\
Chlorite & $\mathrm{Chl}$ & Osmulite & Osm \\
Cordierite & $\mathrm{Crd}$ & Plagioclase & Pl \\
Clinozoisite & $\mathrm{Cz}$ & Quartz & Qtz \\
Fayalite & $\mathrm{Fa}$ & Sanadine & San \\
Fe-anthophyllite & Fanth & Sillimanite & Sill \\
Garnet & $\mathrm{Gt}$ & Staurolite & St \\
Kyanite & $\mathrm{Ky}$ & - & -- \\
\hline
\end{tabular}

